\title{
Sequence completed - palynological investigations on Lateglacial/Early Holocene environmental changes recorded in sequentially laminated lacustrine sediments of the Nahe palaeolake in Schleswig-Holstein, Germany.
}

Sascha Krüger ${ }^{\mathrm{a}, \mathrm{b}}$, Morten Fischer Mortensen ${ }^{\mathrm{c}} \&$ Walter Dörfler ${ }^{\mathrm{b}}$

${ }^{a}$ Centre for Baltic and Scandinavian Archaeology, Stiftung Schleswig-Holsteinische Landesmuseen, Schloss Gottorf, D-24837 Schleswig, Germany. E-mail: sascha.krueger@zbsa.eu

${ }^{b}$ Institute of Prehistoric and Protohistoric Archaeology, Christian-Albrechts University Kiel, JohannaMestorf-Straße, D-24106 Kiel, Germany.

${ }^{c}$ The National Museum of Denmark, Environmental Archaeology and Material Sciences, I.C. Modewegsvej, 2800 Kongens Lyngby, Denmark.

\begin{abstract}
The exploration of Lateglacial vegetation history in Schleswig-Holstein is elaborate and comprehensive. Despite being one of the most studied areas, regarding to the Lateglacial, no biostratigraphy covering the complete Lateglacial and Early Holocene periods without hiatus have so far been recovered. In this paper we present a biostratigraphy of the Nahe palaeolake, therewith intending to deal with this desideratum.

The special strength of the presented sequence is expressed in the fact that these are the only palynologically investigated sequentially annual laminated limnic sediments of the Lateglacial in Schleswig-Holstein. These laminated sediments, as well as radiocarbon dating of botanical macrofossils and three geochemically confirmed cryptotephra layers (Laacher See Tephra, Vedde Ash and Saksunarvatn Ash), provide excellent chronological control and allow for a Europe-wide correlation. Particularly important is a complete discussion of the vegetation history and the spatial proximity to Late Palaeolithic sites, which renders it possible to evaluate potential humanenvironment-interaction long before classical palynological human indicators occur.
\end{abstract}

\section{Introduction}

During the Lateglacial, the area of modern Schleswig-Holstein (Germany) constituted part of a corridor directed towards Scandinavia, thus assuming an essential function in the north-facing colonization processes by flora, fauna and humans. As a result, the interest into palaeoenvironmental research was continuously growing since the 1930s. This was further amplified by the 
excellent preservation conditions of several Palaeolithic sites, which from early days paved the way for close interlinking of vegetation history and archaeological research (Aletsee 1959; Averdieck et al. 1972; Bokelmann et al. 1983; Hallik and Grube 1954; Schütrumpf 1935; 1936; 1943; 1958; Tidelski 1960; Usinger 1975; 1978b; 1981a; 1981b; 1981c; 1985; 1998; 2004; Usinger and Wolf 1982).

A comprehensive study of the hitherto presented pollen profiles, however, reveals that various obstacles arose which could hardly be overcome. One of those still is that the pollenanalytical investigations of different time periods are bound to the geological tripartition of Schleswig-Holstein. This implies that suitable palynological archives for the Lateglacial are mainly located within the younger moraine area in the east (fig 1). Here, the basins and depressions of the lakes and bogs mainly originate from dead ice and subglacial meltwater streams (Woldstedt 1954). Melting of buried dead ice often resulted in turbations and rearrangement of Lateglacial sediments from important Holocene key sites in Schleswig-Holstein such as Lake Belau and Lake Poggensee (pers. com. I. Feeser). Unfortunately, this deprives the often even annually laminated Lateglacial depositions of their usefulness for an investigation.

In addition, a widespread hiatus in sediment sequences especially in the transition between the late Allerød and Dryas 3 periods are demonstrated at many localities. Usinger (1981a) was able to explain this by climatically caused lake level fluctuations and erosion processes.

Since many of the sites were studied during the early days of pollen analysis it is worth mentioning the recent methodological progress within palynology. The pioneering nature of the research has often prevented difficult pollen types such as Juniperus (juniper) and Populus (poplar) from being recognized. Also the separation of birch pollen types - which is crucial for the reconstruction of the Lateglacial vegetation history - only became a standard in Schleswig-Holstein with investigations by Hartmut Usinger (Usinger 1975; 1981b; 1981c; Usinger and Wolf 1982).

Another challenge is the ambiguity in biostratigraphical terminology on a geographically large scale that are only gradually being overcome (De Klerk 2004a; Donner 1995; Hoek 1997; 2009; Krüger \& Damrath 2019; Litt et al. 2007; Mangerud et al. 1974; Menke 1968; Usinger 1985). The comprehensive research results from Schleswig-Holstein could just marginally contribute to the discussion of terminology, as radiocarbon dates were rarely used to ensure a reliable chronological frame. Also a contribution to the Lateglacial tephrochronological framework is missing. Hence, there is a lack of pollen profiles that can be directly correlated with the existing event stratigraphy (Björck et al. 1998; Blockley et al. 2014; Jones et al. 2018; Rasmussen et al. 2006).

Despite all these obstacles, the previous work has substantially contributed to the understanding of Lateglacial vegetation history. 
The same applies also to the interlinking of Lateglacial archaeology and palynology in SchleswigHolstein. This interlinking has so far been based exclusively on a stratigraphic correlation. Schütrumpf (1936) reports that archaeological finds from the Meiendorf site were embedded in sapropel. By determining the pollen spectrum of the corresponding layer, archaeological cultures were related to the development of vegetation in order to achieve a chronological classification of finds. The same methodology was applied to other sites in the Ahrensburg tunnel valley (Schütrumpf 1935; 1943; 1958).

Even recent sites in Schleswig-Holstein were dated by pollen stratigraphy (Usinger 1998) presenting a direct stratigraphic link between vegetation history and archaeology. However, the focus has never been on investigating human influence on the surrounding environment by way of applying palynology on- or near-site, likely because the classical human indicators in pollen records are associated with the Neolithic (Behre 1981; 1986; Firbas 1937; Iversen 1941). Nevertheless, there are several studies that discuss both Early Holocene and Lateglacial human indicators (Bos and Janssen 1996; Bos and Urz 2003; Bos et al. 2005; Edwards 1990; Kaplan et al. 2016; Mortensen et al. 2014b; Selsing 2018).

Consequently, there is a research desideratum with regard to a Lateglacial archaeological site that has been palynologically investigated. It still remains unclear how Late Palaeolithic and Early Mesolithic human activity is reflected in the palynological record.

After several years of collecting surface finds, the Archaeological State Department SchleswigHolstein conducted excavations in Nahe (Kr. Segeberg/ Germany). Here, on the former shore of a Lateglacial incision lake (Nahe palaeolake, NAH), faunal remains including more than $80 \%$ reindeer (Rangifer tarandus) were found dating to the Dryas 3 period. In combination with the lithic artefacts the finds can be assigned to the Ahrensburgian. The excavated area is interpreted as a refuse zone of a nearby camp site, which is assumed to lay on a slight elevation (Wild 2017). The investigation was accompanied by numerous drillings that were carried out by Hartmut Usinger. The examination of 68 sediment sequences revealed laminated sediments in the deeper part of the basin - approximately $100 \mathrm{~m}$ from the assumed refuse zone. Here, another coring campaign was conducted in October 2017. The analysis yielded a complete Lateglacial to Early Holocene sediment sequence with partial lamination and extraordinary preservation conditions for botanical macrofossils and pollen including the opportunity of integration into the archaeological context (Dreibrodt et al., in prep.). A targeted search for cryptotephra revealed three layers of non-visible ash beds allowing for direct correlation with European key sites via event stratigraphy (Dreibrodt et al., in prep.; Krüger \& van den Bogaard, in prep.). Consequently, we here present the results of the palynological and macro-botanical investigations of the sediment sequence from the Nahe palaeolake. 
Aims:

1. To present and discuss the first complete Lateglacial/ Early Holocene pollen profile from SchleswigHolstein (supported by macrofossil data).

2. To investigate the temporal scale of phases of environmental transformations.

3. To compare biostratigraphic transformations (Dryas 1-Allerød / Dryas 3-Preboreal).

4. To correlate the site with further European key sites.

5. To consider different causes for the recorded charcoal particle concentrations.

\section{Study site}

The Nahe palaeolake is located in Schleswig-Holstein about $30 \mathrm{~km}$ north of Hamburg (Germany). The basin of the former lake was part of a larger glacial lake system and is separated from further elongated incision lakes by two narrow sand ridges to the northwest and southeast (Smed 1998; Woldstedt 1935; 1954). To the southeast, Lake Itzstedt is the water-bearing remnant of the lake system.

The size of the palaeolake surface was about 16 ha during the Lateglacial. The terrestrialisation process was completed in the course of the late Holocene. Today, the river Rönne flows in the centre of the still existing depression and thereby follows the course of the former lake in north western direction before turning southwards and draining off into the river Alster (fig. 2). The area is used as pasture and partly forested by alder, birch and willow today. The coring location is situated in the formerly deepest part of the incision lake $\left(53^{\circ} 48,711^{\prime} \mathrm{N}, 10^{\circ} 8,082^{\prime} \mathrm{E}\right)$. The position was selected on the basis of preceding extensive survey corings in 2003 and 2004 by Hartmut Usinger.

The Nahe palaeolake is embedded in a well-known archaeological find area. In this respect, the southeastern shore of the former lake on the narrow ridge to Lake Itzstedt and the associated flat moraine are of interest for this study. Here, the top of the moraine was intensely surveyed by Thomas Poelmann for the last 30 years. These surveys yielded more than 12,000 lithics that have predominantly been assigned to the Ahrensburgian as well as Hamburgian techno-complexes (Weber et al. 2011).

Three separate concentrations at an elevated position suggest the location of former camp sites. Succeeding excavations in the palaeo-shoreline were carried out by Ingo Clausen of the Archaeological State Department Schleswig-Holstein. These investigations revealed further stone artefacts as well as faunal remains (Weber et al. 2011; Wild 2017). 
Faunal remains have been investigated by Wild (2017) and radiocarbon ages of bones and antler suggest a temporal classification into the Dryas 3 period and partly into the early Preboreal period. For that time, a ford situation can be reconstructed at the south-eastern end of the lake in the form of a shallow water area above a sand ridge, situated at the foot of the morain. The composition of the finds, antler technology as well as the topographical situation reflect a comparable situation as reconstructed for the Ahrensburg tunnel valley, located only $18 \mathrm{~km}$ to the south (Rust 1943; Rust and Gripp 1937).

\section{Materials and Methods}

\subsection{Field methods and sampling}

The coring took place in October 2017. A modified Livingston piston corer (Mingram et al. 2007) - the so called Usinger-corer - was used to extract the sediment cores. Two overlapping sediment sequences with a diameter of $80 \mathrm{~mm}$ and a length of $16 \mathrm{~m}$ have been reached by drilling. Each 1-msegment was cut longitudinally, stored in PVC-liners and processed at the Institute for Pre- and Protohistoric Archaeology in Kiel, Germany. In order to connect the core sequences a series of distinct layers and stratigraphic marker horizons have been defined in the parallel cores. In this way, a composite core was constructed, representing a continuous record avoiding gaps (Dörfler et al. 2012).

The interdisciplinary approach of the study required that the results of different methods could be correlated across depths. Therefore, a grid of $5 \mathrm{~mm}$ step size was created spanning the lower $5 \mathrm{~m}$ of the sequence. Each sample has been labelled according to consecutive numbers (953 potential samples in total, $11.10 m-15.89 m$ below the surface). A preliminary examination with 16 pollen samples determined the focus sequence for the analyses. The scope of the analyses is set on the sequence between sample 330 (12.745-12.750 m, 10,030 cal yr BP) and 907 (15.605-15.610 m, $\sim 14.780$ cal yr BP).

\subsection{Stratigraphy and loss on ignition}

Subsequent to glacial gravel and sand at $15.78 \mathrm{~m}$ below the surface banded clay has been deposited up to $15.42 \mathrm{~m}$ with inserted layers of sand. This is overlaid by a sequence of clayey gyttja up to 15.1 $\mathrm{m}$, fine varved gyttja up to $14.48 \mathrm{~m}$ and sandy gyttja up to $14.19 \mathrm{~m}$. The transition from Lateglacial to Holocene sediments is reflected in an increasing organic sediment content that corresponds to an increasingly darker colouring of the detrital gyttja up to $13.8 \mathrm{~m}$ below the surface. Detrital gyttja interspersed by calcareous gyttja layers has been deposited up to $1.6 \mathrm{~m}$, where fen peat overlays the sequence. The visual sediment transitions are exclusively gradual. Apart from sand layers at the bottom of the sequence no sharp boundaries have been observed. 
Loss on ignition (LOI) was determined at $550^{\circ}$ and $950^{\circ} \mathrm{C}$ using a thermogravimetric analyser (ELTRA TGA Thermostep). Therein, sample sizes of $2 \mathrm{~cm}^{3}$ sediment were proceeded following Heiri et al. (2001).

\subsection{Pollen analysis}

Pollen sampling was continuously carried out in $5 \mathrm{~mm}$ steps throughout the determined focus sequence. Samples for pollen analysis were chosen for every centimetre (i.e. every second subsample taken) through most of the studied sequence. In some levels samples of every fourth centimetre were analysed. The halves of the core stored in the PVC-liners were cut into $5 \mathrm{~mm}$ slices. The resulting quarters were sampled using sterile prepared disposable syringes. The volume of the individual samples is between $1-1.9 \mathrm{~cm}^{3}$ sediment. Sample preparation was carried out according to standard techniques (Erdtman 1960; Fægri and Iversen 1989) including HF (60\%) treatment of samples with high clay and silt contents. Lycopodium spore tablets were added to enable the calculation of pollen concentrations (Stockmarr 1971). Pollen counting was performed at a total magnification of $x 400$ for routine counting and $x 1000$ for critical objects using a Nikon Eclipse 50i microscope. A pollen sum of at least 550 TTP (total terrestrial pollen) per sample was achieved. A total of 191 samples were counted. Cyperaceae were excluded from the TTP sum due to the high amount of locally produced pollen.

Pollen identification mainly followed Beug (2004) as well as Moore et al. (1991). The reference collection at the Institute of Pre- and Protohistoric Archaeology in Kiel was consulted. As supplement to the macrofossil data Betula pollen were measured in order to differentiate between a Betula nana-type and a B. pubescens-type (Beug 2004). Therefore, a fixed threshold of $21.5 \mu \mathrm{m}$ was applied following Birks (1968), Karlsdóttir et al. (2007), Kolstrup (1982), Krüger and Damrath (2019), Mortensen et al. (2011) and Usinger (1975; 1978a; 1981b; 1982). Pollen of termophilous taxa such as Alnus, Quercus, Ulmus, Tilia, Carpinus, Corylus, Fagus, Hedera and Ilex aquifolium are regarded as rebedded if appearing in a Lateglacial context.

Infrequent appearing pollen clumps where counted as one pollen of the respective type. Further, regularly occurring non-pollen palynomorphs (NPPs) were recorded following Van Geel (1976). Charcoal identification was made based on morphological characteristics such as sharp breaking edges (including a halo effect at phase contrast setting around these), angular, opaque usually planar and often asymmetric shape and a deep black colour (Krüger et al. 2017; Patterson et al. 1987; Tipping 1996). The recording also included a classification of three size classes (10-50 $\mu \mathrm{m}$, 50-100 $\mu \mathrm{m},>100 \mu \mathrm{m})$. 
Zone boundaries were set according to substantial changes in taxa representation following Hedberg (1976) and additionally on loss on ignition. A cluster analysis (CONISS, broken stick model) using the Tilia software (Grimm 2000, vers. 1.7.16) was applied to cross-check general major boundaries. Subzones were defined by visual assessment. The results of pollen ratios and concentration were visualized using the CountPol software (I. Feeser, Kiel University) as well as Inkscape (vers. 0.92.4) where zone boundaries have been drawn and minor changes have been made. The terminology used is described further below (cf. 4.1).

\subsection{Macrofossil analysis}

The standard processing of fossil pollen samples includes the extraction of botanical macrofossils from the sediment samples in preparation. After removing humic acids and a deflocculation with 5$10 \% \mathrm{KOH}$, a sieve with $200 \mu \mathrm{m}$ mesh size was used to remove coarse particles (Fægri and Iversen 1989). In this way, macrofossils were extracted from each pollen sample resulting in 191 samples. The comparatively small volume of the individual samples of between 1-1.9 $\mathrm{cm}^{3}$ sediment results in only a few macrofossils being obtained. As they occur only sporadically, raw counts are given in the results.

Macrofossils were identified and counted at 10-40x magnification using an Olympus SZ51 binocular. Standard identification guides (Bejerinck 1976; Cappers and Bekker 2013) and the reference collection at the Institute of Pre- and Protohistoric Archaeology at Kiel University were consulted.

\section{$3.5{ }^{14} \mathrm{C}$ dating and age-depth model}

The sediment sequence has been subject to an intense search for datable organic material during the subsampling process for pollen analysis. Twelve levels containing terrestrial plant macrofossils were AMS ${ }^{14} \mathrm{C}$ dated (further including two true replicates) at the laboratories in Groningen (GrM) and Kiel (KIA). Additionally, a targeted search for cryptotephra revealed three event horizons that have been used as further dates (Dreibrodt et al., in prep.; Krüger \& van den Bogaard, in prep.). The sediment sequence between 14.93 and $14.45 \mathrm{~m}$ appeared laminated and has hence been subject to varve counting. As the only datable macrofossil from the lower section of the sequence gave a much too old result, additional pollen analytical features were used as chronological markers. The compiled data contributes to the age-depth model used here that has been described by Dreibrodt et al. (in prep.). 


\section{Results and Discussion}

The scope of the analyses is set on the sequence between sample $330(12.745-12.750 \mathrm{~m} / \sim 8,980 \mathrm{cal}$ yr BP) and 920 (15.665-15.670 m/ 14,950 cal yr BP) covering lacustrine sediments deposited between the end of the Pleniglacial and the Early Holocene. The diagram was divided into seven pollen assemblage zones (PAZ; NAH-1 to NAH-7), which further included 18 subzones. The general development in the pollen record is described in supplementary data table 1 . The pollen diagram showing percentage values calculated on TTP excluding Cyperaceae are shown in figure 3 including the results of LOI. A simplified concentration diagram is given in figure $4 a$ and $b$.

The spectrum of recorded macrofossils is limited by the small sample volume and different sedimentation conditions. The results are given in supplementary data table 2 and included in the discussion below.

\section{1 biostratigraphical terminology and zonation of the Lateglacial}

Zonation and setting of biostratigraphical boundaries (or transitions) are dependent on multiple factors and are time transgressive across different landscapes. However, they represent significant biostratigraphic equivalents that can be used as marker horizons (Firbas 1954; Menke 1968). With regard to biostratigraphic correlation Schleswig-Holstein forms a bridge between central European and Scandinavian pollen records (Litt and Stebich 1999). Nevertheless, in these areas biostratigraphic designations were used in different ways. Considering the bridging function of the presented record it is crucial to briefly discuss the terms in use, without temporal contextualization or absolute chronological analogy.

For the first phase of the Lateglacial the local term Meiendorf was introduced by Menke (in Bock et al. 1985; 1968) in Schleswig-Holstein, which is also applied in the present study. The separation from the Pleniglacial is linked to a significant increase in Artemisia values as well as characteristic species as Hippophaë, Helianthemum, Selaginella selaginoides and an increase in overall AP (arboreal pollen) percentages (De Klerk 2008b; Hoek 1997; Iversen 1954; Menke 1968; Van der Hammen 1951; Van Geel 1989). Following the results of Krüger and Damrath (2019) Meiendorf as biostratigraphic expression equals the term Bølling (Iversen 1942) in classical Danish research context. Therefore, and to further avoid confusion of terms, we refrain from using the term Bölling/Bølling as designation for the first phase of the later following Allerød period (Usinger 1981c; 1985). The differentiation between the previous Meiendorf period and the successive Dryas-1 period is determined by an increase in NAP. Regarding terminology, Arabic numbers have proven to be useful in order to avoid confusion with terms as Oldest, Older or Younger. The term Dryas-1 has been 
introduced by Nilsson (1960) and originally designated the Oldest Dryas sensu Iversen (1942) or the Earliest Dryas sensu Kolstrup (1982) - terms for the onset of the Lateglacial in Danish and Swedish research context prior to the work by Mortensen et al. (2011). Dryas-1 in the present study equals Älteste Tundrenzeit sensu Menke (1968) including indicative pollen types as Helianthemum sp., Selaginella selaginoides or Thalictrum sp., strong decrease in Hippophaë sp. and an increase in general NAP (non-arboreal pollen) percentages, separating the Meiendorf period from the successive Allerød period.

The term Allerød period is applied here in the classical connotation. The decisive factor in this respect is the spread of birch trees (Hartz and Milthers 1901). As this can never be linked to a rapid increase in Betula pubescens-type pollen percentages alone the presence of macrofossils is fundamental (Birks and Birks 2000; Schütrumpf 1943).

Benefitting from the high resolution of the record, the Allerød period is divided into multiple subperiods. These further include two separate phases of recurrent Betula pubescens-type pollen percentages and increasing NAP percentages. The first of these declining phases succeeds the rapid spread of birch trees at the onset of the Allerød period, which was formerly referred to as Bölling in German research context (Litt and Stebich 1999; Usinger 1985). The short-term increase in pollen of heliophilous species - the same that had a considerable proportion of the Dryas-1 pollen-flora - led to the designation Dryas-2 period for this first intra Allerød oscillation.

The second of these internal Allerød declining phases precedes the Laacher See Tephra. The stratigraphical context in combination with palynological characteristics leads to the designation Gerzensee-Oscillation (Andersen et al. 2000; Björck et al. 1998; Lotter et al. 2000; Mortensen et al. 2011). Even if this is often referred to as intra-Allerød-cold-period (IACP), this might be a misleading term here with regard to the Dryas-2 that would hence be another IACP.

The stadial-period separating the Allerød period from the onset of the Holocene is widely known as Younger Dryas period. This is in accordance with the majority of palynological records across central and northern Europe and is characterized by an increase in Betula nana-type pollen percentages and NAP percentages as well as a decrease in AP percentages (Birks and Birks 2008; Hoek 1997; Iversen 1942; 1954; Jahns 2000; Litt et al. 2007; Litt and Stebich 1999; Mangerud et al. 1984; Merkt and Müller 1999; Mortensen et al. 2011; 2014b; Neugebauer et al. 2012; Overbeck 1975; Wulff et al. 2013). Nevertheless, in order to maintain the line of reasoning, the term Dryas-3 is used here following Nilsson (1960) and Usinger (1978a). 


\section{2 environmental synthesis}

The environmental synthesis comprises the discussion of palynological, macrofossil and sedimentological data based on the division according to pollen assemblage zones (PAZs). The brackets following the PAZ designation contain an assignment of the PAZ to biostratigraphy as defined above, followed by the depth below the ground surface and calibrated ages BP. In this context, it should be emphasized that the given ages do not represent absolute dates of the biostratigraphic units, but represent temporal estimates of the respective depths.

NAH-1: (cf. Pleniglacial, 15.695 to 15.550 m) 14,950 to 14,510 cal yr BP.

During the termination of the Pleniglacial, the surroundings of the basin were subject to extensive erosional processes. Based on the position relative to the former ice margin and push moraines it can be discerned that besides permafrost, solifluction and aeolian activity also extensive glacio-fluvial and meltwater activity affected the area.

These activities are reflected in e.g. sand layers of different thickness that can be regarded as event horizons intermitting varved clay in the lowermost section of the sediment sequence. These layers consist of homogeneous medium to coarse grained sand bands and are reflected as distinct and synchronous minima in organic and $\mathrm{CaCO}_{3}$ sediment content. They can be associated with clasts that were probably introduced into the channel-like basin by collapsing banks that in turn remained extremely unstable due to very sparse or a lack of vegetation cover (Birks and Birks 2008; Shaw 1975). This is concordant with a generally low concentration of predominantly less than 1000 pollen and spores per $\mathrm{cm}^{3}$ sediment and high proportions of corroded pollen grains.

Indications of various erosional processes are also documented by dinoflagellate cysts (HdV-704), the Glomus-type (cf. G. fasciculatum; HdV-207), high charcoal particle concentrations and high amounts of corroded pollen grains as well as rebedded pollen grains of thermophilous taxa. Here, especially dinoflagellate cysts are a sign of persistent melt water activity and secondary deposition as they are originally part of the marine fauna (Bakker and van Smeerdijk 1982; Lotter 1999). However, Pinus pollen is the predominant pollen type of the assemblage zone with values partially significantly above $50 \%$. These high quantities can probably be attributed to increased aeolian activity and thus long-distance transport. Proportions of these high counts could also be redeposited as the abundance of thermophilous taxa suggests (Hoek et al. 1999). This assumption would be consistent with the high number of almost exclusively recorded single aerial sacks/sacci (Odgaard 1994).

With regard to the size also Betula pubescens-type pollen are recorded in increased abundances that cannot be ignored. In the absence of macrofossils and lacking evidence of the tree birch north of the 
Bavarian Prealps and northwest of Hungary during the terminating High Glacial period (Bennett et al. 1991; Tzedakis et al. 2013; Willis et al. 2000), presence of tree-sized Betula seems rather unlikely. Redeposition and long-distance flight are again plausible sources (Hjelmroos 1991; Hjelmroos 1992; Wallin et al. 1991).

Minor quantities of Betula nana-type pollen, Salix sp. and Juniperus sp. may be reflections of the vegetation on dry raw soils of the surrounding area. However, it is rather probable that these dwarf shrubs - if actually present - were scattered and did not form comprehensive populations. The pollen spectrum of NAH-1 further includes light-demanding families and species of open partially humid habitats as Poaceae, Caryophyllaceae, Cyperaceae, Polypodiaceae and Helianthemum sp. In general, it can therefore be assumed that a sparse and rather barren local vegetation predominated, with low grasses, herbs and dwarf shrubs. It is also plausible that raw soils were part of the landscape - exposed to the energy of various erosion processes.

However, the pollen composition of NAH-1 is characteristic for records of mineroclastic infills from lakes of various origin, where the pollen signal is masked by turbations and redeposition (Leroy et al. 2000; Litt and Stebich 1999). It cannot be excluded that all material originated from a pure secondary pollen record, impairing the interpretation (Iversen 1942).

NAH-2a1: (cf. Meiendorf period, 15.550 to 15.455 m) 14,510 to 14,260 cal yr BP. The continuous erosional activities during NAH-2a1 are displayed in various proxies. Still, major erosional processes occurred resulting in the deposition of homogeneous medium to coarse grained sand bands, presumably reflecting further clastic input into the lake basin (e.g. spring melting). They are again correlated with distinct synchronous minima in organic and $\mathrm{CaCO}_{3}$ sediment content. $\mathrm{A}$ pollen sample taken from a sand layer (15.465) reveals an intermittent interruption of various pollen curves. A recorded peak in Corylus values and several finds of thermophilous Ilex aquifolium pollen unveil that the spectrum must be considered out of sequence. This strengthens the assumption that the sand layers are to be classified as pure redeposited event layers. However, increased meltwater activity during NAH-2a1 is indicated by different thermophilous taxa (regarded as secondarily deposited), high numbers of corroded pollen grains and especially maximum values of dinoflagellate cysts (HdV-704) (Bakker and van Smeerdijk 1982; Lotter 1999). This is in line with the general strengthened ablation of glaciers due to the temperature rise of the temporally corresponding GI-1e, to which the onset of the Lateglacial is ascribed (Björck et al. 1998; Hoek 2008; Weaver et al. 2003).

Within the assemblage zone, a succession of colony-forming green algae can be observed. A first maximum of Botryococcus values precedes an increase of Pediastrum values. Some of the associated species are considered to be lacustrine pioneers because of their ability to bind nitrogen in initially 
nitrogen-poor waters and thus create the basis for other aquatic organisms (Van Geel et al. 1984). The gradual increase in the degree of eutrophication is also expressed in the presence of Filinia longiseta-type rotifers (HdV-603), indicative for clear water conditions (pers. com. M. WieckowskaLüth). Clearly, their continuous presence would imply a climatic amelioration that would be in line with the rapid warming of the Meiendorf period (Koste 1980; Litt and Stebich 1999; Ruttner-Kolisko 1980). Aquatic species react more directly to climatic events having a very short reproduction cycle (Iversen 1954; Lotter 2001; Wright 1984). Here, the spread and diversification of aquatic organisms is clearly associated with the onset of the Lateglacial.

The minor increase in overall pollen concentration is linked to the spread of heliophilous herbs and grasses within the assemblage zone. Still, Pinus pollen is the dominant pollen type showing a rapid decrease from 50 to $20 \%$. However, this is not reflected in the pollen concentration where values remain stable. The preservation conditions towards the end of the assemblage zone are rapidly improving, resulting in a much higher TTP sum including a diversification of recorded pollen types. This is accompanied by an increase in Betula pubescens-type and B. nana-type pollen. It can be assumed that the overall input in Pinus pollen presumably remained stable - prevailing a mixture of long-distance flight and redeposition - and resulting in stable concentrations, whereas the percentage diagram here depicts a calculation effect.

The synchronous rise in percentages of heliophilous grasses and herbs (Artemisia sp., Hippophaë sp., Bidens-type, Selaginella selaginiodes, Chenopodiaceae, Caryophyllaceae, Asteraceae) at the beginning of NAH-2a1 is concordant with the biostratigraphical characteristics of the onset of the Lateglacial throughout northern central Europe (De Klerk 2002; De Klerk et al. 2008a; Hoek 1997; Iversen 1954; Menke 1968; Merkt and Müller 1999; Usinger 1985; Van der Hammen 1951; Van Geel 1989).

It is likely that an increase in summer temperatures or longer summer periods led to the spread of various aquatic, telmatic and terrestrial species (De Klerk 2008a). Thereby, insufficient soil formation is a potential limiting factor for the spread of the upland vegetation. The upland vegetation in turn was dominated by heliophilous grasses and herbs. At favourable probably sheltered stands, dwarf shrubs as Betula nana and Juniperus sp. flourished but the general appearance of the vegetation remained rather barren. Salix polaris is represented in the macrofossil record and was therefore certainly part of the first vascular plants colonizing raw formerly glaciated soils in the surrounding area. The light seeds are distributed very easily by wind and thus, as well as by the low habitat requirements, the plant has an advantage in the opening up of habitats released by the glaciers (Bennike and Jensen 1995).

Biostratigraphical characteristics of the Lateglacial were met before the termination of main erosion events (sand layers) in the area. This is consistent insofar as the upland vegetation was probably able 
to consolidate the surrounding slopes and the soil only by the end of the PAZ. Hippophaë sp., with its widely branched root system, presumably made an essential contribution to the soil stabilization (Heinisch 1952; Skogen 1972). Whether there were still exposed unvegetated areas in the landscape cannot be clarified but remains likely.

NAH-2a2 (cf. Meiendorf period, 15.455 to $15.335 \mathrm{~m}$ ) 14,260 to 14,080 cal yr BP.

A change to a clayey gyttja as a potential mixture of glacial outflow material and metabolic products of aquatic organisms as well as external organic input prove continuous meltwater activity during NAH-2a2. Nevertheless, the absence of massive mineroclastic layers reveal calmer conditions within and around the incision lake. This is consistent with continued detection but marked decreases in values of dinoflagellate cysts (HdV-704), pollen of thermophilous taxa and charcoal concentration. Although erosion continued to play a role, the increasing coverage of soils by tundra vegetation is certainly responsible for a weakening of rearrangement and in particular solifluction, resulting in a decrease of all erosion indicators.

Organic and $\mathrm{CaCO}_{3}$ sediment contents double within the assemblage zone. It is likely that rising temperatures stimulated the growth of algae (especially Pediastrum sp.) to a degree that resulted in increased precipitation of $\mathrm{CaCO}_{3}$ (Chrobok 1986). Algae growth was further amplified by the clear water conditions in the basin, as potentially indicated by the presence of the Filinia longiseta-type (HdV-603).

The pollen concentration rises from about 500 to more than 1000 grains per $\mathrm{cm}^{3}$ sediment. This is a result of a slight increase in AP and a strong increase in NAP, of which Poaceae and Helianthemum sp. have significant shares.

Concentrations of extra-local allochthonous elements such as Pinus sp. and Betula pubescens-type pollen (Janssen 1972) remain rather stable. Still, a local presence of Pinus sp. and Betula pubescens is rather unlikely, but especially the geographical range of Betula pubescens shifted northwards to western Pomerania (De Klerk 2004b; De Klerk et al. 2001) or mid Germany and the southern Netherlands (Hoek et al. 1999; Merkt and Müller 1999) in the course of the early Lateglacial. The values of Hippophaë sp. (cf. rhamnoides) pollen reach their maximum ( 4\%) within this assemblage zone. As the species is insect pollinated and a low pollen producer comprehensive local stands can be assumed by even low percentage values (De Klerk et al. 2008a; Firbas 1934; 1949; Overbeck 1975; Søgaard et al. 2018). Local presence of Hippophaë sp. had been assumed at different sites in northern central Europe at comparable values: Stellmoor 2.1\% - Usinger unpubl.; Glüsing 1\% - Menke (1968); Slotseng 2\% - Mortensen et al. (2011); Hämelsee 1\% - Merkt and Müller (1999); Reinberg basin $\sim 6 \%$ - De Klerk et al. (2008a) (fig. 5). Hippophaë sp. presumably grew on the sandy slopes close to the lake together with Betula nana, Juniperus and Salix sp. 
Marked increases in Poaceae, Helianthemum sp. and a maximum in Artemisia pollen values within this assemblage zone are apparent. The spread of further heliophilous and unpretentious herbs such as Caryophyllaceae, Rosaceae, Asteraceae, Galium sp., Gentiana sp., Plantago major/media and especially Thalictrum sp. allude to a diversification of the riparian/telmatic and tundra vegetation. Their high demand for light and comparable low habitus indicate that the landscape continued to be dominated by an open tundra-like vegetation. The characteristics of the assemblage zone are in line with those of the Hippophaë-Betula nana-PAZ as defined by Usinger (1985) for the area of investigation.

NAH-2b (cf. Meiendorf period, 15.335-15.270 m) 14,080 to 13,940 cal yr BP.

The lithological characteristics of the previous assemblage zone are met in NAH-2b as well. Very homogeneous clayey gyttja without visible stratification features stable or partly stagnating organic and $\mathrm{CaCO}_{3}$ sediment contents. Again, a dependence on the development of the green algae population (especially Pediastrum sp.) seems plausible, as it also shows stagnating or decreasing values.

Erosion indicators (HdV-704, pollen of thermophilous taxa and charcoal concentration values) display marginally higher values and Pinus sp. pollen values are increasing towards the end of the assemblage zone, the latter suggesting that an increased allochthonous input may be responsible. Two distinct minima in the overall pollen concentration are mainly caused by minima in Poaceae concentrations. This is in line with decreasing Poaceae percentage values mainly in favour of Helianthemum sp., Bidens sp. and AP values.

A comparison of the percentage values of Helianthemum sp. with other locations in northern central Europe reveals exceptionally high percentages (max. $>25 \%, \varnothing 14 \%$ ) for the investigated area: Stellmoor 3.4\% - Usinger unpubl.; Glüsing 5\% - Menke (1968); Kubitzbergmoor 5\% - Usinger and Wolf (1982); Slotseng 8\% - Mortensen et al. (2011); Hämelsee 5\% - Merkt and Müller (1999); Reinberg basin 1-3\% - De Klerk et al. (2001). A pollen-morphological distinction between a Helianthemum oelandicum-type and a $H$. nummularium-type (Beug 2004) was not possible and has yet been carried out at only few locations in Lateglacial context (Mortensen et al. 2011; 2014b). However, this is relevant for an interpretation, as associated species are either insect or wind pollinated (Lack 1982; Widén 2018).

Unfortunately, macrofossil evidence on Helianthemum sp. from Lateglacial contexts in northern central Europe is lacking so far.

In order to approach this problem, an indication is given by the record of Slotseng, in which both pollen types with clear dominance of the $H$. oelandicum-type were reported on (Mortensen et al. 2011). As with Hippophaë sp., the insect pollinated H. nummularium-type also implies local presence, 
assuming that both pollen types were included in a mixed ratio. This is concordant with the observations by Iversen (1944; 1947), Van der Hammen (1951) and Menke (1968).

Consequently, the high values suggest that Helianthemum sp. was present throughout the surrounding of the incision lake. Comprehensive and even exposed stands must be inferred. On the well-drained substrata of the vicinities different species of Helianthemum presumably formed a major part of the barren tundra or grassland and are indicative for calcareous and alkaline conditions in the area (Hoek 1997; Lang 1994; Rothmaler 2017; Widén 2018). This assumption is in line with the record of further heliophilous and partly thermophilous weed and steppe elements such as Galium sp., Plantago major/media, Selaginella selaginoides, Asteraceae and Chenopodiaceae.

The values of Helianthemum sp. appear significantly higher in a supra-regional comparison. A potential explanation would be the orientation of the Nahe palaeolake. The basin is aligned eastwest, bordered by shallow slopes. This implies that an elongated shore area is oriented to the south and thus locally optimal site conditions for rockrose (Helianthemum sp.) prevailed.

Presumably Juniperus sp. and Salix sp. as well as Betula nana and Hippophaë sp. continued to be present in the more sheltered locations and banks of the depression. A clump of Betula nana-type pollen potentially indicates local presence (De Klerk 2002; Janssen 1984) for the first time in the area. For Hippophaë sp., a second, albeit weakly pronounced maximum can be observed which can be compared to other sites in Schleswig-Holstein (Usinger 1985; 1998) as well as Denmark (Krüger \& Damrath 2019; Mortensen et al. 2011) and suggests, that sea buckthorn was prevalent among the shrub vegetation. The characteristics of the assemblage zone are mainly in line with those of the Hippophaë-Betula nana-PAZ as well as partly with the Helianthemum-Betula nana-PAZ as defined by Usinger (1985).

With regard to the Meiendorf period as a biostratigraphical unit, it should be noted that it cannot be clarified beyond doubt whether it has been recorded completely or only in part. Nevertheless, considering geographically close pollen profiles, the twofold maximum of Hippophaë sp. found within NAH-2 suggests a complete record of the Meiendorf period.

NAH-3 (cf. Dryas 1 period, $15.270-15.210$ m) 13,940 to 13,830 cal yr BP.

A minor change within the sediments is visible under consideration of the loss on ignition values within the assemblage zone. While the organic sediment content remains relatively stable, a strong decrease of the $\mathrm{CaCO}_{3}$ content is observed. Here, short-term water level fluctuations or a change in the duration of the vegetation period are plausible triggers for the synchronous decrease of Pediastrum sp. (Turner et al. 2014). Nevertheless, both are not to be seen here in direct dependence. 
The trigger for a decrease are probably the clearly lowered temperatures or/and increased dryness, that would correspond to the climate event GI-1d. Even if the given time ranges for the regional Dryas 1 period and the GI-1d do not overlap temporally, their offset is well within the given deviation of more than 150 years (Björck et al. 1998; Lowe et al. 2008; Mortensen et al. 2014b; Usinger 1985), or assumed uncertainty $( \pm 100)$ in the lower part of the age-depth model of the NAH record (Dreibrodt et al., in prep.).

A significant increase in pollen concentration is mainly due to an increase in Poaceae and Helianthemum concentrations within NAH-3. This can be attributed to the comprehensive distribution of the respective species in the area and the associated higher input of pollen. Unpretentious, low-growing species such as Artemisia sp., Rumex sp., Potentilla sp., Galium sp., Caryophyllaceae, Rosaceae and Chenopodiaceae are part of a now dryer steppe and grassland vegetation dominated by Poaceae and Helianthemum sp. Also the eponymous Dryas octopetala occurred. All these species successively occupied vacant areas abandoned by the retreating dwarf shrubs of Betula nana, Salix sp. and Juniperus sp., but in particular by Hippophaë sp.

Yet, a clump of Salix-type pollen still proves local presence. However, a distinction of pollen morphology is not possible on species level (Beug 2004). Although, local and regional finds of macrofossils suggest that Salix polaris, S.reticulata and probably most common S. herbaceae are amongst the present species (Bennike et al. 2004; Brandt 1954; Firbas 1949; Nathorst 1891; Schütrumpf 1937; Tralau 1963; Usinger 1985; Usinger and Wolf 1982).

De Klerk et al. (2008a) assumed that partly disappearing Hippophaë sp. could favour soil erosion. Nevertheless, an expected increase in various erosion indicators, here especially the Glomus-type (cf. G. fasciculatum; HdV-207), is not observed. On the contrary, these as well as dinoflagellate cysts, redeposited and corroded pollen grains gradually decrease. It can be deduced that the degree of soil erosion was either just insignificant, or the steppe and grassland vegetation already covered the majority of raw soils preventing them from being eroded.

Further, one should consider that a slight increase in Juniperus sp. values in the second half of the PAZ could be seen as a precursor to the subsequent spread of tree birches (Usinger and Wolf 1982). The same applies to the observations of Merkt et al. (1993), who interpret the repeated spread of Helianthemum sp. as a sign of an increase in temperature.

The characteristics of the assemblage zone are mainly in line with those of the Helianthemum-Betula nana-PAZ as defined by Usinger (1985) and indicate grass and herb dominated dry steppe in the surroundings of the lake. 
NAH-4a (cf. Allerød 1 period $15.210-15.110 \mathrm{~m}$ ) 13,830 to 13,710 cal yr BP.

A slightly pronounced alteration in the sediment is visible within the frame of the assemblage zone. This alteration - the increase of the organic sediment content - can be explained by increased allochthonous input. This is in line with the increasing pollen concentration within the sediment. Values rise from about 1500 to partly more than 4000 grains per $\mathrm{cm}^{3}$ sediment. Here, tripling Betula pubescens-type pollen concentrations are mainly responsible, but Betula nana-type pollen also contribute. The concentrations of grasses and herbs decrease only slightly. This is mainly due to a decrease in Helianthemum sp., while Poaceae maintain the concentration values. With regard to the AP/NAP-ratio it becomes clear that a rapid transformation of the vegetation occurred. In this respect the rapid increase in Betula pubescens-type pollen, here from around 25\% to more than $58 \%$, is typical for the onset of the Allerød period. The increase in pollen productivity was a response to rapidly increasing warmer climatic conditions of the $\mathrm{Gl}-1 \mathrm{c}_{3}$ (Björck et al. 1998; De Klerk 2002; Fredskild 1975; Hoek 1997; Hoek et al. 1999; Litt and Stebich 1999; Usinger 1985; 1998).

According to the biozonal characteristics at the type locality described by Hartz and Milthers (1901), the presence of tree sized birches is inevitable for an association with the Allerød period. In this respect it is important to note that a fruit scale of Betula pubescens has been identified (15.145 m), coinciding with the peak values of Betula pubescens-type pollen in NAH-4a. Further, the assumption of local presence is supported by a Betula pubescens-type pollen clump. The finds are in line with early macrofossil evidence of tree sizes birches in the area by Schütrumpf (1943).

The percentage values suggest that the spread of tree birches primarily occurred at the expense of Helianthemum sp., Artemisia sp., Hippophaë sp. and Juniperus sp. Taking the concentration values into consideration, however, it becomes clear that only Helianthemum sp. suffered a significant decline. For the high percentages of Betula pubescens-type pollen and the associated first spread of trees in the Lateglacial, it can therefore be stated that (i) such a high record of pollen can also be explained by the clearly superior pollen productivity compared to other species (Broström et al. 2008; Theuerkauf et al. 2012), which could also be explained by a few individuals and not necessarily by the development of a dense woodland, (ii) hybrid forms of Betula nana and Betula pubescens could equally have an unrecognised percentage share (Karlsdóttir et al. 2007), (iii) on the basis of the unchanged Poaceae concentrations a spread of birch trees certainly did not comprehensively cover the area, but took place selectively at favourable locations.

Light has always been a decisive factor in the competitive behaviour (Caldwell 1987; Horn 1971; Overbeck 1975). In this respect, migrating individuals of Betula pubescens would have been advantageous, but the first tree birches were far below their potential growth height presumable due to substrate conditions (Mortensen et al. 2014a). In addition, even at favourable locations, the 
populations were not particularly dense. This could explain why many grasses and herbs, as well as dwarf shrubs, were only partially prevented from spreading.

As reflected by the concentration values, Hippophaë sp. and Juniperus sp. spread at the beginning of the assemblage zone before being displaced again in some locations. However, Usinger (1975; 1981b; 1998; Usinger and Wolf 1982) was able to prove for several locations in Schleswig-Holstein that the concentration values of Hippophaë sp. in early Allerød (and in NAH-4a) are approximately as high as the maximum values during the Meiendorf period (NAH-2a2). Based on these observations and under consideration of the present record, it can be assumed that Hippophaë sp. may have spread almost to a similar extent within the early NAH-4a assemblage zone.

Moreover, considering numerous heliophilous species such as Potentilla sp., Artemisia sp., Bidens sp., Galium sp. (including a clump of pollen), Asteraceae, Caryophyllaceae, Chenopodiaceae and Rosaceae as well as the stable concentrations of Poaceae, it becomes clear that the vegetation cannot be characterized as forested (Bennett 2001; Chazdon et al. 2016). The appearance of vegetation in the landscape towards the middle of the assemblage zone can certainly be considered as groups of Betula pubescens individuals that are far from forming closed canopies. It seems plausible that stands of tree birches were mainly located in the sheltered riparian zone of e.g. incision lakes. Here, plausibly at e.g. the south-facing bank of the palaeolake. The population density was high enough to gradually displace shrubs (especially Hippophaë sp. and Juniperus sp.) through dominance in the competition for light.

The percentages of Pinus reached a first minimum within this assemblage zone. The former high percentages have so far been interpreted as an extra-local input into the basin, although evidence on regional Pinus sp. presence in Schleswig-Holstein is not absent (Schütrumpf 1958; Usinger 1998). If we assume that the percentage representation of long-distance pollen depends on local pollen production (Birks et al. 2005), it can be deduced that (i) the local vegetation forms a closed cover, thus (ii) the low percentages of Pinus can be explained, and (iii) the general extra-local input is potentially lowered.

Further, it is worth considering the concentrations of charcoal particles. As within the previous assemblage zones, the erosion indicators within this PAZ continue to decrease. This was previously associated with decreasing meltwater input into the lake basin. As meltwater transport has been interpreted as the main input path of charcoal, it is reasonable to assume that charcoal concentrations have equally declined so far. An explanation for the noticeable short-term increase at the transition from NAH3 to NAH-4a could be that fires in the catchment area of the lake are by now the source for the input. However, a response of the vegetation to a hypothetic fire event cannot be observed within the assemblage zone. Another explanation could be charcoal input by regional fires. 
As general remark, it can be said that there is a transition within this assemblage from an open grasses- and herb-dominated dry steppe to a very open, sparse and mosaic like woodland (Bennett 2001), reflecting an important step within the primary succession.

NAH-4b (cf. Allerød 2 period / Dryas 2 period, $15.110-15.050 \mathrm{~m}$ ) 13,710 to 13,610 cal yr BP. The previously observed stratification of the clayey gyttja is not recorded further within the boundaries of this assemblage zone. The strongly fluctuating values of $\mathrm{CaCO}_{3}$ can partly be explained by reflections of recorded mollusc fragments within the sediment. These in turn need to be considered in terms of potential lake level fluctuations. At the transition from the previous assemblage zone stronger alterations in the aquatic ecosystem can be observed. Pediastrum sp. and Botryococcus sp. display synchronous maxima and minima and also Spirogyra sp. (HdV-130) coincides with the changes at the transition. Later, the Filinia-longiseta-type reaches a maximum. In combination with the molluscs it needs to be assumed that water levels were presumably lowered at least seasonally during the assemblage zone (Van Geel 1989).

The overall concentration values likewise display a decrease at the transition towards NAH-4b. This is mainly due to a strong decrease in Betula pubescens-type and Betula nana-type pollen, which, however, is much less manifested in pollen percentages.

In the percentage composition a spread of grasses and herbs is reflected. It is noticeable that in addition to Artemisia sp., Galium sp., Rumex sp., Dryas octopetala and Poaceae also Brassicaceae are added to the previously referenced Dryas flora, whereas records of Selaginella selaginoides gradually decrease and disappear. Locally, in more humid areas - which may also become available due to lake level fluctuations - Thalictrum sp. and especially Cyperaceae spread rapidly.

In this assemblage zone, local stands of Betula pubescens on well drained predominantly sandy locations are displaced because of their low tolerance to drought of the corresponding $\mathrm{Gl}-1 \mathrm{c}_{2}$ (Mortensen et al. 2014a). Drought is further indicated as a reason for displacement by the fact that the abandoned areas are occupied partly by grasses and herbs, but predominantly by Juniperus sp. These have comparable temperature requirements as e.g. Betula pubescens (Bos 1998), but are much more tolerant to aridity (Miller and Wigand 1994; Willson et al. 2008). Previous macrofossil finds, however, suggest that a likely representative of Juniperus was J. communis (Fischer et al. 2013; Hartz and Milthers 1901; Mortensen et al. 2011). Thereby the species acted as further soil preparer and did not grow above shrub height (Iversen 1973). According to Usinger and Wolf (1982), it is plausible that Juniperus sp. was promoted by light and temperature until trees (Betula pubescens) in the following PAZ restricted growth again by shading. The characteristics of such a pre-woodlandphase or Vorwaldphase (Usinger 1998) can be seen in several diagrams in northern Germany: 
Stellmoor - Usinger unpubl.; Hämelsee - Merkt et al. (1993); Esinger Moor - Usinger (1981c); Kubitzbergmoor - Usinger (1981b); Glüsing - Menke (1968); Reinberg C - De Klerk (2008a). The palynological characteristics meet mainly those of the Juniperus-Betula pubescens-PAZ as defined by Usinger (1985). The landscape of the area is again characterised by a grass and herb dominated shrub steppe with a higher contribution of Juniperus sp., where tree sized birches were presumably only present at isolated locations.

NAH-4c1 (cf. Allerød 3a period / mid Allerød period, $15.050-14.760$ m) 13,610 to 13,120 cal yr BP. A very fine annual lamination can be observed in the sediment soon after the beginning of the assemblage zone (14.975). Presumably, this phase of fine stratification mainly is a result of decreased wind exposure due to increased tree and woodland cover of the surroundings (Lotter 1999). Furthermore, this corresponds to minor values and partly absence of erosion indicators (HdV-704, HdV-207, and rebedded pollen grains).

The strongly fluctuating values of $\mathrm{CaCO}_{3}$ are attributed to the presence of fragmented molluscs in the sediment. The generally decreasing tendency is contrary to the organic sediment content, which is in turn a mirror of increased external organic input due to woodland cover of the surroundings. The general concentration values tend to increase, with the shares of AP more than doubling. The initial strong fluctuations are due to Betula pubescens-type pollen and can partly be explained by changes in the sediment. A short-term drop in the organic sediment content and the initiation of fine lamination (14.975 $\mathrm{m}$ ) indicate an altered sedimentation rate, which explains the changes in pollen concentrations. The lower lying minimum (15.025 m) occurs within a sediment sequence of very homogenous material. On the one hand a non-detectable change in the sedimentation rate would be plausible, on the other hand, such alterations were attributed to a variable local tree birch spread as stated by Schütrumpf (1943).

Considering the pollen percentage diagram, the dominance of Betula pubescens-type pollen is evident. In this assemblage zone, the tree birches reach their maximum Lateglacial distribution of $\mathbf{7 7 7 \%}$. Therefore, it is not surprising that Betula pubescens is represented in the macrofossil record with fruit scales, benefitting from the temperature rise of the $\mathrm{Gl}-1 \mathrm{c}_{1}$. In this context, the decrease and partly the termination of the curves of heliophilous species (Artemisia sp., Bidens sp., Helianthemum sp., Rumex sp., Hippophaë sp.) points to the formation of a birch woodland. However, Betula pubescens, even in more comprehensive populations, is not capable of shading the ground effectively (Dörfler 2017).

The density of the woodland cover is mirrored in the well established presence of faunal remains of various forest animals (canis lupus, cervus elaphus, etc.) found in north-eastern Germany and 
southern Scandinavia during the Allerød period (Bratlund 1996; Wygal and Heidenreich 2014). Synchronously, the presence of large herbivores with antler spans of $2 \mathrm{~m}$ to more than $3.5 \mathrm{~m}$ (alces alces, megaloceros giganteus) indicates that the tree population (at least in major parts) may not have been dense (Bokelmann et al. 1983; Bratlund 1993; Riede et al. 2010; Terberger et al. 2004). This in turn would be consistent with the continuous values of Betula nana-type pollen and Poaceae. As far as those are concerned, the concentrations remain approximately constant, which plausibly reflects the still rather open character of the woodland. This is also indicated by the percentage and concentration increase of Betula nana, that is low tolerant to shade but still could thrive in such an open birch tree woodland (de Groot et al. 1997; Ellenberg et al. 2001).

Whether Pinus sp. was already a part of this open woodland or still remains an expression of allochthonous input cannot be clarified with certainty. However, it is noticeable that the concentration of Pinus pollen is increasing towards the end of NAH-4c1 and that Filipendula and Populus pollen, albeit with few examples, have also been detected. According to Usinger and Wolf (1982), the distribution of pine in Schleswig-Holstein is accompanied by the occurrence of Filipendula sp. and Populus (cf. tremula), which in turn is the only broad-leaved tree species during the Allerød period apart from Betula pubescens (De Klerk et al. 2008a; Theuerkauf and Joosten 2009). However, Schütrumpf (1943) reports on macrofossils of Pinus sylvestris during the mid Allerød period in the area. Further also Overbeck and Schneider (1938) mention several finds of Pinus sylvestris needles from Lower Saxony from the same time period. Even if the presence of pine in this assemblage zone cannot be proven locally, it is very likely and would be in accordance with the results of Firbas (1949) and Schütrumpf $(1937 ; 1958)$.

In this respect it cannot be ignored, that Usinger (1998) reported on much older charred wood fragments from the archaeological site Ahrenshöft that could without doubt be identified as Pinus sylvestris. According to biostratigraphy, its presence would fall within the maximum expansion of Hippophaë sp. and would hence imply a migration of Pinus sylvestris already during the Meiendorf period. However, as suggested by Usinger (1998) it is more likely that these charred fragments are the remains of potentially broken arrows or artefacts that are made of imported wood and not locally collected fuel (Caruso Fermé 2019). Further, also driftwood collected nearby at far reaching streams such as the Elbe river would be plausible (Mortensen et al. 2011).

Concerning NAH-4c1 special attention should be given to records of Ephedra dystachia-type and $E$. fragilis-type pollen. In northern central Europe there are several studies recording at least one of these types especially during the Allerød period. Nevertheless, some authors just record it without comment (Bos and Urz 2003; De Klerk et al. 2008a; Jahns 2000; Kolstrup 1982; Litt and Stebich 1999), some mention it and suggest long distance flight as source of origin (Fredskild 1975; Krog 1954), but 
some also infer presence without proof (Bos et al. 2018; Iversen 1973). It is possible that it was more widely spread across northern central Europe during colder periods of the Lateglacial as species of Ephedra are drought and cold tolerant. Nevertheless, there is still no macro botanical evidence on Lateglacial presence in northern central Europe (Lang 1994). Based on this lack of macrofossils, (ii) the very discontinuous Ephedra pollen record within the present study without clear pattern and (iii) with regard to species requirements of Ephedra sp. concerning light-demand and the fact that an open woodland spread locally, we clearly propose to attribute these pollen finds to the allochthonous input into the lake basin.

In the telmatic zone of the incision lake, Filipendula sp. (cf. ulmaria) sprouted on nutrient rich soils. In previous assemblage zones Thalictrum sp. and Bidens sp. had been able to spread here on the potentially periodically flooded banks.

The palynological characteristics of the assemblage zone meet mainly those of the Empetrum-Betula pubescens-PAZ as defined by Usinger (1985) with one constraint. This is the spread of Empetrum sp. that is not recorded in NAH and is attributed here to different local developments. Generally, a major transformation of the vegetation occurred as a result of the developing open woodland. In this woodland, Betula pubescens (on clayey soils) dominated but it is plausible that also Pinus sylvestris (on sandy grounds and river valleys) and Populus sp. contributed to the present tree species (Theuerkauf and Joosten 2009).

NAH-4c2 (cf. Allerød 3b period / Gerzensee-Oscillation/IACP, $14.760-14.710$ m) 13,120 to 13,030 cal yr BP.

Still, fine laminated sequences reflect constant and stable sedimentation conditions. Although, a short-termed change in the sediment is observable in the $\mathrm{CaCO}_{3}$ content. The values decrease from $14 \%$ to $4 \%$. An equal and synchronous drop is depicted in Pediastrum sp. values. This decrease in algae population as well as the drop in $\mathrm{CaCO}_{3}$ content might be caused by the colder climate of the corresponding Gerzensee-Oscillation (Björck et al. 1998; Lotter et al. 2000).

The palynological characteristics of the Gerzensee-Oscillation are defined by Andersen et al. (2000) for Denmark and resumed by De Klerk (2002), De Klerk et al. (2008a), Krüger and Damrath (2019), Mortensen et al. (2011; 2014b), and they are observable in NAH-4c2 as well. Pollen concentrations for Betula pubescens-type pollen are lowered whereas Pinus pollen concentrations increase - a development that is equally reflected in the percentage diagram. Here, slight increases in heliophilous species such as Artemisia sp., Plantago major/media and Filipendula sp. could indicate short-term and small scale openings of the already open woodland. Contrary to the more northerly 
areas, however, there is only a minor spread of grasses and herbs in total, but presumably a rather accelerated spread of Betula nana.

At the same time, a reduction in Betula pubescens-type pollen could be explained by reduced pollen production in consequence of reduced temperatures of the Gl-1b (Mortensen et al. 2011), which in turn could result in the higher concentrations and percentages of Pinus pollen. With regard to the presence of Pinus sp. it should be mentioned that a massive cluster of Pinus pollen has been recorded within this assemblage zone. Consequently, it is inferred that Pinus sp. (cf. sylvestris) was probably part of the local woodland.

Further, the local vegetation reflects a spread of species of wetter habitats. Cyperaceae, Equisetum sp. and Thalictrum sp. increase and the continuous record of Empetrum sp. could allude to more oceanic conditions and/or to a gradual leaching of carbonates (Bennike et al. 2004; Overbeck 1975). The coincidence of Sparganium sp., Sphagnum sp. and Cyperaceae indicate the formation of a local marsh zone and is an expression of the ongoing terrestrialisation.

In general, it is likely that only a slight change in vegetation can be expected during this assemblage zone. No significant further opening of the already open woodland can be inferred.

In conjunction with very different resolutions it becomes clear why relatively short oscillations are not reflected in the pollen profiles from Schleswig-Holstein so far. At low sample resolution, the Gerzensee-Oscillation (that is reflected in the NAH record for less than 100 years) might only be recorded in one or two samples and would hence potentially be neglected during zonation.

NAH 4c3 (cf. Allerød 3c period / late Allerød period, $14.710-14.570$ m) 13,030 to 12,840 cal yr BP. Alterations of the sedimentation rate within this assemblage zone are related to the influence of the Laacher See Tephra (LST), which is further used as an important isochronous time marker here (Brauer et al. 1999; Bronk Ramsey et al. 2015; Schmincke et al. 1999). The varve thickness is quadrupled temporarily, but the lamination continued (Dreibrodt et al., in prep.). This thickening of varves further explains the rapid but short-termed drop in organic sediment content. Here, the input of silicates in particular favoured the preservation of diatoms for about 20 years (Dreibrodt et al., in prep.). Congruently, a time range of 20-25 years is given by Merkt and Müller (1999) for the Hämelsee sequence and by Litt and Stebich (1999) for the Meerfelder Maar sequence until the sedimentological conditions returned to their state prior to the Laacher See eruption (LSE). The LSE is one of the most powerful eruptions of the late Quaternary (Schmincke et al. 1999). Therefore it is not surprising that cryptotephra was found in the sediments of the Nahe palaeolake (Krüger \& van den Bogaard, in prep.), even if the position was previously considered to be located outside the known ash fallout zone (Riede et al. 2011; van den Bogaard and Schmincke 1984). Hence, 
the question arises to what extent the LSE had a detectable effect on the local and regional environment.

Sediment analyses of the respective NAH record section revealed that the introduction of different material from the LSE conditioned a slight acidification of the lake system. Generally, an aquatic ecosystem reacts directly to alterations. In this respect the strong and immediate rise in Pediastrum sp. and Botryococcus sp. values subsequent to the LSE can be linked to altered competition conditions favouring different green algae species (Dreibrodt et al., in prep.; Weckström et al. 2010). The concentration values reveal that various telmatic and upland species report an increase around the LST. However, in contrast to green algae values, they do not rise synchronously and occur before (Pinus sp., Betula pubescens-type, Artemisia sp., Poaceae, Cyperaceae), at (Salix sp., Filipendula sp., Rumex acetosa-type) and after the cryptotephra layer (Juniperus sp., Menyanthes sp., Chenopodiaceae). Following De Klerk et al. (2008b) it is plausible that these increases in concentration are linked to temperature rises succeeding the Gerzensee-Oscillation rather than being connected to an eutrophication of the environment by nutrient input through the LSE. Equal degrees of delay in pollen concentration increase can be explained by amplified varve thickness. General small scale changes in the palynological spectrum could also be related to increased allochthonous input by stronger erosional processes through storms and extreme weather events following the LSE (De Klerk et al. 2008b; Schmincke et al. 1999). These led to short term discontinuations of the annual stratification of the NAH sediment record that coincide with synchronous drops in various concentration curves (Dreibrodt et al., in prep.).

Coinciding maximum values of Filipendula sp., Salix sp. and Cyperaceae are apparent. A spread can be related to an increase in the water level that in turn was controlled by heavy rainfall following the LSE (Dreibrodt et al., in prep.; Theuerkauf 2003).

In this context the decline of the bank vegetation can also be seen. Here, decreasing or fluctuating values of Sphagnum sp., Menyanthes sp., Sparganium sp. and Equisetum sp. can be observed, relating to unstable water tables.

Consequently, considering the environmental impact of the LSE to the surrounding of the Nahe palaeolake we might assume that a change within the aquatic ecosystem occurred abruptly, whereas the upland vegetation does not seem to be effected.

Up to the following assemblage zone, the concentration and percentage values of Betula nana-type pollen show a classical sawtooth pattern without an obvious tendency. Differences in the sample preparation are not given and even unlikely, because only Betula nana-type pollen are affected. A spread of Betula nana after a drop of the water level and a drought is not to be assumed, because Betula nana is especially sensitive to dryness (Ellenberg et al. 2001). Also the parallelization with 
corresponding high-resolution regional diagrams (Stellmoor - Usinger unpubl.) shows no further spread of dwarf birches.

Fluctuations (although independent of B. nana) can also be observed in B. pubescens. Both could potentially be related to different pollen productivity in different flowering years (Sugita et al. 2010).

NAH-4c4 (cf. Allerød 3d period / late Allerød period, $14.570-14.370$ m) 12,840 to 12,540 cal yr BP. The palynological assemblage and the geochemistry of $\mathrm{NAH}-4 \mathrm{c} 4$ are controlled by two important factors. The first is a profound fire event that occurred around $14.525 \mathrm{~m} / \sim 12,790$ cal yr BP to which a reaction of the vegetation is observable. The second, however, is a fast but gradual alteration around $14.448 \mathrm{~m} / \sim 12,700$ cal yr BP from annually laminated to very homogenous sediments. These factors and the resulting effects need to be considered separately, although, with regard to biostratigraphy, they belong to the same unit - describing the transition from a dense woodland to a shrub tundra. This overarching transition is clearly visible in (i) the AP/NAP ratio, which changes from 90/10 to 70/30, here mainly to the decrease of Betula pubescens-type pollen, (ii) in an overall decrease in pollen concentration from about 6000 to about 3500 pollen per $\mathrm{cm}^{3}$ sediment and (iii) the corresponding decreasing tendencies in organic sediment content and $\mathrm{CaCO}_{3}$ content.

With regard to the peak in charcoal particle concentration and in coincidence with increased occurrences of larger particles (charcoal size classes $>50 \mu \mathrm{m}$ ), a fire of unknown size is inferred. Rearrangement or secondary deposition of the charcoal particles can be excluded, as for the first time these do not display similar trends as erosional indicators. Here, single high values of charcoal coincide with absence of HdV-704 and HdV-207. This is further supported by the fact that continued stable conditions in and around the basin are indicated by the persisting annual lamination of the sediment. Finally, a reaction of the vegetation (natural succession) is observable succeeding the charcoal peak.

A drop in the organic sediment content can be observed as a direct result of the fire event and its impact on the environment. It is possible that the produced black carbon and ash was introduced into the lake system and caused a slight eutrophication (Pediastrum sp. and Botryococcus sp.) (Odhiambo and Routh 2016).

A strong decrease of Betula pubescens-type pollen visible in concentration and percentage values as well as less pronounced decreases of Juniperus sp. and Betula nana-type pollen are the direct consequence of the fire. In contrast, Pinus sp. does not appear to have been adversely affected as an increase is indicated directly subsequent to the fire.

This opens up two possibilities for an interpretation. On the one hand it is possible that the immediate higher input of Pinus sp. pollen can be interpreted as an increased allochthonous 
component, in direct consequence of reduced woodland cover. However, this seems unlikely, as the sediments, which are continuously annually laminated, display practically no variation in layer thickness.

On the other hand, it could be assumed that the fire was not a crown fire but a surface fire. This would explain why shrubs such as Juniperus sp. and Betula nana are particularly affected. Betula pubescens could also be affected, as leaves and bark can easily burn in periods of extreme drought. Pinus sp., in turn, is at least partially protected against ground fire by the growth of a bark (Fernandes et al. 2008; Pausas 2015).

The second explanation seems plausible, as here the woodland cover would only partially decrease and continue to contribute to a certain protection against wind, which would firstly favour the formation of varves in the lake and would secondly explain the rapidly increasing Pinus concentration and percentage values.

Clearly grasses and herbs would have been burned and effected as well, but as one sample covers several years (here about 5) a decline would only be visible on an annual resolution level. Therefore, the record shows that grasses and herbs directly benefitted during the following growing seasons from the brightening up of the ground and the partly reduced shading. This explains the synchronous spread of Artemisia sp., Filipendula sp., Galium sp., Salix sp. (cf. herbaceae), Menyanthes sp., Chenopodiaceae, Rosaceae and Poaceae. Especially the continuous record of Helianthemum sp. indicates the reduced degree of shading. Further, this is in line with evidence on the heliophilous and entomophilous Epilobium sp. (cf. angustifolium) that initially colonized burned areas (Keeley and Keeley 1987; Tinner et al. 2008).

Regarding the cause of the fire, a phenomenon seems plausible that is reflected at the transition from Allerød period to Dryas 3 period at multiple sites and records in northern central Europe. Due to extreme drought, temporally undefined wildfires occurred here, which subsequently led to the formation of the Usselo and Finow horizons at terrestrial sites (Crombé 2016; Hoek 1997; Kaiser 2003; Kaiser et al. 2009; Tolksdorf et al. 2014; Van der Hammen and Van Geel 2008). In limnic archives of Jutland and Schleswig-Holstein at the transition from the Allerød period to the Dryas 3 period often hiatuses can be observed (Krüger \& Damrath 2019; Iversen 1942; Usinger 1981a; Usinger and Wolf 1982). Here, these hiatuses are mainly the result of the mentioned droughts that in turn are responsible for lake level fluctuations and extensive redeposition processes (Kasse 1997; Usinger 1981a). As the presented sediment sequence derives from the center of the former incision lake these fluctuations only had a minor effect, explaining a continuous record and the reflection of a fire event. 
After the fire the new spread of the tree birches began until about 20-23 years later the conditions prior to the fire event existed again. However, once these conditions are reached, a gradual opening of the woodland occurred, which is indicated by strong increases of Artemisia sp. and Filipendula sp. towards the upper boundary of the assemblage zone.

The gradual opening is particularly reflected in the concentration values of Betula pubescens-type pollen that now fall to levels equal to stadial periods. Pinus sp. declines to an equal extend. The inferred loss of woodland cover resulted in pronounced exposure to wind and further erosional processes and explains the termination of yearly laminae in the sediment (Lotter 1999; Usinger 1981a).

The altered sedimentation conditions caused strong fluctuations in organic sediment content and $\mathrm{CaCO}_{3}$ content. The latter decreases extremely towards the upper boundary and thus compares Europe-wide records of the beginning Dryas 3 period (Hoek et al. 1999; Mortensen et al. 2011; Van Asch et al. 2012).

Immediately coinciding with the sediment change, erosion indicators reappear (HdV-704, HdV-207, and rebedded pollen grains). The concentration of charcoal particles rises equally, without any visible reaction of the vegetation. Therefore, these now suggests rearrangement or secondary deposition rather than further fires, although this cannot be excluded with absolute certainty.

The gradual transformation of a dense woodland into a shrub tundra is manifested in the increase of pollen of heliophilous grasses and herbs (Artemisia sp., Rumex acetosa-type, Ranunculus acris-type, Potentilla sp., Caryophyllaceae, Asteraceae, Chenopodiaceae, Poaceae) and Betula nana-type pollen as well as the overall decrease in AP. The record of the heliophilous but also thermophilous Filipendula sp. revealed decreasing concentration and percentage values. This is explained by the decreasing temperatures, which is the limiting factor here.

Rising water levels or at least changed precipitation conditions ensure that Equisetum sp. and especially Cyperaceae spread among the local and riparian vegetation. In conjunction with an accelerated spread of Menyanthes sp. and the presence of Sphagnum sp. this is likely to reflect oligotrophication (Menke 1968).

The quantitative and temporal contribution of Betula (cf. pubescens), Pinus (cf. sylvestris) and Populus (cf. tremula) deadwood in the landscape is difficult to estimate. It is likely that up to a certain point dead trees also contributed to the landscape at the end of the Allerød period. But apart from spores of Gaeomannomycetes hyphopodia (HdV-126) and clusters of globose fungal cells (HdV-200) both potential indicators of local stands of Carex sp. that fit well with the recorded Cyperaceae pollen 
(Kuhry 1997; Van Geel 1989) - there are no expectable indicators for wood decomposition in the record.

It can of course be argued that this last section of the assemblage zone (from 14,448 m / 12,700 cal yr BP onwards) can already be ascribed to the Dryas 3 period. As the boundaries were set according to biostratigraphy, they do not necessarily coincide with lithological boundaries (Hedberg 1976; Leroy et al. 2000). Therefore, the biostratigraphic unit Dryas 3 in this profile comprises exclusively that section which reflects fully developed stadial conditions. Assemblage zone NAH-4c4 apparently reflects the transformation of the vegetation from a dense woodland to a shrub tundra and is hence categorized as belonging to the Allerød period. Therewith, the (biostratigraphic) Allerød period extends far into the (climatically defined) GS-1, highlighting once again that biostratigraphic terms and climatic phases are not to be used as synonyms.

NAH-5a (cf. Dryas 3a period, $14.370-14.240$ m) 12,540 to 12,030 cal yr BP.

The assemblage zone comprises very homogeneous clayey gyttja without recognizable stratification. It includes a significant portion of coarse-grained material that suggests rising degrees of different erosional processes - especially aeolian activity (Bakke et al. 2009; Brauer et al. 2008). In addition, the sediment sequence of NAH-5a encompasses the Vedde Ash (14.260 m/ 12,110 cal yr BP), which is deposited just before the upper zone boundary. An environmental impact cannot be estimated as potential (if any) influences are masked or blurred by the degree of redeposition. This is apparent through the common tail-off pattern of the cryptotephra shards into the following assemblage zone as well as through bioturbation of fewer shards rearranged into slightly deeper levels (Krüger \& van den Bogaard, in prep.).

Lime precipitation had completely ceased by the end of the previous assemblage zone. According to Hoek et al. (1999) this is controlled by the deep seasonal frost, a major drop in July temperatures as well as permafrost formation in the area (Theuerkauf and Joosten 2012). The organic content of the sediment decreases to levels comparable to the Meiendorf or Dryas 1 period. This can be explained by the significant loss in biomass around the incision lake and the strong reduction of aquatic productivity. However, the depth $14.310 \mathrm{~m} / \sim 12,310$ cal yr BP marks a turning point.

By that depth organic proportions of the sediment continuously rise. The only detectable change at this stage is an extreme increase in Pediastrum sp. concentrations and percentages. This was preceded by a spread of Botryococcus sp. Nevertheless, it is rather unlikely that these green algae are the reason for an upheaval in the organic sediment content. It is far more plausible that the previous reduced organic sediment content can to a certain point be explained by erosion of former bank sediments and their secondary deposition due to a lowered lake level. This in turn leads to the 
conclusion that the interpretation of the palynological record can only be done with caution, as it is also masked by rearrangement.

Rearrangement and redeposition of older sediments are further emphasized by the anewed closed curves of HdV-205 and HdV-704. At the same time the record of Desmidiaceae (HdV-332) reflects stadial conditions and is indicative for the Dryas 3 period throughout northern central Europe (Van Geel 1989).

Tripled concentrations of charcoal particles can likewise be associated to some extent with increased erosion. A wildfire in the immediate vicinity of the basin is excluded, as unlike within NAH-4c4, no recognizable reaction of the vegetation is discernible. This is further referred to in 4.5 considering charcoal particles of the palynological record and in detail by Krüger (in prep.).

The general pollen concentration rate in the sediment displays only slightly lower values compared to the terminating Allerød period. However, the composition underwent a marked change. The proportion of AP drops to about $30 \%$. Here, continuously long-distance flight is the undoubted explanation for unaltered $10 \%$ of Pinus pollen concentration throughout NAH-5a and $5 \mathrm{~b}$. The further decreasing values of Betula pubescens-type pollen can likewise rather be explained to a certain extent by long-distance transport (Hjelmroos 1991; 1992; Wallin et al. 1991). However, Betula pubescens macrofossils are present in the NAH record. Certainly, these too may have been subject to rearrangement and could well originate from the previous Allerød period. Nevertheless, the high number of detected nutlets and fruit scales of Betula pubescens across the region highlight the presence of trees during the Dryas-3 at least in southern parts of Schleswig-Holstein (Firbas 1949; Schütrumpf 1943; Usinger 1981b; 2004).

Betula nana-type pollen (supplemented by finds of macrofossils) reached their Lateglacial maximum values by the beginning of NAH-5a and likewise Poaceae values increase strongly, indicating a significant spread. This coincides with the incipient and continuous record of diverse heliophilous species such as Artemisia sp., Selaginella selaginoides, Dryas octopetala, Ranunculus acris-type, Caryophyllaceae, Asteraceae, Chenopodiaceae (also recorded as macrofossil) and Helianthemumtype pollen, reflecting a regime shift of the vegetation towards an open heathland/steppe like vegetation. Although, significantly lower values indicate less pronounced distributions than, for example, during the Meiendorf and Dryas 1 period. As already suggested by Iversen (1954) Empetrum sp. (cf nigrum) here supersedes Helianthemum sp., which can be interpreted as a clear sign for the leaching of carbonates from the soil (Bennike et al. 2004; Overbeck 1975). This is in line with the continuous presence of the more acidophilous Rumex acetosa-type, Calluna sp. and Vaccinium-type pollen. 
We might assume that low tree birches grew at favourable locations, such as the banks of the Nahe palaeolake, and partly formed riparian woodlands, with the majority of the vegetation being dominated by a grass and shrub-heath tundra. Here Betula nana and Empetrum sp. (cf. nigrum) predominated the mosaic-like vegetation dispersal in the landscape that Usinger (2004) understandably refers to as park-tundra.

It has been assumed on several occasions to divide the Dryas 3 period into two phases. The first phase would here, on the one hand, be characterised by persisting dryness with very cold winters due to sea ice formation in the North Atlantic - but still rather warm summers. In particular the latter could here be inferred from Filipendula sp. and Urtica sp. pollen, which are exclusively recorded during NAH-5a.

The second phase, however, would then be controlled by more oceanic conditions, i.e. rising humidity and on average colder summers, which is consistent with the palynological assemblage of the following NAH-5b (Bakke et al. 2009; Broecker 2006; Denton et al. 2005; Isarin and Bohncke 1999; Leroy et al. 2000; Merkt and Müller 1999; Overbeck 1975; Theuerkauf and Joosten 2012; Usinger 1981b).

NAH-5b (cf. Dryas 3a period / late Younger Dryas period, $14.240-14.140$ m) 12,030 to 11,560 cal yr BP.

A homogeneous clayey gyttja including coarse-grained material further characterizes also the sediment sequence of NAH-5b. Whilst the $\mathrm{CaCO}_{3}$ content remains unaltered low, the organic content continues to increase. Following De Klerk et al. (2008a) the higher organic content in comparison to the Dryas 1 period is controlled by less allochthonous input due to a denser vegetation cover of the park-tundra. However, redeposition, potentially of mobilized material from the shore, is unequivocally indicated by HdV-205, HdV-704 and Cenococcum geophilum sclerotia. This is in line with fragments of wood of Populus tremula. It was found at $14.220 \mathrm{~m} / \sim 11,940 \mathrm{cal}$ yr BP and has been dated twice (Dreibrodt et al., in prep.). Both radiocarbon dates give equal results and fall well within the Allerød period, emphasizing persisting rearrangement of potentially Aller $\varnothing \mathrm{d}$ sediments from shallower areas or the shore line.

The remarkably high concentration values of charcoal particles can equally be explained to a certain extent by redeposition. Thus, a wildfire near the incision lake cannot be assumed, as there is no reaction of the vegetation inferable from the record. It is remarkable that these high values coincide with the reconstruction of more humid conditions (see below). Therefore, and because of the archaeological record in the vicinity (Wild 2017), human-environment-interaction must be 
considered as an additional component of the total charcoal concentration. This is further referred to in 4.5 considering charcoal particles of the palynological record and in detail by Krüger (in prep.). Already in the previous assemblage zone, a strong increase in Pediastrum sp. values was recorded, which rise up to the clear Lateglacial maximum in NAH-5b. As Pediastrum sp. and Botryococcus sp. both include various taxa that differ in ecological requirements (Jankovská and Komárek 2000; Komárek and Marvan 1992), it is not clear what caused this rapid spread. However, this can hypothetically be linked to (i) further lake level alterations or, more plausible, to (ii) nutrient input via aeolian activity (Brauer et al. 2008).

The general pollen concentration in the sediment decreases marginally. However, increases of Pinus sp. and Empetrum sp. - which characterize this assemblage zone in the percentage diagram - are clearly visible, due to the fact that concentrations of other pollen types are decreasing considerably. These include Betula pubescens-type, B. nana-type and Artemisia sp. pollen. Consequently, a minor decline of these species is more likely than a significant expansion of Pinus sp.

There is again a distinct sawtooth pattern observable in the concentration values. Within NAH-5b this affects several pollen types simultaneously (Poaceae, Cyperaceae, Artemisia sp., Betula pubescenstype, $B$. nana-type) and could thus be associated with differences in sample preparation. Samples with lower concentrations were taken from a more recent series of subsampling and were treated temporally longer with acetolysis (Fægri and Iversen 1989). Additionally, increasing humidity and colder summers could be another factor that adversely affected the general pollen production of different species during this assemblage zone resulting in an overall concentration decline (Overbeck 1975; Usinger and Wolf 1982).

The assumption concerning colder summers would be in line with the termination of evidence of Urtica sp. and a further decline of Filipendula sp. In contrast, the absence of Pinus sp. in the area is rather linked to permafrost formation (north of $53^{\circ} \mathrm{N}$ ) during the Dryas 3 than to lower summer temperatures (Theuerkauf and Joosten 2012).

During NAH-5b characteristic steppe elements (Artemisia sp., Poaceae, Chenopodiaceae) and especially elements of the shrub tundra (Betula nana, Empetrum sp., Juniperus sp.) were continuously dominant among the vegetation. Betula pubescens probably remained present in the most sheltered places. Indicators of stadial conditions (Dryas octopetala, Selaginella selaginoides) and numerous other heliophilous species (Helianthemum sp., Ranunculus acris-type, Rosaceae, Asteraceae, Caryophyllaceae) were common.

Within the mosaic-like vegetation in the landscape there was a shift in importance of Betula nana and Empetrum sp. (cf. nigrum). The latter is favoured in certain regions by the increasing oceanity and in others by the increased formation of dunes as a result of aeolian activity. Both is controlled by 
relatively warm and moist winds. The resulting accelerated expansion of Empetrum sp. (cf. nigrum) is shown in maximum distributions in a wide range along the coastal areas between the Netherlands, Northern Germany and Denmark (Bakke et al. 2009; Behre 1966; De Klerk 2008a; Hoek 1997; Hoek et al. 1999; Iversen 1954; Litt and Stebich 1999; Merkt and Müller 1999; Mortensen et al. 2014b; Müller and Kleinmann 1998; Odgaard 1994; Usinger and Wolf 1982).

The appearance of vegetation in the landscape remained a mosaic of predominantly tundra and steppe elements, but possibly with groups of tree birches in the most sheltered and protected places, on southern slopes of low moraine ranges and the riparian zones of various wetlands areas and streams (Usinger 2004).

NAH-6a (cf. Preboreal a/ early Preboreal/ Friesland Oscillation, $14.140-14.030$ m) 11,560 to 11,390 cal yr BP.

NAH-6a covers a sediment sequence of very homogeneous gyttja with increasing organic content. Coarse-grained material is no longer found. This coincides with the termination of the curves of various erosion indicators (HdV-205, HdV-704, corroded and rebedded pollen grains), which in sum suggests a reduction of different erosional processes in and around the lake. Only the charcoal particle concentrations display slower declining tendencies and temporarily remain at higher levels. This is again further referred to below and in detail by Krüger (in prep.).

The resumption of $\mathrm{CaCO}_{3}$ precipitation is clearly controlled by the rapidly increasing temperatures that are generally responsible for the massive alterations in vegetation composition in this assemblage zone (Björck et al. 1998; Johnson et al. 1992).

The general pollen concentration in the sediment reveals partly a more than tenfold increase of the values. While Pinus sp. pollen concentrations marginally rise, its actual presence cannot be clarified. Here, Betula pubescens-type pollen constitute the dominant share, but also Betula nana-type pollen, Salix sp., Filipendula sp. and Poaceae proportions increase.

Concerning Betula pubescens-type pollen in particular, different factors interact here: The presence of tree birches during the preceding Dryas 3 period implies that a dispersal of birch trees can occur immediately succeeding the temperature rise, without possible time-lag. Furthermore, the temperature stimulated the pollen production, which in sum explains the substantial increase of the concentration values. Therefore, in southern Schleswig-Holstein, there is no pronounced Juniperus phase heralding the spread of woodland, as is known from Danish records (Krüger \& Damrath 2019; Mortensen et al. 2011). It is observable in the concentration values, that there is a rise in Juniperus $\mathrm{sp}$. values in the early Preboreal period that might even be stronger pronounced than during the early Allerød period. However, a potential widespread distribution of Juniperus sp. is potentially 
masked by the strong pollen production of the tree birches. Also, and contrasting the early Allerød period, this rise coincides with the mass expansion of tree birches (B. pubescens and pendula). Macrofossils have so far proven that Betula pendula was strongly expanding in Schleswig-Holstein by the beginning of the Preboreal period (Usinger and Wolf 1982). Their distribution is bound to higher summer temperatures, a longer duration of the vegetation period and the melting of permafrost (Theuerkauf and Joosten 2012) - all given in the course of the Preboreal period.

Consequently a further birch species is presumably present in the record that produce pollen of a size that lays statistically between B. pubescens and B. nana (Beug 2004; Usinger and Wolf 1982). This means that an application of the defined threshold of $21.5 \mu \mathrm{m}$ can no longer be justified. Pollen of $B$. pendula and potential other hybrid forms explain the fluctuations of $B$. nana-type pollen values. These fluctuations of concentrations and percentages in the early Preboreal period are probably less related to the spread of $B$. nana than to the spread of B. pendula. Certainly, B. nana was still present at some sites, but the high pollen concentration of $B$. pubescens-type pollen suggests that tree birches (both, B. pubescens and B. pendula) formed closed stands. Usinger and Wolf (1982) suggested that B. pendula spreads on drier soils. This could explain the low values of Pinus sp. as its spread could presumably be partially prevented.

Large-scale shading of smaller growing plants is illustrated by strong declines or terminations of the values of heliophilous species (Helianthemum sp., Artemisia sp., Rumex sp., Ranunculus acris-type, Bidens-type, Empetrum sp., Chenopodiaceae, Caryophyllaceae, Asteraceae). However, also the increased pollen productivity of Betula species - potentially taking advantage of the warmer temperatures - could lead to an overall declining effect in other pollen types. However, conversely the values of the Poaceae increased. Here Phragmites sp. is suspected to contribute to a certain extent, masking the actual decline of upland grasses (Averdieck 1957; De Klerk 2002; Overbeck 1975; Usinger 2004). Phragmites sp. possibly established as part of the bank vegetation, to which also Equisetum sp. and Cyperaceae belonged. The spread of bank vegetation with the beginning of the assemblage zone is in turn closely related to the rise in temperature. Filipendula sp. and especially Typha latifolia imply that the annual average temperature reached at least $13^{\circ} \mathrm{C}$ (Bos 1998).

The declining Pediastrum sp. values can presumably be explained by less erosional material that is introduced into the basin. Likewise, it could be connected with a spread of Myriophyllum sp. (cf. spicatum). Accordingly, there must have existed sufficient shallow water areas near the banks where it could thrive (Rothmaler 2017). Whether the expansion of Myriophyllum sp. is controlled by an upheaval of the lake level - as suggested by Usinger (1981a) for lakes throughout Schleswig-Holstein in the early Preboreal period - cannot be deduced. However, apart from the presence of the 
Myriophyllum spicatum-type and the termination of the curve of Spirogyra (HdV-131) there are no further signs of altered lake levels here.

At the beginning of the Holocene, a primary succession started, that has been named FrieslandSchwankung / Friesland-Oscillation by Behre (1966) and was as further described by Iversen (1973), Overbeck (1975), Odgaard (1994), De Klerk (2002), Hoek (2001), Usinger (2004) or Nelle and Dörfler (2008) for northern central Europe. Concerning the surroundings of the Nahe palaeolake, the parktundra was replaced within a relatively short timeframe by a birch forest that extended over large parts of the landscape. The share of dwarf birches cannot be determined from pollen statistics by the beginning of the Holocene. Here, for the Nahe palaeolake, current studies on lipid biomarkers may provide further information (Weber, in prep.).

NAH 6b (cf. Preboreal b/ Preboreal Oscillation/ Rammelbeek phase, 14.030 - 13.955 m) 11,390 to 11,250 cal yr BP.

$\mathrm{NAH}-6 \mathrm{~b}$ spans a sediment sequence of homogeneous gyttja with rarely altering (increasing) organic content and $\mathrm{CaCO}_{3}$ content. However, significant changes in pollen concentrations are apparent. The total pollen concentration declines by approximately one half, whereby this is particularly at the expense of Betula pubescens-type pollen.

In case that the landscape becomes more open, one would expect the heliophilous Betula nana to expand at least temporarily. The concentration values of Betula nana-type pollen, however, are likewise declining. This can be explained by the assumption that $B$. pendula actually had large proportions of both birch pollen types since the beginning of the preceding assemblage zone. Their previous distribution was particularly limited by the low temperatures (Theuerkauf and Joosten 2012). Decreasing annual mean temperatures are now again restrictive (Kromer and Becker 1993; Lotter et al. 1992). However, it is most unlikely that an actual opening took place. It can rather be assumed that lower temperatures predominantly led to lower pollen production (Theuerkauf et al. 2014).

The absence of erosion indicators - here especially soil erosion (HdV-205 and Cenococcum geophilum) - would be an argument against an opening of the landscape. Further, also the absence of coarse grained material in the sediment suggests a closed vegetation cover - with regard to the pollen composition predominantly of forest character. Nevertheless, rising trends in Poaceae pollen concentrations and percentages are evident. In the previous assemblage zone it has already been assumed that Phragmites sp. contributed to this to a certain extent (Usinger 2004). To assume an opening due to a general Poaceae increase is therefore not justified. 
In case that this could be excluded, a slight spread of the Poaceae could, however, equally be related to the shadowing of Empetrum sp. and Calluna sp. due to the forest cover. Grasses, herbs and ferns (cf. Polypodium sp.) would thrive in the shady undergrowth of the denser birch forest (Overbeck 1975). Nevertheless, apart from minor increases in Rumex sp., Thalictrum sp. and Salix sp. (cf. herbaceae) there are no further observable alterations in pollen values of low growing plants. Whether Pinus sp. gradually became part of the forest remains uncertain. In contrast, macrofossils of Populus tremula are a clear indication for the presence of this tree during the early Preboreal period (Schütrumpf 1937; Usinger 2004), despite the fact that Populus sp. is generally represented with very low values: present study $<1 \%$; Slotseng $<1 \%$ - Mortensen et al. (2011); Hämelsee 1\% - Merkt and Müller (1999); Westerhauderfehn 1\% - Behre (1966); Stellmoor 8\% Usinger unpubl.; Kubitzbergmoor 1-2\% - Usinger (1981b); Scharnhagener Moor 1-2\% - Usinger (1981b).

Changes of the vegetation within this assemblage zone are considered to be controlled by a shorttermed climatic setback and hence are in line with multiple records across northern central Europe (Björck et al. 1997; Iversen 1973; Lotter et al. 2000; Usinger 2004; Van Geel et al. 1981). Here, this assumption is supported by the reaction of thermophilous species. While Filipendula sp. is significantly decreasing in concentration and percentage values, the curves of Typha latifolia and Myriophyllum spicatum terminate. As a result, the average July temperature has probably undershot the $13^{\circ} \mathrm{C}$ limit (Bos 1998). This lead to a shift in competition among different species potentially favouring Equisetum sp. that hence occupied habitats on the banks of the lake.

In this assemblage zone, an opening of the forest, if actually occurring, is only marginally. The observed decline of certain species depends in some cases on their low tolerance of lower average July temperatures. This leads on the one hand to a decline in the population (Typha latifolia, Myriophyllum spicatum, Filipendula sp.) and on the other hand to a reduction in pollen productivity (cf. Betula pendula).

NAH-6c (Preboreal c/ late Preboreal period, $13.955-13.695 \mathrm{~m}$ ) 11,250 to 10,750 cal yr BP. The abundant production of organic matter by the surrounding forest causes a further increase in the organic content of the gyttja. A change in sediment towards a reduced $\mathrm{CaCO}_{3}$ content within this assemblage zone could at least partly be linked to the growth of Nymphaea sp. The expansive leaves of the water lily probably shade algae (Botryococcus sp., Pediastrum sp., HdV-603), which further decreased lime precipitation and explains the fluctuation of $\mathrm{CaCO}_{3}$ content in the sediment (Hoek et al. 1999). 
The beginning of NAH-6c coincides with a peak in charcoal particle concentrations. Nevertheless, only minor changes can be observed in the concentration values of several species (Artemisia sp. Poaceae, Betula nana-type, Betula pubescens-type, Pinus sp., Equisetum sp.), but they do not reveal any discernible correlation or succession as in NAH-4c4 (late Allerød period). A potential wildfire remains uncertain.

The assemblage zone is characterized by a general renewed increase of pollen concentrations in the sediment. In particular, AP have a strong proportion, with Betula pubescens-type pollen rising immediately, while Pinus sp. pollen values increase steadily and gradually. Strongly fluctuating but generally increasing proportions of Betula nana-type pollen are again bound to the influence of $B$. pendula pollen. A dense forest appears plausible and explains the lack of heliophilious herbs and shrubs. The undergrowth of the trees is composed of different species of the Poaceae family, as well as an increasing amount of ferns (Dryopteris sp., Polypodium indet.).

An increase in Poaceae is connected once again with an expansion of Phragmites sp. This is plausible in consideration of the development of a dense and tall growing bank vegetation of Typha latifolia, to which Sparganium sp. subsequently follows. Here, they replace Filipendula sp. and Equisetum sp. in particular.

A dense forest can be assumed for NAH-6c, in which Pinus sp. became progressively important. The proportion of Betula nana cannot be estimated, although it is plausible that it was gradually shadowed and could not thrive for long in the undergrowth of the Early Holocene forest.

Usinger (2004) suspected a second Preboreal oscillation (PBO2) that would fall within NAH-6c. This hypothetic oscillation, however, cannot be detected here. The visible changes in pollen composition are well within the expected natural range and do not reveal alterations where climatic causes must be considered. This is either because (i) a possible second oscillation is of such short duration that it is not pronounced within the sampling grid, (ii) it was not detected because its short duration in combination with a changed sedimentation rate led to its blurring in a mixed spectrum, (iii) a possible oscillation had no detectable influence in the region (as could be inferred from table 1 compiled by Usinger in the same publication), or (iv) the inferred oscillation at Kubitzbergmoor (Usinger 2004) reflects a natural succession subsequent to a local fire. Unfortunately, the latter cannot be proven right or wrong as Usinger did not record (or show) charcoal particles in pollen profiles. 
NAH-7a (Boreal a/ early Boreal period, $13.695-13.485$ m) 10,750 to 10,370 cal yr BP.

In the course of $\mathrm{NAH}-7 \mathrm{a}$, stable values of the organic sediment content and the $\mathrm{CaCO}^{3}$ sediment content are reached. While the reason for the strong initial fluctuation of $\mathrm{CaCO}^{3}$ content remains unclear, a constant forest cover with a closed canopy requires stable and continuous input of organic material.

The general pollen concentration values increase strongly, but display a minimum of two samples revealing that all taxa are affected. The two samples belong to a preparation series in which the acetolysis was carried out over a prolonged time period (cf. NAH-5b). Therefore, this is unfortunately more an effect of preparation than an oscillation.

However, initially the AP/NAP ratio of 92/8 continues to indicate a very dense forest. Poaceae and ferns remain present in the undergrowth, while other herbs and heliophilous species have rarely been or not been recorded at all. The concentration values show a gradual shift in importance from Betula sp. (cf. B. pendula and B. pubescens) to Pinus sp. (cf. sylvestris), whereas the latter is increasingly dominant in the forest. Quercus sp. and Ulmus sp. now frequently appear within the pollen spectrum. Actual growth of these species in the area is likely (Nelle and Dörfler 2008; Overbeck 1975). In addition, Corylus sp. (cf. avellana) spreads gradually. The accelerated increase of the Corylus sp. curve towards the end of the assemblage zone indicates optimal growth conditions, even in the understory of the forest (Overbeck 1975; Theuerkauf et al. 2014; Wiethold 1997). The forest in turn reached close to the banks of the lake. Here, Sparganium sp. grows in shallow water. Aquatic plants include various species of Myriophyllum.

NAH-7b (Boreal b/ mid-late Boreal, 13.485 - 12.740 m) 10,370 to 8,900 cal yr BP. The assemblage zone encompasses the deposition of the Saksunarvatn Ash (Krüger \& van den Bogaard, in prep.). The diffuse distribution of the shards reveals that to a certain extent rearrangement probably masked also the palynological record. For this reason, a possible environmental impact of the Saksunarvatn ash cannot be considered (Zanon in prep.). However, it is striking that the reconstructed depth of the cryptotephra layer correlates with the main increasephase of Corylus sp. Thus the tephra can be used as a stratigraphic time marker for a European comparison.

Concentration values rise again to an average of $3.3 \times 10^{3}$ and partly even $13 \times 10^{3}$ grains per $\mathrm{cm}^{3}$ sediment. Here, Pinus sp. is the dominant tree species. Quercus sp. is considered a potential part of the forest in which Ulmus sp. continues to spread slowly. In combination with especially Corylus sp. Betula (cf. pubescens and pendula) is successively displaced. The maximum of Corylus sp. values 
reflects the characteristic Boreal hazel maximum (Averdieck 1957; Firbas 1949; Giesecke et al. 2011; Overbeck 1975).

However, the spread of Corylus sp. is much less pronounced than in adjacent areas. Propagation may depend predominately on edaphic factors and less on a potential promotion by humans, as first stated by Firbas (1949) and recently shown by Theuerkauf et al. (2014) or Zanon in Groß et al. (2019). Grasses and a few herbs, including Urtica sp. (cf. dioica) and ferns (Polypodium indet.) constituted the undergrowth of the pine, hazel and birch forest. In turn, Empetrum sp. and Calluna sp. are no plausible components here due to their considerable demand for light (Ellenberg et al. 2001). It is more likely that the continuous record of both pollen types suggests that (i) there may have been few open spots in the forest, or (ii) that together with, for example, Cyperaceae and Sphagnum sp. they were part of a bog vegetation at the terrestrialised former banks of a subsequent incision lake. Still the forest reached close to the banks of the lake. Here, Typha latifolia and Sparganium sp. thrived. In deeper waters Myriophyllum sp. and Nymphaea sp. were present.

Disturbances in the forest are mainly caused by fires, as the record of micro charcoal particles documents. Fires occurred frequently, potentially controlled by drier climatic conditions and promoted by the high proportion of Pinus sp. in the forest (Rickert 2003). However, a fire event in the immediate vicinity of the lake can be ruled out, as no opening or succession as a result of a fire is apparent in the course of NAH-7b.

\section{3 temporal scale of environmental transformations}

The most fundamental environmental changes observable in the record is the transition from tundra to woodland. In fact this shift occurred twice within the record (during the Lateglacial and very Early Holocene).

A variety of pollen profiles from northern Europe, especially from Schleswig-Holstein, suggest that there are various similarities in the primary succession of the early Allerød period and the early Preboreal period. The palynological features of both transition phases (Dryas-1-early Allerød transition and Dryas-3-Preboreal transition) overlap considerably. This includes that pollen of the tree birch type (Betula pubescens-type) show rapid increases, which, especially in northern Schleswig-Holstein, is often preceded by a short phase of a pronounced Juniperus pollen abundance (Schütrumpf 1943; Schütrumpf 1958; Usinger 1975; 1981b; Usinger and Wolf 1982). The same is reflected in the present record.

Obviously, similarities between the early Allerød period and the Preboreal period do not mean that the actual alteration of the vegetation is identical. In fact, they differ significantly (compare e.g. NAH4a and $\mathrm{NAH}-6 \mathrm{a})$. Furthermore, it is evident that similarities also depend on sedimentation rate, sampling strategy, preservation of archives as well as their size. However, changes are undeniable 
and the questions are, (i) can we delimitate the temporal dimension of these environmental transformations, and (ii) how can we evaluate the degree of alteration in order to compare these transformations?

A general difficulty with such a comparison is, that it contrasts two constantly progressing primary successions of different pace, which in turn are linked to different factors. These in particular include local conditions such as available soils and, above all, the presence of species or distances to refugial sites. However, if one addresses certain pollen analytical features which are compared to each other, it is possible to define the temporal scale to some extent (table 1; fig. $6 a$ and b).

Both periods are preceded by a phase in which stadial vegetation prevailed and in which the pollen spectrum was dominated by NAP. The pre-woodland phase (Vorwaldphase) with increased, partly maximum Juniperus values precedes the Betula-rise of the Allerød period and occurs around 13,890 cal yr BP. A few decades later, around 13,850 cal yr BP, Betula pollen values display steep increases. In contrast to that, the pre-woodland phase, measured by the concentration values, was even more pronounced during the early Preboreal period, but it already coincided with the Betula-rise around 11,550 cal yr BP. This coincidence can in turn be explained by more favourable local conditions (prepared soils), as well as by the fact that populations of Betula pubescens survived the Dryas 3 period locally, whereas they first needed to migrate from southern stands during the early Allerød period.

The steep rise of Betula pubescens-type pollen values in both periods corresponds to a clearly decreasing percentage of NAP. This steep increase of the early Allerød period terminated around $13,740 \mathrm{cal} y r$ BP. In the course of the Preboreal period it reached maximum values around $11,450 \mathrm{cal}$ yr BP. Consequently, both phases have a strikingly correlating duration of about 100 years $(11,550$ to 11,450 cal yr BP) or 110 years (13,850 to 13,740 cal yr BP).

This temporal coincidence is deceptive. Within a similar time period the concentration values in early Allerød increase from 1000 to 3000 pollen $/ \mathrm{cm}^{3}$ sediment. In clear contrast, during the early Preboreal period they rose from 2000 to 29.000 pollen $/ \mathrm{cm}^{3}$ sediment. It must be clear that this is in turn controlled by multiple further factors, however, this alone illustrates that an environmental change was potentially much more profound during the Early Holocene - judged by modern perception at least.

However, in both periods the actual change of the environment is not finished with the termination of the steep rise of Betula pubescens-type pollen. During the mid Allerød period (Allerød 3, around 13,480 cal yr BP), following the cooler period of Dryas 2, finally an open woodland developed. 
In the Preboreal period a forest development - here probably attenuated by the PBO - is detected at about 11,250 cal yr BP. At this time, there are scarcely any pollen of shade-intolerant species left in the pollen spectrum.

Again, an approximatively temporal correlation of about 370 years (13,850 to 13,480 cal yr BP) to 300 years $(11,550$ to 11,250 cal yr BP) is apparent. And again, a coincidence is deceptive as the pace of actual vegetation change within this time frame is different.

The preboreal Betula rise can be compared in many pollen profiles with the rise of the early Allerød period. However, there are clear indications that trees formed much denser populations during the Early Holocene. There are no representative pollen types of the open park tundra detectable in the course of the Preboreal period and closed curves of Artemisia and Empetrum rapidly terminate different to the mid Allerød period (Averdieck 1957; Overbeck 1975). When comparing these two developments, it must be clear that the pollen spectrum can appear almost equal, but at the same time they reflect very distinct levels of the primary succession - an open woodland for the mid Allerød period and a forest for the Preboreal period (for differentiation see 4.4).

This means that a comparison of apparently similar pollen features can be made on a temporal basis, but the actual speed of vegetation change is divergent. Initial points are in both cases pollen spectra that reflect tundra vegetation. But within a comparable temporal dimension no comparable actual development is reflected. This is particularly due to edaphic factors, the distance to refugial sites or the presence of species, as well as other factors that cannot be assessed, such as weather or exploitation by animals as well as people.

When intending to evaluate the degree of change it can be stated that in both cases the spread of trees must be regarded as fundamental. Here the question remains whether the appearance of the first trees should be considered as more profound, or the rapid rate at which birch trees (and of course others as Pinus sylvestris, Betula pendula, or Populus tremula) spread during early Preboreal period.

\section{4 correlation to key sites - the bridging function}

Following Litt and Stebich (1999) Schleswig-Holstein forms a bridge between central European and Scandinavian pollen records with regard to biostratigraphic correlation. This fact can be demonstrated on the basis of the first evidence of tree birches (in this case Betula pubescens) as well as the development of denser woodlands and forests along a transect across the North European Plain. For this purpose the records of Slotseng (SLO) (Mortensen et al. 2011) and lake Hämelsee (HÄM) (Merkt and Müller 1999) are selected for a comparison with the here presented record (table 2; fig. 7). All records contain high-resolution analyses of pollen as well as additionally botanical macrofossils and deal with Lateglacial limnic deposits. The distance between two locations is 
approximately equal ( $150-200 \mathrm{~km}$; fig. 5). Nevertheless, it should be noted that the result may be slightly biased, as the HÄM record does not differentiate between Betula pubescens-type and $B$. nana-type pollen.

The comparison is mainly based on biostratigraphy. However, a range of calibrated radiocarbon dates are additionally provided for the corresponding steps of vegetation development. Within these steps a differentiation is made between open woodland (Betula pubescens-type pollen/AP 70\%, grasses and herbs $\geq 20 \%$, heliophilous grasses and herbs present, few or no shade tolerant species), dense woodland (Betula pubescens-type pollen/AP $>75 \%$, grasses and herbs $\leq 15 \%$, heliophilous grasses and herbs rare, few shade tolerant species) and forest (AP $>85 \%$, grasses and herbs $<10 \%$, heliophilous grasses and herbs absent, shade tolerant species present).

Within the most southern record (HÄM) first macrofossils of Betula pubescens already occur in sediments deposited during the Meiendorf period (here between 14,200 and $13,800 \mathrm{cal}$ yr BP). However, as Merkt and Müller (1999) mentioned redeposition of pollen in corresponding depths, this needs to be considered for Betula pubescens macrofossils as well.

From the early Allerød period (referred to as Bølling by Merkt and Müller (1999)) the character of the vegetation can be described as an open woodland (here between 13,650 and 13,500 cal yr BP). Here, Betula pubescens fruits are abundant and hence represent a terminus ante quem concerning the migration of tree birches. In sediments deposited at about the same biostratigraphic period the first appearance of Betula pubescens macrofossils (here around 13,770 cal yr BP) occur in the NAH record. In turn, first macrofossils of Betula pubescens are recorded in SLO in the course of the mid Allerød period (here around 13,500 cal yr BP).

If the Gerzensee oscillation is taken as a time marker $(13,120$ to 12,880 cal yr BP following Andersen et al. (2000); HÄM: 13,100 to 12,950 cal yr BP; NAH: 13,115 to 13,030 cal yr BP; SLO: 13,150 to 12,950 cal yr BP), a forest is already reflected in the HÄM record prior to that, while an open woodland can be inferred from the NAH record during this phase of the Allerød period. Until the late Allerød period a dense woodland is established in the area surrounding the Nahe palaeolake (here between 13,000 and 12,750 cal yr BP). In SLO the environment of the late Allerød is described as a heterogeneous landscape with open areas and stands of open woodland. In HÄM birches started to spread so rapidly during the early Preboreal period that they directly formed forests by about 11,600 cal yr BP. Also in NAH a forest developed early in the Preboreal period (here between 11,530 and $11,450 \mathrm{cal}$ yr BP) due to the fact that tree birches survived the Dryas-3 period forming riparian woodlands in the area. This, however, is not the case for SLO. A development of a dense woodland and later of a forest was delayed at SLO during the Preboreal period because tree birches did not survive the Dryas-3 period locally (Mortensen et al. 2011). 
This comparison, although simplistic, clearly demonstrates the value of the NAH record as being an important connection between Northern European and Central European pollen records. In addition, it emphasizes the fact that meaningful results can only be achieved if both biostratigraphic units and absolute dating is included. Nevertheless, it is essential that absolute dating does not concern the temporal delimitation of biostratigraphic units and their spatial comparison, but rather the temporal framework of specific phases or palynological features, which can be completely different in different geographical locations.

\section{5 considering charcoal particles of the palynological record}

In this paper, the interpretation of a wildfire within the catchment area is based on the assumption that a successional cycle occurs subsequently to a fire event, which in turn is reflected in the palynological record at a sufficient resolution (Green 1982). This applies to the charcoal peak (NAH4c4) discussed above. In this case, the increased charcoal concentration cannot be reasonably explained by redeposition either, as no corresponding erosion indicators are recorded. In addition, a specific taxon that is common after fires (Epilobium cf. angustifolium) (Keeley and Keeley 1987) is involved in the vegetative succession. For this reason, the characteristics can be compared with further suspected fires, even under the premise that potential fires of different vegetation types are confronted.

A further basic criterion for the identification of fire regimes adjacent to the investigated archive is the simultaneous occurrence of charcoal particles of different size classes (larger than $50 \mu \mathrm{m}$ ) that correlate with increased total charcoal concentration. The size and thus the weight of the particles determines the distance of transport (Clark 1988) - even if they are generally distributed like pollen and local, regional and supra-regional components need to be considered (Fægri and Iversen 1989; Patterson et al. 1987). Based on the record, this results in three phases for the last part of the Lateglacial and the Early Holocene transition that need a closer examination (NAH-5a [2], NAH-5b [3], NAH-6a [4]; for environmental contextualization see 4.2.). They are compared to the identified wildfire [1] recorded in NAH-4c4 in table 3.

On the basis of this comparison, it can be concluded that multiple reasons could be responsible for the charcoal input. [2] coincides with [1] in the period of increased dryness and extensive wildfires (Crombé 2016; Hoek 1997; Kaiser 2003; Kaiser et al. 2009; Tolksdorf et al. 2014; Van der Hammen and Van Geel 2008). It is possible that they both reflect regional fires from the catchment (or further away), whereby a potential succession is masked by the input of pollen from the local and regional vegetation. It is equally plausible that long-distance input contributed to the total concentration in 
the sediment and the prolonged record is an effect of continuous rearrangement (Wolbach et al. 2018).

[3] falls into a period of increased oceanity and thus stronger humidity (Overbeck 1975; Usinger and Wolf 1982). Intensive forest fires over large areas of Europe are no longer proven and hence, increased charcoal input from long-distance flight is rather unlikely. Secondary deposition of earlier charcoal inputs is possible, as e.g. indicated by the persisting record of erosion and rearrangement indicators (Wolbach et al. 2018). Fire of anthropogenic origin is likewise probable, as human activity is archaeologically (typologically and by ${ }^{14} \mathrm{C}$ data) documented near-site (Wild 2017). The most plausible explanation is again a mixture of different sources. Nevertheless, human-environmentinteraction must be considered as an additional and significant component of the total charcoal concentration.

Finally, [4] lies in a phase of strong environmental transformations with increased precipitation and the rapid spread of a birch forest in the area. However, rearrangement indicators are not well represented. The increasingly dense vegetation renders it rather unlikely that terrestrially deposited charcoal particles are washed into the lake (see NAH-6a). Here, fires of anthropogenic origin are most probable as human activity is archaeologically documented (Wild 2017).

These interpretations are of course simplistic. However, it is generally noticeable that charcoal input is at its highest (at [3] and [4]) when (i) no reaction of the vegetation is detectable, (ii) erosion indicators are present at rather low levels, (iii) the high humidity suggests that extensive wildfires are not impossible but rather implausible, and (iv) at the same time human presence is archaeologically proven. Here, this can at least be considered as an emerging and interesting pattern.

\section{Conclusion}

This article presents the first complete pollen profile that covers the Lateglacial and Early Holocene in the area of Schleswig-Holstein, Germany. The particular strength lies in the fact that (i) the investigated sediments are not interrupted by the prominent hiatus at the Allerød-Dryas 3 transition (Usinger 1981a), (ii) the record comprises the first Lateglacial annually laminated sediments of Schleswig-Holstein, which (iii) in combination with radiocarbon dated botanical macrofossils and three cryptotephra layers provide excellent age control (Dreibrodt et al., in prep.; Krüger \& van den Bogaard, in prep.). Therefore, (iv) it is possible to integrate the record into the existing event stratigraphy and to compare it with important European key sites. Thus the record fills multiple previously existing desiderata.

Due to the good chronological resolution, emphasis is given to the temporal scale of environmental transformation. A comparison of apparently similar pollen features (here the Betula pubescens-type 
pollen curve at the Dryas 1-Allerød transition and at Dryas 3-Preboreal transition) can be made on a temporal basis, but the actual speed of vegetation change is divergent. Within a comparable temporal dimension different steps of the primary succession are reached that in turn are not as different when looking at the pollen spectrum and percentage diagram alone. This highlights how challenging and complex it is to compare seemingly resembling alterations of the vegetation and their characteristics even within one record.

Schütrumpf (1955) as well as Litt and Stebich (1999) already emphasized that palynological records of the Lateglacial from the area of present-day Schleswig-Holstein have an important bridging function. This is particularly evident in the comparison of Central and Northern European pollen profiles. A comparison with the records from Lake Hämelsee (Merkt and Müller 1999) and Slotseng (Mortensen et al. 2011) further illustrates this assumption. As could be shown by the migration and dispersal of Betula pubescens, the data set of the Nahe palaeolake fits perfectly into existing records and thus refines our understanding of the vegetation history on a spatial and temporal level. In this respect, a locally occurring peculiarity is e.g. unusually high Helianthemum sp. values during the Meiendorf and Dryas 1 periods respectively. Regarding general tendencies of the vegetation development the presented pollen profile is consistent with the majority of local and regional records (Bock et al. 1985; Bokelmann et al. 1983; Menke 1968; Schütrumpf 1935; 1936; 1937; 1943; 1958; Usinger 1975; 1981b; 1981c; 1985; 1998; Usinger and Wolf 1982).

Archaeological and palynological research have always been closely interlinked, especially in northern Germany. This paper also keeps this tradition, as the coring location is very close to a Palaeolithic site (Wild 2017). Thus it is possible to discuss human action and its reflection in the palynological record long before classical human indicators occur. In this context, it could be demonstrated that high charcoal particle concentrations especially at the transition from the Pleistocene to the Holocene can be explained with high probability by human action. This is of particular interest, in the light of the find region of the Ahrensburg tunnel valley, which lies only 18 kilometres to the south. 


\section{Acknowledgements:}

This article is part of a dissertation within project B1 (Pioneers of the North, PI: B.V. Eriksen) of the CRC 1266, Scales of Transformation. We are thankful to Svetlana Ibens and Carola Floors for support with chemical preparation processes, as well as Ingo Feeser, Ingo Clausen and Sonja B. Grimm for valuable suggestions. Funded by the Deutsche Forschungsgemeinschaft (DFG, German Research Foundation - Projektnummer 2901391021 - SFB 1266).

\section{References}

Aletsee L (1959) Zur Geschichte der Moore und Wälder des nördlichen Holsteins. Barth, Leipzig Andersen CS, Björck S, Bennike O, Heinemeier J, Kromer B (2000) What do D14C changes across the Gerzensee oscillation/GI-1b event imply for deglacial oscillations? Journal of Quaternary Science 15

Averdieck F-R (1957) Zur Geschichte der Moore und Wälder Schleswig-Hosteins. Ein Beitrag zur Frage der Rekurrenzflächen vol Bd. 19. Nova Acta Leopoldina N.F. 130.

Averdieck F-R, Erlenkeuser H, Willkom H (1972) Altersbestimmungen an Sedimenten des Großen Segeberger Sees Schriften Naturwissenschaftlicher Verein Schleswig-Holstein 42:47-57

Bakke J et al. (2009) Rapid oceanic and atmospheric changes during the Younger Dryas cold period Nature Geoscience 2:202 doi:10.1038/ngeo439

Bakker M, van Smeerdijk DG (1982) A palaeoecological study of a late holocene section from "Het Ilperveld", western Netherlands Review of Palaeobotany and Palynology 36

Behre K-E (1966) Untersuchungen zur spätglazialen und frühpostglazialen Vegetationsgeschichte Ostfrieslands Eiszeitalter und Gegenwart 17:69-84

Behre K-E (1981) The Interpretation of Anthropogenic Indicators in Pollen Diagrams Pollen et Spores 23:225-245

Behre K-E (1986) Anthropogenic indicators in pollen diagrams. Bremerhaven

Bejerinck W (1976) Zadenatlas Der Nederlandsche Flora. Ten Behoeve van de Botanie, Palaeontologie, Bodemcultuur en Warenkennis. Amsterdam

Bennett B (2001) What is a forest? On the Vagueness of Certain Geographic Concepts Topoi 20:189201

Bennett KD, Tzedakis PC, Willis KJ (1991) Quaternary refugia of north European trees Journal of Biogeography 18:103-115

Bennike O, Jensen JB (1995) Near-shore Baltic Ice Lake deposits in Fakse Bugt, southeast Denmark Boreas 24:185-195

Bennike O, Sarmaja-Korjonen K, Seppänen A (2004) Reinvestigation of the classic late-glacial Bølling Sø sequence, Denmark: chronology, macrofossils, Cladocera and chydorid ephippia Journal of Quaternary Science 19:465-478

Beug H-J (2004) Leitfaden der Pollenbestimmung für Mitteleuropa und angrenzende Gebiete.

Birks HH, Birks HJB (2000) Future uses of pollen analysis must include plant macrofossils Journal of Biogeography 27

Birks HH, Larsen E, Birks HJB (2005) Did tree-Betula, Pinus and Picea survive the last glaciation along the west coast of Norway? A review of the evidence, in light of Kullman (2002) Journal of Biogeography 32:1461-1471

Birks HJB (1968) The Identification of Betula nana pollen New Phytologist 67

Birks HJB, Birks HH (2008) Biological response to rapid climate change at the Younger Dryas-Holocene transition at Kråkenes, western Norway The Holocene 18:19-30

Björck S, Rundgren F, Ingolfsen O, Funder S (1997) The Preboreal oscillation around the Nordic Seas: terrestrial and lacustrine responses Journal of Quaternary Science 12:11 
Björck S, Walker MJC, Cwynar LC, Johnsen S, Knudsen KL, Lowe JJ, Wohlfarth B (1998) An event stratigraphy for the Last Termination in the North Atlantic region based on the Greenland ice-core record: a proposal by the INTIMATE group Journal of Quaternary Science 13:10

Blockley SPE et al. (2014) Tephrochronology and the extended intimate (integration of ice-core, marine and terrestrial records) event stratigraphy 8-128 ka b2k Quaternary Science Reviews 106

Bock W, Menke B, StrehI E, Ziemus H (1985) Neuere Funde des Weichselspätglazials in SchleswigHolstein Eiszeitalter und Gegenwart 35:20

Bokelmann K, Heinrich D, Menke B (1983) Fundplätze des Spätglazials im Heinholz-Esinger Moor, Kreis Pinneberg. Archäologische Befunde in Festschrift für Hans Hingst zum 75. Geburtstag Offa - Berichte und Mitteilungen zur Urgeschichte, Frühgeschichte und Mittelalterarchäologie 40:199-227

Bos JAA (1998) Aspects of Lateglacial-Early Holocene Vegetation Development in Western Europe. Palynological and palaeobotanical investigations in Brabant (The Netherlands) and Hessen (Germany). LPP Contributions series No 10. Utrecht

Bos JAA et al. (2018) Weichselian Lateglacial environmental and vegetation development in the Moervaart palaeolake area (NW Belgium); implications for former human occupation patterns Review of Palaeobotany and Palynology 248

Bos JAA, Janssen CR (1996) Local Impact of Palaeolithic Man on the Environment During the End of the Last Glacial in the Netherlands Journal of Archaeological Science 23:731-739

Bos JAA, Urz R (2003) Late Glacial and early Holocene environment in the middle Lahn river valley (Hessen, central-west Germany) and the local impact of early Mesolithic people?pollen and macrofossil evidence Vegetation History and Archaeobotany 12:19-36 doi:10.1007/s00334003-0006-7

Bos JAA, Van Geel B, Groenewoudt BJ, Lauwerier RCGM (2005) Early Holocene environmental change, the presence and disappearance of early Mesolithic habitation near Zutphen (The Netherlands) Vegetation History and Archaeobotany 15:27-43

Brandt I (1954) Late-glacial Macroscopic Plant Remains from Böllingsö Danm geol Unders II:3

Bratlund B (1993) Ein Riesenhirschschädel mit Bearbeitungsspuren aus Lüdersdorf, Kreis Grevesmühlen Offa - Berichte und Mitteilungen zur Urgeschichte, Frühgeschichte und Mittelalterarchäologie 49/50:7-14

Bratlund B (1996) Hunting Strategies in the Late Glacial of Northern Europe: A Survey of the Faunal Evidence Journal of World Prehistory 10:1-48

Brauer A, Endres C, Günter C, Litt T, Stebich M, Negendank JFW (1999) High resolution sediment and vegetation responses to Younger Dryas climate change in varved lake sediments from Meerfelder Maar, Germany Quaternary Science Reviews 18:321-329

Brauer A, Haug GH, Dulski P, Sigman DM, Negendank JFW (2008) An abrupt wind shift in western Europe at the onset of the Younger Dryas cold period Nature Geoscience 1:520-523

Broecker WS (2006) Abrupt climate change revised Global and Planetary Change 54:211-215

Bronk Ramsey C et al. (2015) Improved age estimates for key Late Quaternary European tephra horizons in the RESET lattice. Quaternary Science Reviews 118:18-23

Broström A et al. (2008) Pollen productivity estimates of key European plant taxa for quantitative reconstruction of past vegetation: a review Vegetation History and Archaeobotany 17:461478 doi:10.1007/s00334-008-0148-8

Caldwell MM (1987) Plant Architecture and Resource Competition. In: Schulze ED, Zwölfer H (eds) Potentials and Limitations of Ecosystem Analysis. Ecological Studies (Analysis and Synthesis), vol 61. Springer, Berlin, Heidelberg,

Cappers RTJ, Bekker RM (2013) A manual for the identification of plant seeds and fruits. Groningen archaeological studies. Groningen

Caruso Fermé L (2019) Methods of acquisition and use of firewood among hunter-gatherer groups in Patagonia (Argentina) during the Holocene Vegetation History and Archaeobotany 28:465479 
Chazdon RL et al. (2016) When is a forest a forest? Forest concepts and definitions in the era of frest and landscape restoration Ambia 45

Chrobok SM (1986) Ursachen und genetische Typen festländischer Kalkbildung periglaziärer und glaziär überformter Räume Zeitschrift für geologische Wissenschaften 14:277-284

Clark JS (1988) Particle Motion and the Theory of Charcoal Analysis: Source Area, Transport, Deposition and Sampling Quaternary Research 30:67-80

Crombé $P$ (2016) Forest fire dynamics during the early and middle Holocene along the southern North Sea basin as shown by charcoal evidence from burnt ant nests Vegetation History and Archaeobotany 25:311-321

de Groot WJ, Thomas PA, Wein RW (1997) Betula Nana L. and Betula Glandulosa Michx. Journal of Ecology 85:241-264

De Klerk P (2002) Changing vegetation patterns in the Endinger Bruch area (Vorpommern, NE Germany) during the Weichselian Lateglacial and Early Holocene Review of Palaeobotany and Palynology 119:35

De Klerk P (2004a) Confusing concepts in Lateglacial stratigraphy and geochronology: origin, consequences, conclusions (with special emphasis on the type locality Bøllings $\varnothing$ ) Review of Palaeobotany and Palynology 129:34

De Klerk P (2004b) Vegetation history and landscape development of the Friedländer Große Wiese region (Vorpommern, NE Germany) inferred from four pollen diagrams of Franz Fukarek Eiszeitalter und Gegenwart 54:71-94

De Klerk P (2008a) Patterns in vegetation and sedimentation during the Weichselian Late-glacial in north-eastern Germany Journal of Biogeography 35:1308-1322 doi:10.1111/j.13652699.2007.01866.x

De Klerk P (2008b) Patterns in vegetation and sedimentation during the Weichselian Late-glacial in north-eastern Germany Journal of Biogeography 35:15

De Klerk P et al. (2001) The Reinberg researches: palaeoecological and geomorphological studies of a kettle hole in Vorpommern (NE Germany), with special emphasis on a local vegetation during the Weichselian Pleniglacial/Lateglacial transition Greifswalder Geographische Arbeiten 23:43-131

De Klerk P, Helbig H, Janke W (2008a) Vegetation and environment in and around the Reinberg basin (Vorpommern, NE Germany) during the Weichselian late Pleniglacial, Lateglacial, and Early Holocene Acta Palaeobotanica 48:25

De Klerk P, Janke W, Kühn P, Theuerkauf M (2008b) Environmental impact of the Laacher See eruption at a large distance from the volcano: Integrated palaeoecological studies from Vorpommern (NE Germany) Palaeogeography, Palaeoclimatology, Palaeoecology 270:196214 doi:10.1016/j.palaeo.2008.09.013

Denton GH, Alley RB, Comer GC, Broecker WS (2005) The role of seasonality in abrupt climate change Quaternary Science Reviews 24:1159-1182

Donner JJ (1995) The Quaternary history of Scandinavia. World and Regional Geology vol 7.

Dörfler W (2017) Von der Dichte des naturnahen Waldes und den 'Flaschenhälsen' der Wildpopulation. In: Lechterbeck J, Fischer E (eds) Kontrapunkte. Festschrift für Manfred Rösch, vol 300. Universitätsforschungen zur prähistorischen Archäologie. Rudolf Habelt Verlag $\mathrm{GmbH}$, Bonn,

Dörfler W et al. (2012) A high-quality annually laminated sequence from Lake Belau, Northern Germany: Revised chronology and its implications for palynological and tephrochronological studies The Holocene 22:1413-1426 doi:10.1177/0959683612449756

Dreibrodt S, Krüger S, Weber J, Feeser I (in prep.) Limnological response to the Laacher See eruption (LSE) in an annually laminated Allerød sediment sequence from the Nahe palaeolake (northern Germany)

Edwards KJ (1990) Fire and the Scottish Mesolithic: Evidence from Microscopic Charcoal. In: Vermeersch PM, Van Peer P (eds) Contributions to the Mesolithic in Europe. Leuven University Press, pp 71-79 
Ellenberg H, Weber HE, Düll R, Wirth V, Werner W (2001) Zeigerwerte von Pflanzen in Mitteleuropa, 18 edn., Göttingen

Erdtman G (1960) The acetolysis method. A revised description Svensk Botanisk Tidskrift 39:4

Fægri K, Iversen J (1989) Textbook of Pollen analysis vol IV Edition. Leiden

Fernandes PM, Vega JA, Jiménez E, Eric R (2008) Fire resistance of European pines Forest Ecology and Management 256:246-255

Firbas F (1934) Über die Bestimmung der Walddichte und der Vegetation waldloser Gebiete mit Hilfe der Pollenanalyse Planta Archiv für wissenschaftliche Botanik 22:109-145

Firbas F (1937) Der pollenanalytische Nachweis des Getreideanbaus Zeitschrift für Botanik 31:447478

Firbas F (1949) Spät- und nacheiszeitliche Waldgeschichte Mitteleuropas nördlich der Alpen. vol 1. vol Allgemeine Waldgeschichte.

Firbas F (1954) Die Synchronisierung der mitteleuropäischen Pollendiagramme Danm geol Unders II Raekke Nr. 80:12-21

Fischer A, Mortensen MF, Henriksen PS, Mathiassen DR, Olsen J (2013) Dating the Trollesgave site and the Bromme culture - chronological fix-points for the Lateglacial settlement of Southern Scandinavia Journal of Archaeological Science 40:4663-4674

Fredskild B (1975) A late-glacial and early post-glacial pollen-concentration diagram from Langeland, Denmark Geologiska Föreningens i Stockholm Förhandlingar 97:151-161

Giesecke T et al. (2011) The pace of Holocene vegetation change - testing for synchronous developments Quaternary Science Reviews 30:2805-2814

Green DG (1982) Fire and stability in the postglacial forest of Nova Scotia Journal of Biogeography 9:29-40

Grimm EC (2000) Tilia 1.7.16 edn.,

Groß D et al. (2019) Adaptations and transformations of hunter-gatherers in forest environments: New archaeological and anthropological insights The Holocene Special Issue: Scales of Transformation - Human Environment Interaction in Prehistoric and Archaic Societies:1-14

Hallik R, Grube E (1954) Spät- und postglziale Gyttja im Altmoränengebiet von Elmshorn Neues Jahrbuch für Geologie und Paläontologie 7:315-322

Hartz N, Milthers V (1901) Det senglaciale Ler i Allerød Teglværksgrav Medd fra Dansk Geol Forening 8:30

Hedberg HD (1976) International Stratigraphic Guide. A guide to stratigraphic classification, terminology and procedure. John Wiley and Sons, New York, London, Sydney, Toronto

Heinisch O (1952) Die vordringlichsten Zuchtziele bei Sanddorn (Hippophaë rhamnoides L.) Der Züchter 22:144-147

Heiri O, Lotter AF, Lemcke G (2001) Loss on ignition as a method for estimating organic and carbonate content in sediments: reproducibility and comparability of results Journal of Paleolimnology 25:101-110

Hjelmroos M (1991) Evidence of long-distance transport of Betula pollen Grana 30:14

Hjelmroos M (1992) Long-distance transport of Betula pollen grains and allergic symptoms Aerobiologia 8:6

Hoek WZ (1997) Late-glacial and early Holocene climate events and chronology of vegetation development in the Netherlands Vegetation History and Archaeobotany 6:17

Hoek WZ (2001) Vegetation response to the 14.7 and 11.5 ka cal. BP climate transitions: is vegetation lagging climate? Global and Planetary Change 30:103-115

Hoek WZ (2008) The Last Glacial-Interglacial Transition Episodes 31:226-229

Hoek WZ (2009) Bølling-Allerød Interstadial. In: Gornitz V (ed) Encyclopedia of Paleoclimatology and Ancient Environments. Springer Netherlands, Dordrecht, pp 100-103. doi:10.1007/978-14020-4411-3_26

Hoek WZ, Bohncke SJP, Ganssen GM, Meijer T (1999) Lateglacial environmental changes recorded in calcareous gyttja deposits at Gulickshof, southern Netherlands Boreas 28

Horn HS (1971) The adaptive geometry of trees vol 3. Princeton University Press, Princeton 
Isarin RFB, Bohncke SJP (1999) Mean July Temperatures during the Younger Dryas in Northwestern and Central Europe as Inferred from Climate Indicator Plant Species Quarternary Research 51:158-173

Iversen J (1941) Landnam in Danmarks Stenalder: En pollenanalytisk unders $\varnothing$ gelse over det første landbrugs indvirking paa vegetationsudviklingen. vol 66. Danmarks Geologiske Undersøgelse. Kopenhagen

Iversen J (1942) En pollenanalytisk Tidfæstelse af Ferskvandslagene ved Nørre Lyngby Medd fra Dansk Geol Forening 10:23

Iversen J (1944) Helianthemum som fossil Glacialplante i Danmark Geologiska Föreningens i Stockholm Förhandlingar 66:774-776

Iversen J (1947) Plantevækst, Dyreliv og Klima i det senglaciale Danmark Geologiska Föreningens i Stockholm Förhandlingar 69:12

Iversen J (1954) The Late Glacial flora of Denmark and its relation to climate and soil. Danm geol Unders Række II:33

Iversen J (1973) The Development of Denmark's Nature since the Last Glacial Danmarks Geologiske Unders $\varnothing$ gelse. Kopenhagen

Jahns S (2000) Late-glacial and Holocene woodland dynamics and land-use history of the Lower Oder valley, north-eastern Germany, based on two, AMS 14C-dated, pollen profiles Vegetation History and Archaeobotany 9:111-123

Jankovská V, Komárek J (2000) Indicative Value of Pediastrum and Other Coccal Green Algae in Palaeoecology Folia Geobotanica 35:59-82

Janssen CR (1972) Local and regional pollen deposition. In: Birks HJB, West RG (eds) Quaternary Plant Ecology. The 14th Symposium of The British Ecological Society University of Cambridge, 2830 March 1972. Oxford London Edinburgh Melbourne, pp 31-42

Janssen CR (1984) Modern Pollen Assemblages and Vegetation in the Myrtle Lake Peatland, Minnesota Ecological Monographs 54:213-252

Johnson SJ et al. (1992) Irregular glacial interstadials recorded in a new Greenland ice core Nature 3:311-313

Jones $G$ et al. (2018) The Lateglacial to early Holocene tephrochonological record from Lake Hämelsee, Germany: a key site within the Eropean tephra framework Boreas 47:28-40

Kaiser K (2003) Geoarchäologie und landschaftsgeschichtliche Aussage spätpaläolithischer und frühmesolithischer Fundplätze in Mecklenburg-Vorpommern Meyniana 55:49-72

Kaiser K, Hilgers A, Schlaak N, Jankowski M, Kühn P, Bussemeier S, Przegietka K (2009) Palaeopedological marker horizons in northern central Europe: characteristics of Lateglacial Usselo and Finow soils Boreas 38:591-609

Kaplan JO, Pfeiffer M, Kolen JC, Davis BA (2016) Large Scale Anthropogenic Reduction of Forest Cover in Last Glacial Maximum Europe PLoS One 11:e0166726 doi:10.1371/journal.pone.0166726

Karlsdóttir L, Thórsson $\mathbb{E T}$, Hallsdóttir M, Sigurgeirsson A, Eysteinsson T, Anamthawat-Jónsson $\mathrm{K}$ (2007) Differentiating pollen of Betula species from Iceland Grana 46:7

Kasse C (1997) Cold-Climate Aeolian Sand-Sheet Formation in North-Western Europe (c.14-12.4 ka); a Response to Permafrost Degradation and Increased Aridity Permafrost and Periglacial Processes 8:295-311

Keeley JE, Keeley SC (1987) Role of fire in the Germination of chaparral Herbs and Suffrutescents Madroño 34:240-249

Kolstrup E (1982) Late-Glacial Pollen diagrams from Hjelm and Draved mose (Denmark) with a suggestion of the possibility of Drought during the earlier Dryas Review of Palaeobotany and Palynology 36:29

Komárek J, Marvan P (1992) Morphological Differences in Natural Populations of the Genus Botryococcus (Chlorophyceae) Archiv für Protistenkunde 141:65-100

Koste W (1980) Rotatoria. Die Rädertiere Mitteleuropas, begründet von Max Voigt., 2 edn., Stuttgart Krog H (1954) Pollen analytical investigation of a C14-dated Alleröd section from Ruds Vedby Danm geol Unders Række II:20 
Kromer B, Becker B (1993) German Oak and Pine 14C Calibration, 7200-9439 BC Radiocarbon 35:125135

Krüger S, Damrath M (2019) In search of the Bølling-Oscillation: a new high resolution pollen record from the locus classicus Lake Bølling, Denmark Vegetation History and Archaeobotany doi:https ://doi.org/10.1007/s0033 4-019-00736 -3)

Krüger S, Dörfler W, Bennike O, Wolters S (2017) Life in Doggerland - palynological investigations of the environment of prehistoric hunter-gatherer societies in the North Sea Basin Eiszeitalter und Gegenwart 66:3-13

Krüger S, Mortensen MF, Dörfler W (in prep.) Sequence completed - palynological investigations on Lateglacial/Early Holocene environmental changes recorded in sequentially laminated lacustrine sediments of the Nahe palaeolake in Schleswig-Holstein, Germany.

Krüger S, van den Bogaard C (in prep.) Small shards and long distances - three cryptotephra layers from the Nahe palaeolake including the first discovery of Laacher See Tephra in SchleswigHolstein (Germany)

Krüger S (in prep.) Of birches, smoke and reindeer dung - tracing human-environmental interactions palynologically in sediments from the Nahe palaeolake

Kuhry P (1997) The palaeoecology of a treed bog in western boreal Canada: a study based on microfossils, macrofossils and physico-chemical properties Review of Palaeobotany and Palynology 96:183-224

Lack AJ (1982) The ecology of flowers of chalk grassland and their insect pollinators Journal of Ecology 70:773-790

Lang G (1994) Quartäre Vegetationsgeschichte Europas. Gustav Fischer Verlag, Jena, Stuttgart, New York

Leroy SAG, Zolischka B, Negendank JFW, Seret G (2000) Palynological analyses in the laminated sediment of Lake Holzmaar (Eifel, germany): duration of lateglacial and Preboreal biozones Boreas 29

Litt T, Behre K-E, Meyer K-D, Stephan H-J, Wansa S (2007) Stratigraphische Begriffe für das Quartär des norddeutschen Vereisungsgebietes Eiszeitalter und Gegenwart 56:59

Litt T, Stebich M (1999) Bio- and chronostratigraphy of the lateglacial in the Eifel region, Germany Quaternary International 61:12

Lotter AF (1999) Late-glacial and Holocene vegetation history and dynamics as shown by pollen and plant macrofossil analyses in annually laminated sediments from Soppensee, central Switzerland Vegetation History and Archaeobotany 8:165-184

Lotter AF (2001) The palaeolimnology of Soppensee (Central Switzerland), as evidenced by diatom, pollen, and fossil-pigment analyses Journal of Paleolimnology 25:65-79

Lotter AF, Birks HJB, Eicher U, Hofmann W, Schwander J, Wick L (2000) Younger Dryas and Allerød summer temperatures at Gerzensee (Switzerland) inferred from fossil pollen and cladoceran assemblages Palaeogeography, Palaeoclimatology, Palaeoecology 159:13

Lotter AF, Eicher U, Siegenthaler U, Birks HJB (1992) Late-glacial climatic oscillations as recorded in Swiss lake sediments Journal of Quaternary Science 7:187-204

Lowe JJ et al. (2008) Synchronisation of palaeoenvironmental events in the North Atlantic region during the Last Termination: a revised protocol recommended by the INTIMATE group Quaternary Science Reviews 27

Mangerud J, Andersen ST, Berglund BE, Donner JJ (1974) Quaternary stratigraphy of Norden, a proposal for terminology and classification Boreas 3:19

Mangerud J, Lie SE, Furnes H, Kristiansen IL, Lømo L (1984) A Younger Dryas Ash Bed in Western Norway and Its Possible Correlations with Tephra in Cores from the Norwegian Sea and the North Atlantic Quaternary Research 21:85-104

Menke B (1968) Das Spätglazial von Glüsing. Ein Beitrag zur Kenntnis der spätglazialen Vegetationsgeschichte in Westholstein Eiszeitalter und Gegenwart 19:12

Merkt J, Müller H (1999) Varve chronology and palynology of the Lateglacial in Northwest Germany from lacustrine sediments of Hämelsee in Lower Saxony Quaternary International 6:19 
Merkt J, Müller H, Knabe W, Müller P, Weiser T (1993) The early Holocene Saksunarvatn tephra found in lake sediments in NW Germany Boreas 22:93-100

Miller RF, Wigand PE (1994) Holocene Changes in Semiarid Pinyon-Juniper Woodlands. Response to climate, fire, and human activities in the US Great Basin BioScience 44:465-474

Mingram J, Negendank JFW, Brauer A, Berger D, Hendrich A, Köhler M, Usinger H (2007) Long cores from small lakes-recovering up to $100 \mathrm{~m}$-long lake sediment sequences with a highprecision rod-operated piston corer (Usinger-corer) Journal of Paleolimnology 37:12

Moore PD, Webb JA, Collinson ME (1991) An Illustrated Guide to Pollen Analysis. Blackwell Scientific, London

Mortensen MF et al. (2011) Lateglacial vegetation development in Denmark - New evidence based on macrofossils and pollen from Slotseng, a small-scale site in southern Jutland Quaternary Science Reviews 30:17

Mortensen MF, Henriksen PS, Bennike O (2014a) Living on the good soil: relationships between soils, vegetation and human settlement during the late Aller $\varnothing \mathrm{d}$ period in Denmark Vegetation History and Archaeobotany 23:195-205 doi:10.1007/s00334-014-0433-7)

Mortensen MF, Henriksen PS, Christensen C, Petersen PV, Olsen J (2014b) Vegetation development in south-east Denmark during the Weichselian Late Glacial: palaeoenvironmental studies close to the Palaeolithic site of Hasselø Danish Journal of Archaeology 3

Müller H, Kleinmann A (1998) Palynologische Untersuchungen eines Sedimentprofiles aus dem Wollingster See Mitteilungen der AG Geobotanik Schleswig-Holstein und Hamburg 57:44-52

Nathorst AG (1891) Den arktiska florans forna utbredning i länderna öster om Östersjön Ymer XI:31

Nelle O, Dörfler W (2008) A summary of the late- and post-glacial vegetation history of SchleswigHolstein. In: Dengler J, Dolnik C, Trepel M (eds) Flora, Vegetation und Naturschutz zwischen Schleswig-Holstein und Südamerika - Festschrift für Klaus Dierßen zum 60. Geburtstag, vol 65. Mitteilungen der Arbeitsgemeinschaft Geobotanik in Schleswig-Holstein und Hamburg Neugebauer I et al. (2012) A Younger Dryas varve chronology from the Rehwiese palaeolake record in NE_Germany Quaternary Science Reviews 36:91-102

Nilsson T (1960) Ein neues Standardpollendiagramm aus Bjärsjöholmssjön in Schonen vol 56. Lund Odgaard BV (1994) The Holocene vegetation history of northern West Jutland, Denmark vol 14.

Odhiambo M, Routh J (2016) Does Black Carbon Contribute to Eutrophication of Large Lakes? Current Pollution Reports - Invited Commentary 2:236-238

Overbeck FT (1975) Botanisch-geologische Moorkunde unter besonderer Berucksichtigung der Moore Nordwestdeutschlands als Quellen zur Vegetations-, Klima- und Siedlungsgeschichte Wachholtz, Neumünster

Overbeck FT, Schneider S (1938) Mooruntersuchungen bei Lüneburg und Bremen und die Reliktnatur von Betula nana L. in Nordwestdeutschland Zeitschrift für Botanik 33:1-54

Patterson WA, Edwards KJ, Maguire DJ (1987) Microscopic Charcoal as a Fossil Indicator of Fire* Quaternary Science Reviews 6:3-23

Pausas JG (2015) Review: Bark thickness and fire regime Functional Ecology 29:315-327

Rasmussen SO et al. (2006) A new Greenland ice core chronology for the last glacial termination Journal of Geophysical Research 111:1-16

Rickert B-H (2003) Kleinstmoore als Archive für räumich hochauflösende landschaftgeschichtliche Untersuchungen - Fallstudien aus Schleswig-Holstein. Christian-Albrechts Universität

Riede F, Bazely O, Newton AJ, Lane CS (2011) A Laacher See-eruption supplement to Tephrabase: Investigating distal tephra fallout dynamics Quaternary International 246:134-144

Riede F, Grimm SB, Weber M-J, Fahlke JM (2010) Neue Daten für alte Grabungen - ein Beitrag zur spätglazialen Archäologie und Faunengeschichte Norddeutschlands Archäologisches Korrespondenzblatt 40:297-316

Rothmaler W (2017) Rothmaler - Exkursionsflora von Deutschland. Gefäßpflanzen: Grundband vol 21. Auflage. Jäger, Eckhard J. doi:10.1007/978-3-662-49708-1

Rust A (1943) Die alt-und mittelsteinzeitlichen Funde von Stellmoor. K Wachholtz, Neumünster Rust A, Gripp K (1937) Das altsteinzeitliche Rentierjägerlager Meiendorf. K Wachholtz, Neumünster 
Ruttner-Kolisko A (1980) The abundance and distribution of Filinia terminalis in various types of lakes as related to temperature, oxygen and food Hydrobiologia 73:169-175

Schmincke H-U, Park C, Harms E (1999) Evolution and environmental impacts of the eruption of Laacher See Volcano (Germany) 12,900 a BP Quaternary International 61:61-72

Schütrumpf R (1935) Pollenanalytische Untersuchungen der Magdalenien- und LyngbyKulturchichten der Grabung Stellmoor Nachrichtenblatt für Deutsche Vorzeit 11:8

Schütrumpf R (1936) Paläobotanisch-pollenanalytische Untersuchungen der paläolithischen Rentierjägerfundstelle von Meiendorf bei Hamburg Veröffentlichungen des Archäologischen Reichsinstitutes 1:1-54

Schütrumpf R (1937) Die Paläobotanisch-Pollenanalytische Untersuchung. In: Rust A (ed) Das Altsteinzeitliche Rentierjägerlager Meiendorf. Karl Wachholtz Verlag, Neumünster, pp 11-47

Schütrumpf R (1943) Die pollenanalytische Untersuchunge der Rentierjägerfundstelle Stellmoor in Holstein. In: Rust A (ed) Die alt- und mittelsteinzeitlichen Funde von Stellmoor. Karl Wachholtz Verlag, Neumünster, pp 6-45

Schütrumpf R (1955) Das Spätglazial Eiszeitalter und Gegenwart 6:11

Schütrumpf $R$ (1958) Die Mooruntersuchungen bei den Ausgrabungen am Pinnberg bei Ahrensburg in Holstein. In: Rust A (ed) Die Funde vom Pinnberg. Karl Wachholtz Verlag, Neumünster, pp 1725

Selsing $L$ (2018) People and fire management in South Norway during the Lateglacial Journal of Archaeological Science 18:239-271

Shaw J (1975) Sedimantary Successions in Pleistocene Ice-Marginal Lakes. In: Jopling AV, McDonald BC (eds) Glaciofluvial and Glaciolacustrine Sedimentation, vol 23. Society of Economic Paleontologists and Minaralogists, Tulsa, pp 281-303

Skogen A (1972) The Hippophaë rhamnoides Alluvial Forest at Leinöra, Central Norway. A Phytsociological and Ecological Study Det Kongelige Norske Videnskabers Selskab Skrifter 41972:1-115

Smed P (1998) Die Entstehung der dänischen und norddeutschen Rinnentäler (Tunneltälter) Glaziologische Gesichtspunkte Eiszeitalter und Gegenwart 48:1-18

Søgaard K, Christensen C, Mortensen MF (2018) Pollen analyses from lake, field and beach- ridge deposits in the vicinity of the Bronze Age settlement at Bjerre Enge, Thy. In: Bech J-H, Eriksen BV, Kristiansen K (eds) Bronze Age Settlement and Land-Use in Thy, Northwest Denmark, vol 1.

Stockmarr J (1971) Tablets with spores used in absolute pollen analysis Pollen et Spores XIII:7

Sugita S, Hicks S, Sormunen $\mathrm{H}$ (2010) Absolute pollen productivity and pollen-vegetation relationships in northern Finland Journal of Quaternary Science 25:724-736

Terberger T, De Klerk P, Helbig H, Kaiser K, Kühn P (2004) Late Weichselian landscape development and human settlement in Mecklenburg-Vorpommern (NE Germany) Eiszeitalter und Gegenwart 54:138-175

Theuerkauf M (2003) Die Vegetation NO-Deutschlands vor und nach dem Ausbruch des Laacher SeeVulkans (12880 cal BP) Greifswalder Geographische Arbeiten 29:143-189

Theuerkauf M, Bos JAA, Jahns S, Janke W, Kuparinen A, Stebich M, Joosten H (2014) Corylus expansion and persistent openness in the early Holocene vegetation of northern central Europe Quaternary Science Reviews 90:183-198

Theuerkauf M, Joosten H (2009) Substrate dependency of Lateglacial forests in north-east Germany: untangling vegetation patterns, ecological amplitudes and pollen dispersal in the past by downscaling regional pollen Journal of Biogeography 36

Theuerkauf M, Joosten H (2012) Younger Dryas cold stage vegetation patterns of central Europe climate, soil and relief controls Boreas 41:391-407

Theuerkauf M, Kuparinen A, Joosten H (2012) Pollen productivity estimates strongly dependend on assumed pollen dispersal The Holocene 23:14-24 
Tidelski F (1960) Pollenanalytische Untersuchung von voll -, spät- und postglazialen Ablagerungen aus dem Trentmoor und dem Brennacker (Krs. Plön) Schriften Naturwissenschaftlicher Verein Schleswig-Holstein 30:92-109

Tinner W et al. (2008) A 700-year palaeoecological record of boreal ecosystem responses to climatic variation from Alaska Ecology 89:739-743

Tipping R (1996) Microscopic Charcoal Records, inferred human activity and climate change in the Mesolithic of northernmost Scotland. In: Pollard T, Morrison A (eds) The early Prehistory of Scotland. Edinburgh, pp 39-61

Tolksdorf JF, Turner F, Kaiser K, Eckmeier E, Bittmann F, Veil S (2014) Potential of palaeosols sediments and archaeological features to reconstruct Late Glacial fire regimes in northern Central Europe - case study Grabow site and overview Zeitschrift für Geomorphologie 58:211-232

Tralau H (1963) The recent and fossil distribution of some boreal and arctic montane plants in Europe Arkiv för Botanik 5:533 - 582

Turner F, Pott R, Schwarz A, Schwalb A (2014) Response of Pediastrum in German floodplain lakes to Late Glacial climate changes Journal of Paleolimnology 52:293-310

Tzedakis PC, Emerson Bc, Hewitt GM (2013) Cryptic or mystic? Glacial tree refugia in northern Europe Trends in Ecology \& Evolution 28:696-704

Usinger H (1975) Pollenanalytische und stratigraphische Untersuchungen an zwei SpätglazialVorkommen in Schleswig-Holstein, 25 edn., Kiel

Usinger H (1978a) Bölling-Interstadial und Laacher Bimstuff in einem neuen Spätglazial-Profil aus dem Vallensgaard Mose/Bornholm. Mit pollen-größenstatistischer Trennung der Birken Geologicla Survey of Danmark Yearbook 1977:25

Usinger H (1978b) Pollen- und großrestanalytische Untersuchungen zur Frage des BöllingInterstadials und der spätglazialen Baumbirkeneinwanderung in Schleswig-Holstein. Mit einem neuen Diagramm aus der Eichholz-Niederung bei Heiligenhafen Schriften Naturwissenschaftlicher Verein Schleswig-Holstein 48:21

Usinger H (1981a) Ein weit verbreiteter Hiatus in spätglazialen Seesedimenten: Mögliche Ursache für Fehlinterpretation von Pollendiagrammen und Hinweis auf klimatisch verursachte Seespiegelbewegungen Eiszeitalter und Gegenwart 31:17

Usinger H (1981b) Pollen- und Großestanalysen an limnischem Spätglazial aus dem Scharnhagener Moor, Schleswig-Holstein Schriften Naturwissenschaftlicher Verein Schleswig-Holstein 51:21

Usinger H (1981c) Zur spät-und frühpostglazialen Vegetationsgeschichte der schleswig-holsteinischen Geest nach dem Pollen und Pollendichtediagramm aus dem Esinger Moor Pollen et Spores XXIII:45

Usinger H (1985) Pollenstratigraphische, vegetations- und klimageschichtliche Gliederung des "Bölling-Alleröd-Komplexes" in Schleswig-Holstein und ihre Bedeutung für die Spätglazial Stratigraphie in benachbarten Gebieten Flora 177:44

Usinger H (1998) Pollenanalytische Datierung spätpaläolithischer Fundschichten bei Ahrenshöft, Kr. Nordfriesland Archäologische Nachrichten aus Schleswig-Holstein 8:24

Usinger $\mathrm{H}$ Vegetation and climate of the lowlands of northern Central Europe and adjacent areas around the Younger Dryas - Preboreal transition - with special emphasis on the Preboreal oscillation. In: Terberger T, Eriksen BV (eds) Workshop of the U.I.S.P.P.-Commission XXXII, Greifswald, 2004. Hunters in a changing workd. Environment and Archaeology of the Pleistocene - Holocene Transition (ca. 11000 - 9000 B.C.) in Northern Central Europe.

Usinger H, Wolf A (1982) Zur vegetations- und klimageschichtlichen Gliederung des Alleröds nach Untersuchungen im Blixmoor und Kubitzbergmoor (Schleswig-Holstein) Schriften Naturwissenschaftlicher Verein Schleswig-Holstein 52:17

Van Asch N, Heiri O, Bohncke SJP, Hoek WZ (2012) Climatic and environmental changes during the Weichselian Lateglacial Interstadial in the Weeterbos region, the Netherlands Boreas 42

van den Bogaard P, Schmincke H-U (1984) The Eruptive center of the Late Quaternary Laacher See Tephra (*) Geologische Rundschau 73:933-980 
Van der Hammen T (1951) Late-Glacial flora and periglacial phenomena in The Netherlands. Leiden, Van der Hammen T, Van Geel B (2008) Charcoal soils of the Allerød-Younger Dryas transition were the result of natural fires and not necissarily the effect of an extra-terrestrial impact Netherlands Journal of Geoscience - Geologie en Mijnbouw 87:359

Van Geel B (1976) A palaeoecological study of Holocene peat bog sections, based on the analysis of pollen, spores and macro- and microscropic remains of fungi, algae, cormophytes and animals., Amsterdam

Van Geel B, Bohncke SJP, Dee H (1981) A Palaeoecological study of an Upper Late Glacial and Holocene Sequence from "De Borchert", The Netherlands Review of Palaeobotany and Palynology 31:367-448

Van Geel B, De Lange L, Wiegers J (1984) Reconstruction and Interpretation of the local vegetational succussion of a lateglacial deposit from Usselo (The Netherlands) based on the analysis of micro- and macrofossils Acta Botanica Neerlandica 33:535-546

Van Geel BC, G.R.; van der Hammen, T. (1989) Palaeoecology and Stratigraphy of the Lateglacial Type Section at Usselo (The Netherlands) Review of Palaeobotany and Palynology 60:105

Wallin J-E, Segerström U, Rosenhall L, Bergmann E, Hjelmroos M (1991) Allergic symptoms caused by long-distance transported birch pollen Grana 30:4

Weaver AJ, Saenko OA, Clark PU, Mitrovica JX (2003) Meltwater Pulse 1A from Antarctica as a Trigger of the Bølling-Allerød Warm Interval Science 299:1709-1713

Weber M-J, Grimm SB, Baales M (2011) Between warm and cold: Impact of the Younger Dryas on human behavior in Central Europe Quaternary International 242:277-301

Weckström K, Weckström J, Yliniemi L-M, Korhola A (2010) The ecology of Pediastrum (Chlorophyceae) in subarctic lakes and their potential as paleobioindicators Journal of Paleolimnology 43:61-73

Widén B (2018) Inheritance of glabrous plants in Helianthemum oelandicum var. oelandicum and spatial patterns of allele frequencies in local populations Plant Systematics and Evolution 304:1199-1219

Wiethold J (1997) Studien zur jüngeren postglazialen Vegetations- und Siedlungsgeschichte im östlichen Schleswig-Holstein - mit regionalen Pollendiagrammen aus dem Belauer See, Kr. Plön, dem Treßsee, Kr. Schleswig-Flensburg und dem Illewitter Moor, Kr. RendsburgEcckernförde. Christian-Albrechts Universität

Wild M (2017) $18 \mathrm{~km}$ Northwards - Zooarchaeological and Technological Analysis of the Ahrensburgian Assemblage from Nahe LA11 at Lake Itzstedt (Kr. Segeberg / D) Archäologisches Korrespondenzblatt 47:441-461

Willis KJ, Rudner E, Sümegi P (2000) The Full-Glacial Forest of Central and Southeastern Europe Quaternary Research 53:203-213

Willson CJ, Manos PS, Jackson RB (2008) Hydraulic traits are influenced by phylogenetic history in the drought-resistent, invasive genus Juniperus (Cupressaceae) American Journal of Botany 95:299-314

Wolbach WS et al. (2018) Extraordinary Biomass-Burning Episode and Impact Winter Triggered by the Younger Dryas Cosmic Impact $\sim 12,800$ Years Ago. 2. Lake, Marine, and Terrestrial Sediments The Journal of Geology 126

Woldstedt P (1935) Erläuterungen zur Geologisch-morphologischen Übersichtskarte des norddeutschen Vereisungsgebietes im Maßstab 1:1500000. Preußisch Geologische Landesanstalt, Berlin

Woldstedt P (1954) Das Eiszeitalter. Grundlinien einer Geologie des Quartärs. Erster Band. Die Allgemeinen Erscheinungen des Eiszeitalters. Ferdinand Enke Verlag, Stuttgart

Wright HEJ (1984) Sensitivity and response time of natural systems to climatic change in the late Quaternary Quaternary Science Reviews 3:91-131

Wulff S et al. (2013) Tracing Laacher See Tephra in the varved sediment record of Trzechowskie palaeolake in central Northern Poland Quaternary Science Reviews 76:129-139 
Wygal BT, Heidenreich SM (2014) Deglaciation and Human Colonization of Northern Europe Journal of World Prehistory 27:111-144

\section{Figure captions:}

Figure 1: Map of soil types in the area of Schleswig-Holstein.

Figure 2: Location of the Nahe palaeolake (a) and coring location and archaeological site (b). DEM based on LVermGeoSH.

Figure 3:

Figure 4a: Concentration diagram of selected taxa for the Lateglacial part of the record.

Figure 4b: Concentration diagram of selected taxa for the Holocene part of the record.

Figure 5: Map of southern Scandinavia and northern Germany with locations of the Nahe palaeolake (NAH) and pollen profiles as mentioned in the text. 1 - Allerød (Hartz and Milthers 1901); 2 - Bølling Sø (Iversen 1942; Krüger \& Damrath 2019); 3 - Slotseng (Mortensen et al. 2011); 4 - Scharnhager Moor (Usinger 1981b); 5 - Kubitzbergmoor (Usinger and Wolf 1982); 6 - Glüsing (Menke 1968); 7 Liether Moor (Bokelmann et al. 1983; Usinger 1981c); 8 - Stellmoor (Usinger unpubl.; Schütrumpf 1943); 9 - Reinberg basin (De Klerk et al. 2008a); 10 - Westrhauderfehn (Behre 1966); 11 - Hämelsee (Merkt and Müller 1999).

Figure 6a: Diagram showing pollen concentration, percentage of arboreal pollen sum based on TTP and shares of Betula pubescens-type pollen during the early to mid Allerød period of the NAH record. Diagram plotted on age scale for better correlation. Designation a-e refer to table 1.

Figure 6b: Diagram showing pollen concentration, percentage of arboreal pollen sum based on TTP and shares of Betula pubescens-type pollen during the early to mid Preboreal period of the NAH record. Diagram plotted on age scale for better correlation. Designation a-f refer to table 1.

Figure 7: Visual comparison of the Hämelsee record (HÄM - Merkt and Müller (1999)), the Slotseng record (SLO - Mortensen et al. (2011)) and the present study (NAH). All records are plotted on age scale for reasons of comparability. The black curve displays the arboreal pollen sum based on TTP, the grey curve displays shares of Betula pollen (HÄM, including B. nana-type pollen) or Betula pubescens-type pollen (NAH and SLO). Yellow dashed line indicates Gerzensee-Oscillation as given according to the authors. Dark grey bar marks time period of first occurrence of tree birch macrofossils in the records. Light green/ a: open woodland; middle green/ b: dense woodland; dark green/ c: forest. 
Figure 1

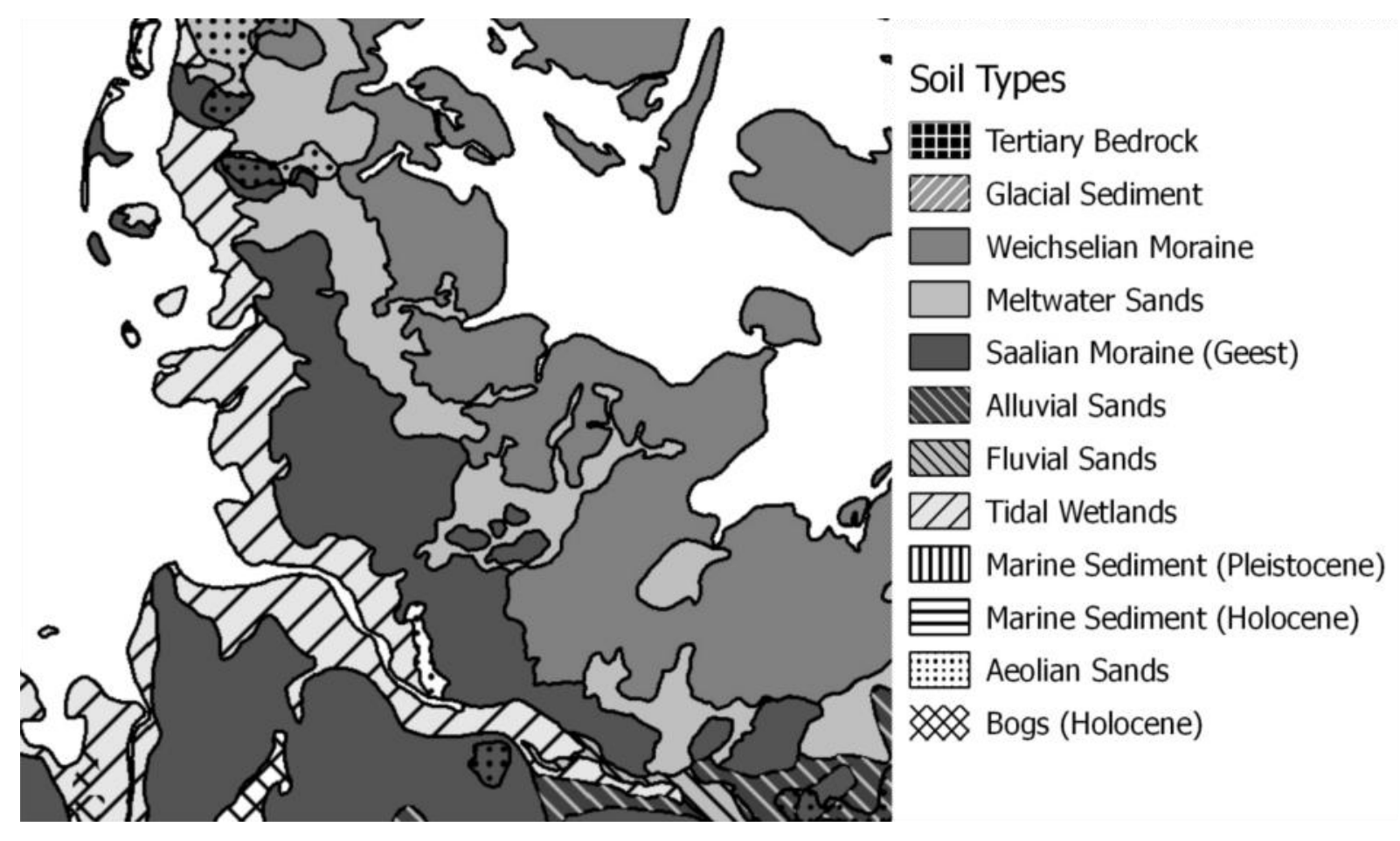

Figure 2

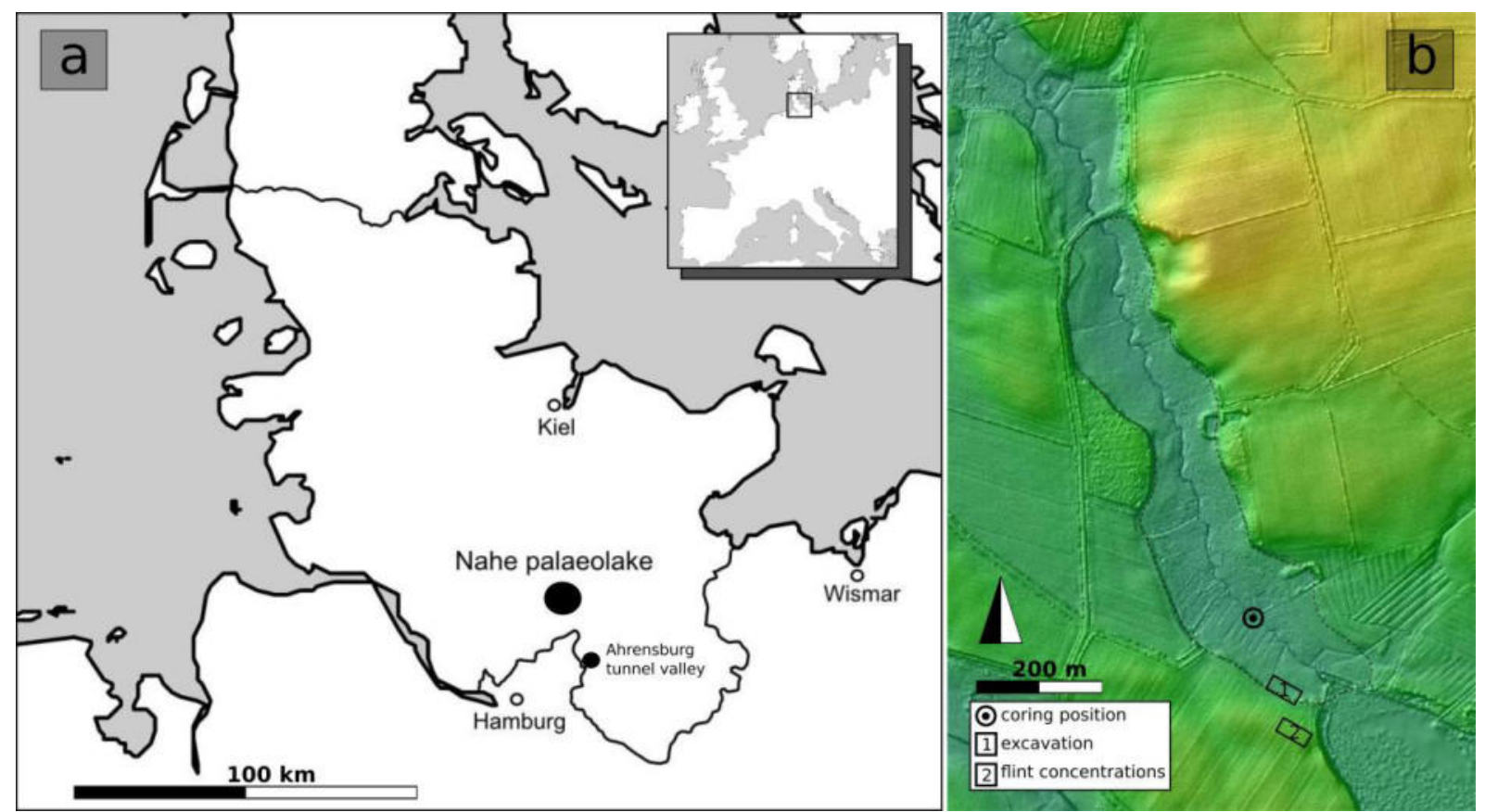




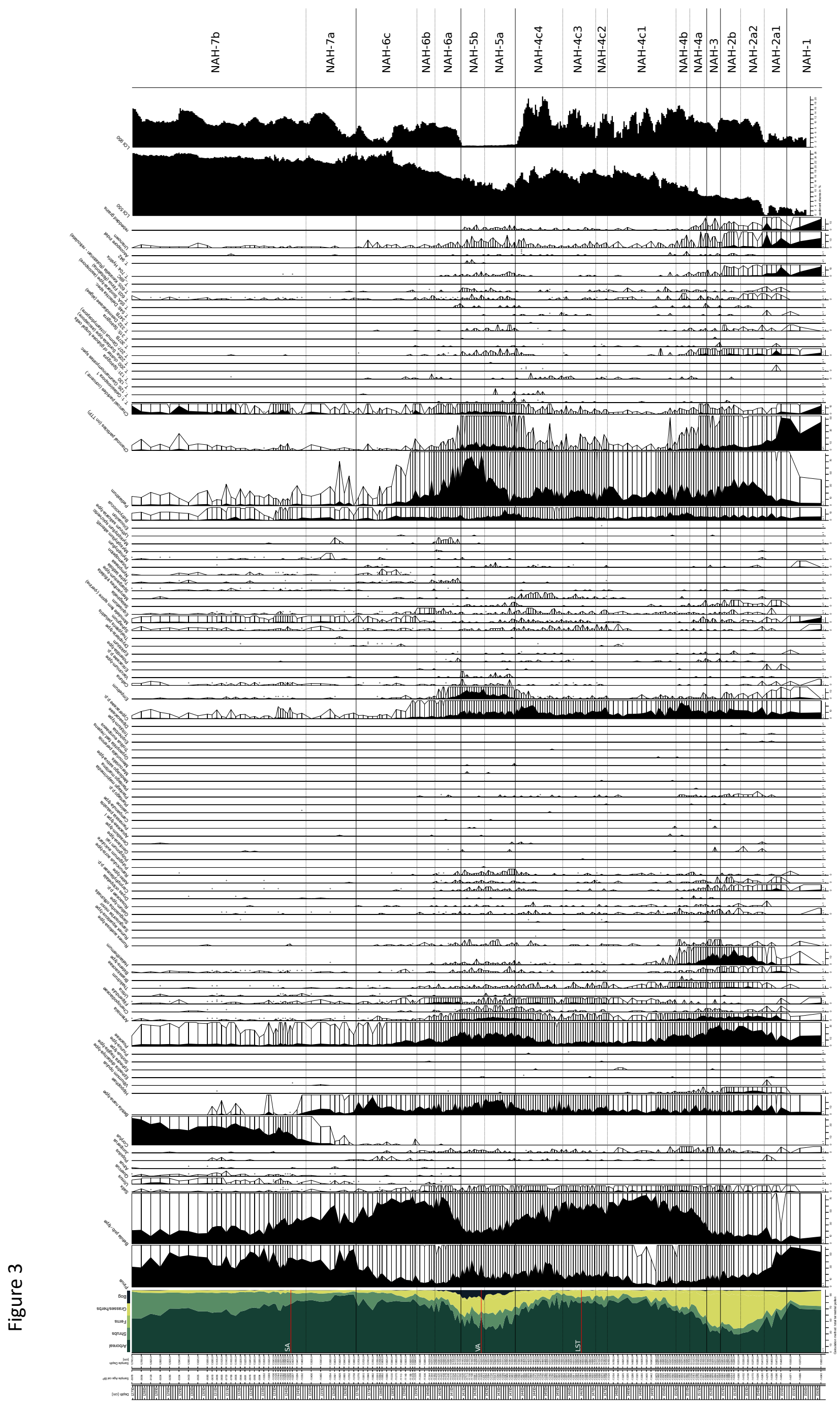


Figure 4a:

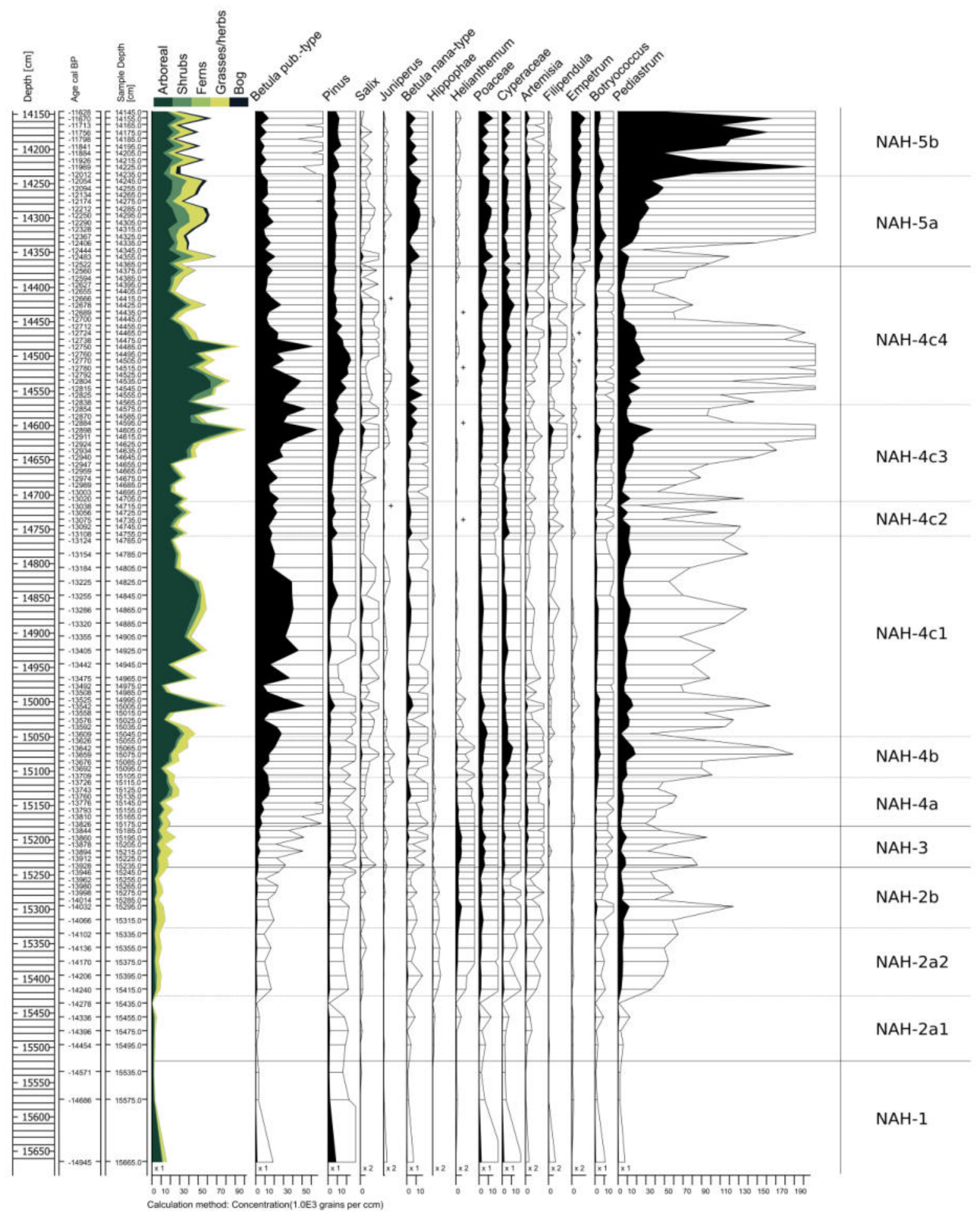


Figure 4b:

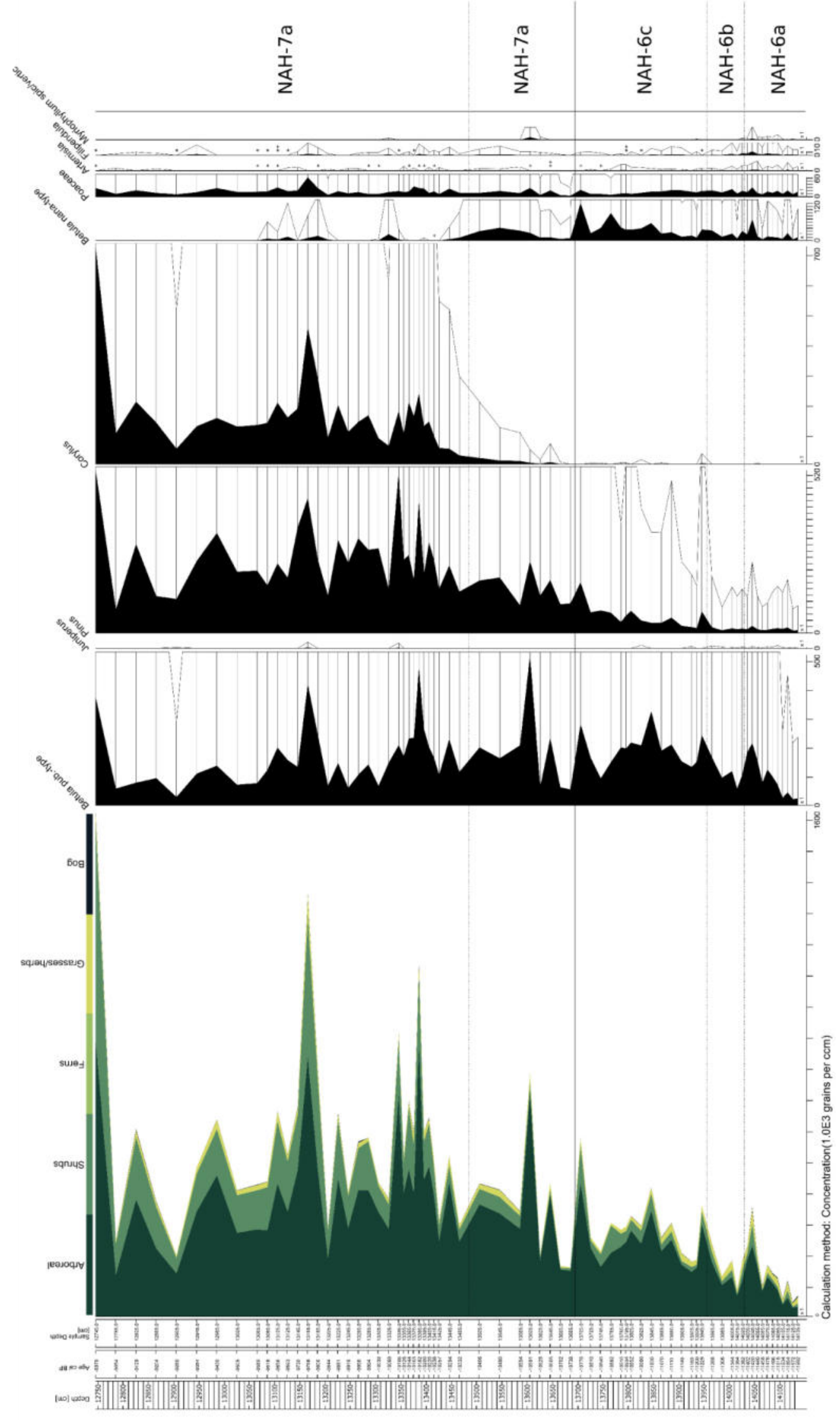


Figure 5:

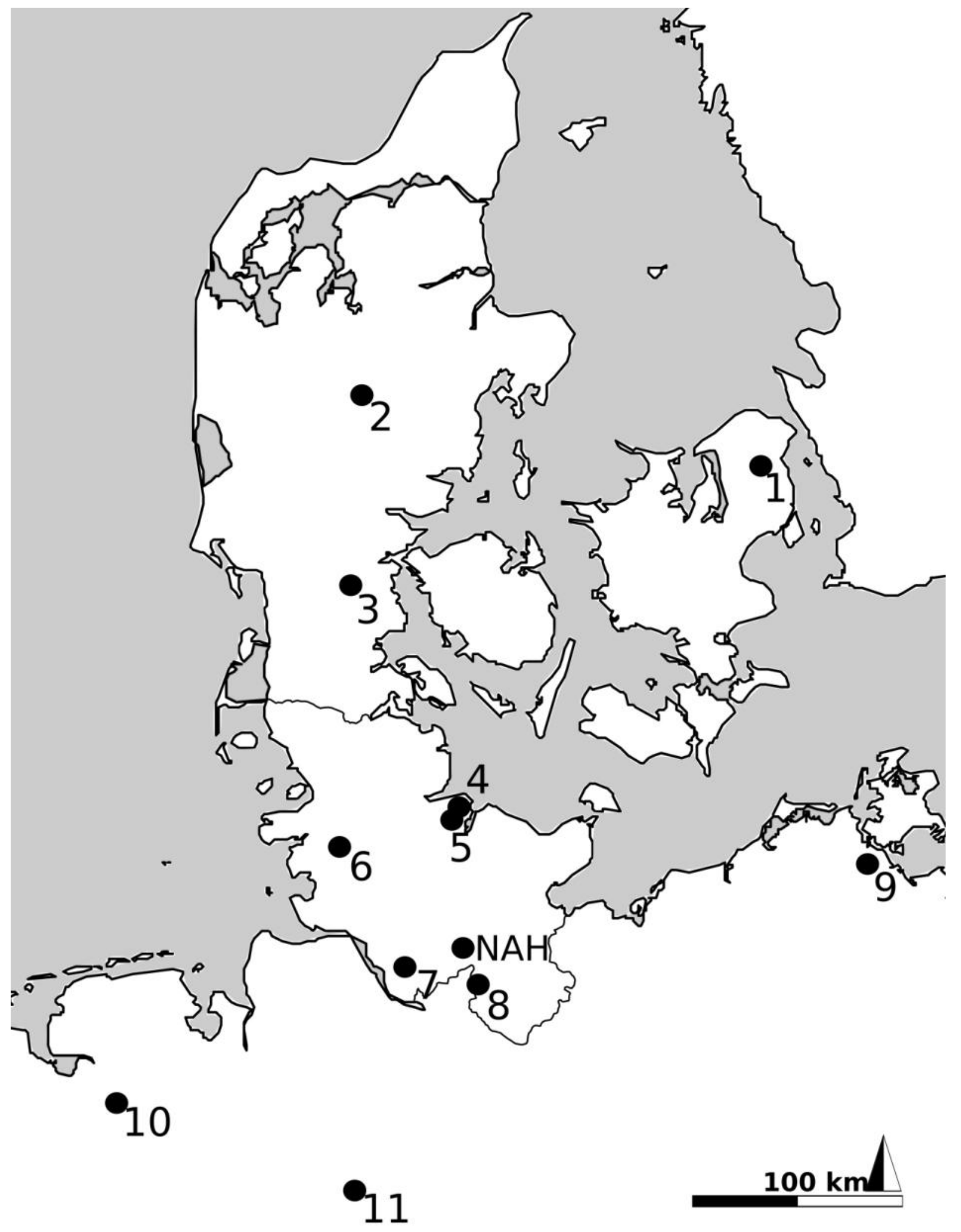


Figure 6a:

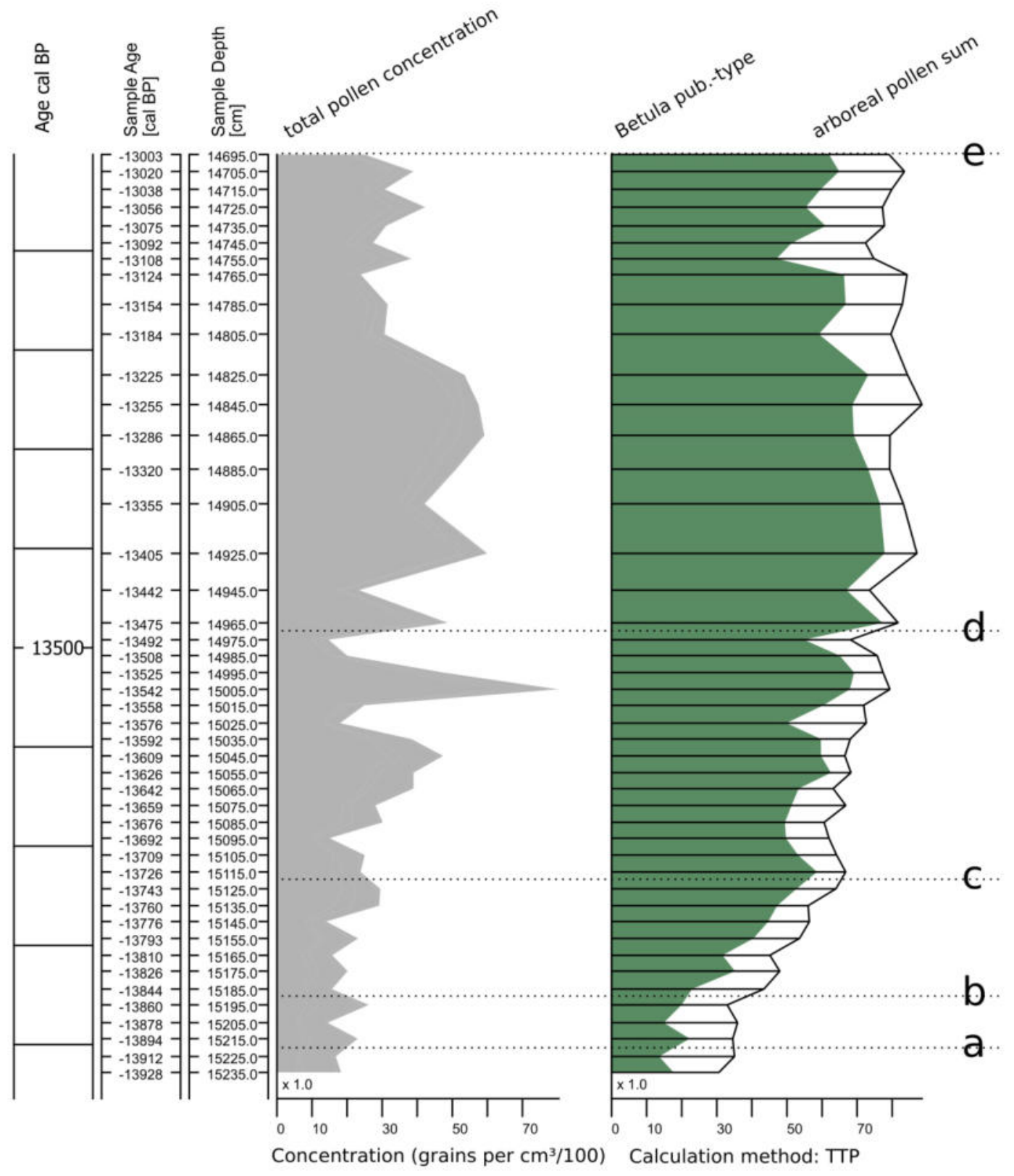


Figure 6b:

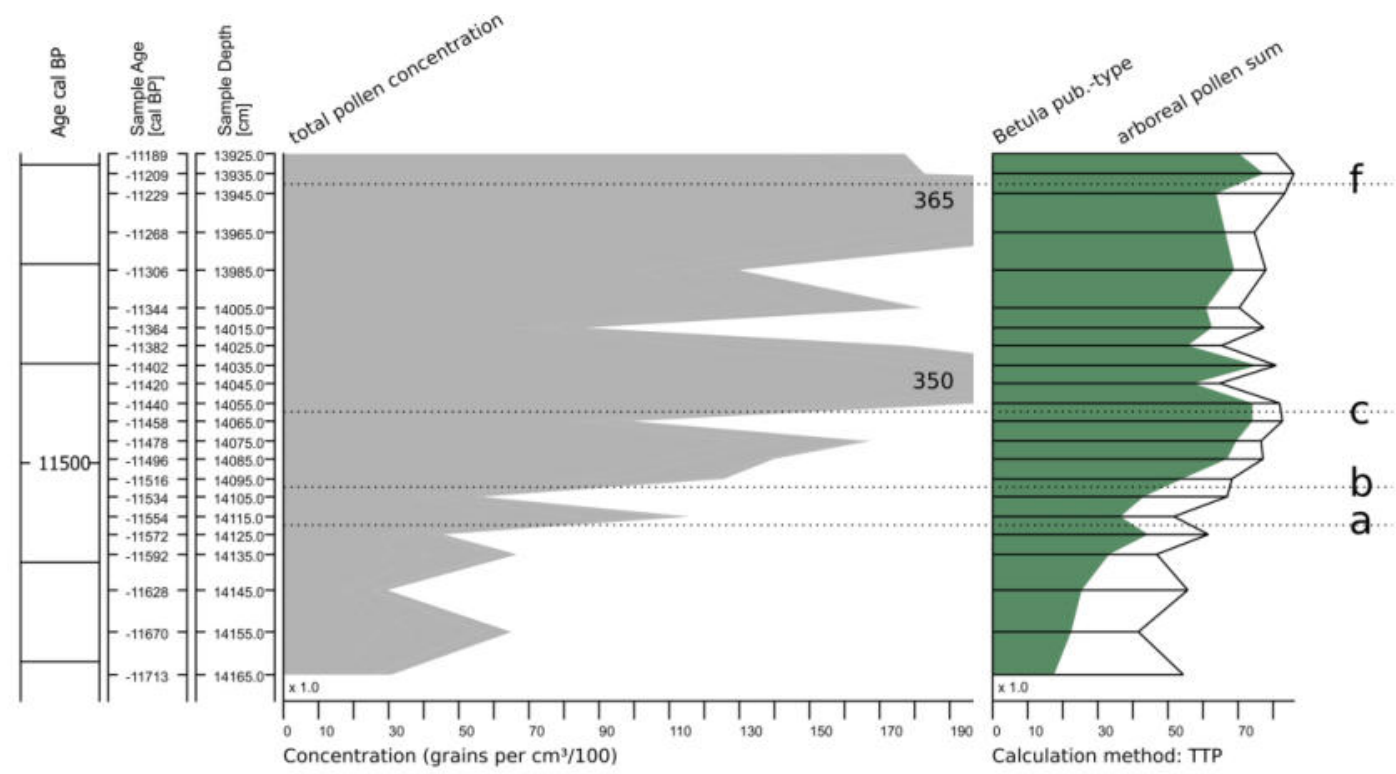

Figure 7:

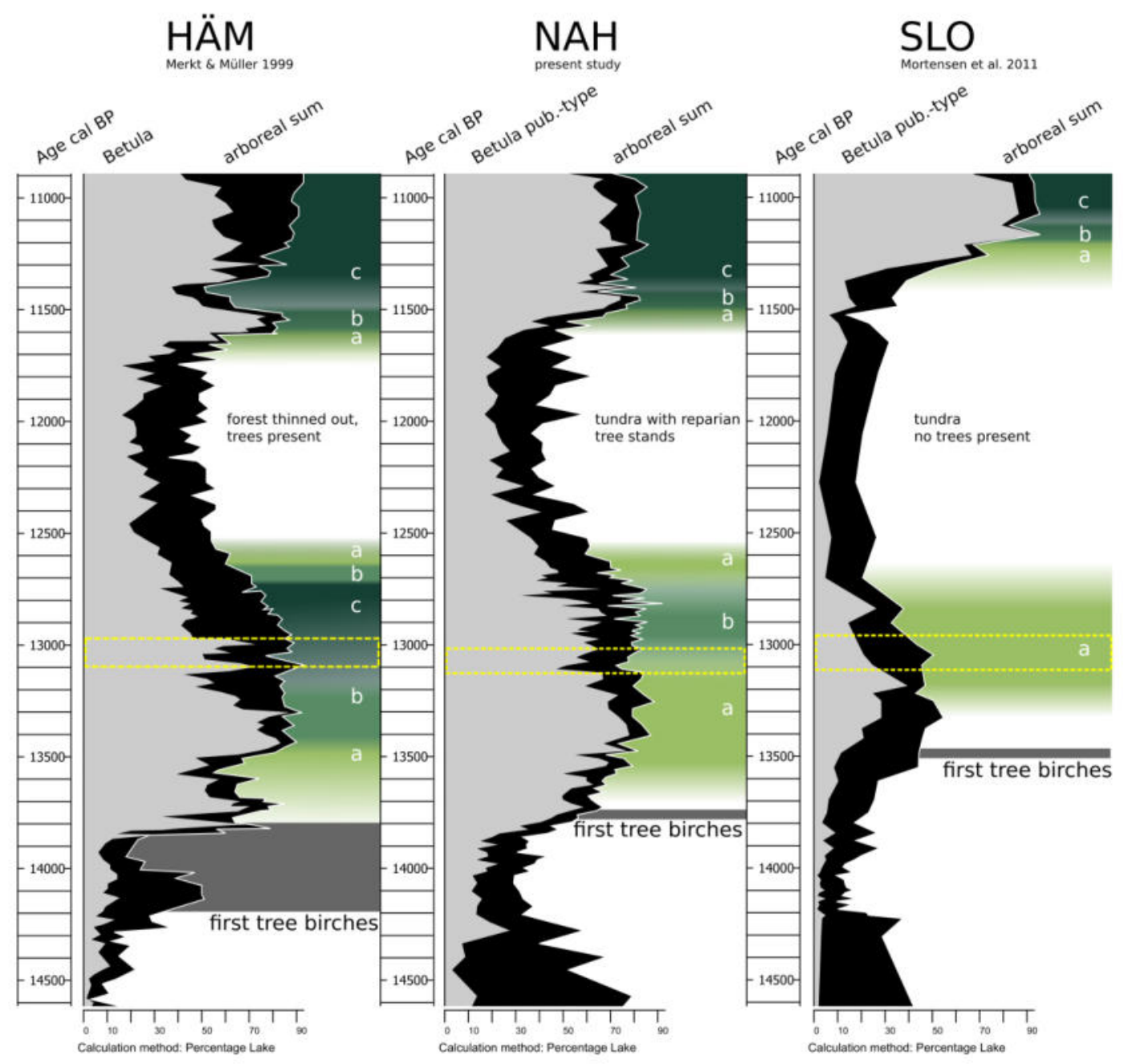




\section{Table captions:}

Table 1: overview on the chronological classification of pollen featured as mentioned in the text.

Table 2: overview on phases of vegetation development classified after biostratigraphic terminology as used in the present study

Table 3: overview on proxy data for the defined four phases of charcoal events

Table 1:

palynological feature

early Allerød period

early Preboreal period

(a) start of pre-woodland phase

$\sim 13,890$ cal yr BP

$\sim 11,520$ cal yr BP

(b) start of steep Betula-rise

$\sim 13,850$ cal yr BP

$\sim 11,550$ cal yr BP

(c) end of steep Betula-rise

$\sim 13,740$ cal yr BP

$\sim 11,450$ cal yr BP

(d) establishment of open woodland

$\sim 13,480$ cal yr BP

(undefined)

(e) establishment of dense woodland

$\sim 13,000$ cal yr BP

(undefined)

(f) establishment of forest

$\sim 11,250$

Table 2:

\begin{tabular}{lll}
\hline period // location HÄM NAH & SLO
\end{tabular}

Meiendorf

first tree birches

Dryas-1

Allerød 1

open woodland

first tree birches

Dryas-2/ Allerød 2

Allerød 3a forest

open woodland

first tree birches

GZO/ Allerød 3b

Allerød 3c-d

forest

dense woodland

open woodland

Dryas 3

Early Preboreal forest forest 
Table 3:

\begin{tabular}{lllll}
\hline & {$[1]$} & {$[2]$} & {$[3]$} & {$[4]$} \\
\hline charcoal size class $>50 \mu \mathrm{m}$ & $\mathrm{x}$ & $\mathrm{x}$ & $\mathrm{x}$ & $\mathrm{x}$ \\
charcoal size class $>100 \mu \mathrm{m}$ & $\mathrm{x}$ & $\mathrm{x}$ & $\mathrm{x}$ & $\mathrm{x}$ \\
vegetation response & $\mathrm{x}$ & & & \\
erosion indicator & & $\mathrm{x}$ & $\mathrm{x}$ & \\
synchr. Usselo horizons & $\mathrm{x}$ & $\mathrm{x}$ & & $\mathrm{x}$ \\
arch. finds & & $\mathrm{x}$ & $\mathrm{x}$ & $\mathrm{x}$ \\
arch. ${ }^{14} \mathrm{C}$ dates & & $\mathrm{x}$ &
\end{tabular}




\begin{tabular}{|c|c|c|c|c|}
\hline PAZ & $\begin{array}{l}\text { Depth ( } \mathrm{mm} \\
\text { below } \\
\text { surface) }\end{array}$ & Biozone NAH & $\begin{array}{l}\text { Common } \\
\text { classification }\end{array}$ & Description \\
\hline NAH-1 & $15.665-15.520$ & Pleniglacial & Pleniglacial & $\begin{array}{l}\text { Charcoal concentration, Dinoflaggelates (T_704) and redeposited taxa show values }>10 \%, \\
\text { Pinus values }>50 \% \text {. Betula pubescens-type values } \sim 10 \%, B \text {. nana-type, Pediastrum and } \\
\text { Botryococcus values } \lambda \text { towards upper boundary. Simultaneous minima visible in LOI } 550 \\
\text { and } 950 .\end{array}$ \\
\hline NAH-2a1 & $15.520-15.425$ & Meiendorf a1 & $\begin{array}{l}\text { Early } \\
\text { Meiendorf/ } \\
\text { Oldest Dryas } \\
\text { sensu Iversen }\end{array}$ & $\begin{array}{l}\text { Pinus values } \searrow \text {, Betula pubescens-type values } \nearrow \text { (> 10\%), Hippophaë starts and Artemisia } \\
\text { values } \nearrow>8 \%, \lambda \text { in Helianthemum, Bidens-type, Caryophyllaceae and Poaceae values. } \\
\text { Salix, Juniperus, Asteraceae and Selaginella present, Thalictrum values } \nearrow \text {. Filinia longiseta- } \\
\text { type (T_603) values } \nearrow \text { while Glomus (T_207) with maximum values. Two simultaneous } \\
\text { minima visible in LOI } 550 \text { and } 950 \text {. }\end{array}$ \\
\hline NAH-2a2 & $15.425-15.305$ & Meiendorf a2 & $\begin{array}{l}\text { Early } \\
\text { Meiendorf/ } \\
\text { Bølling sensu } \\
\text { Iversen }\end{array}$ & $\begin{array}{l}\text { Betula pubescens-type values } \rightarrow \text {, while Pinus values slowly } \searrow \text {. Hippophaë with maximum } \\
\text { values (>4\%) while Helianthemum and Poaceae } \nearrow \text {. Maxima in Plantago major/media and } \\
\text { Thalictrum values. Cyperaceae } \nearrow, \text { while Galium-type and Rosaceae start. Strong } \nearrow \text { in } \\
\text { Pediastrum values. Desmidiaceae (T_332), Filinia longiseta-type (T_603) and Glomus } \\
\text { (T_207) continuously present. Strong } \nearrow \text { in LOI } 550 \text { and } 950 .\end{array}$ \\
\hline NAH-2b & $15.305-15.240$ & Meiendorf b & $\begin{array}{l}\text { Late Meiendorf/ } \\
\text { Bølling sensu } \\
\text { Iversen }\end{array}$ & $\begin{array}{l}\text { Pinus and Betula pubescens-type values } \lambda \text {, second less pronounced maximum of } \\
\text { Hippophaë values, maximum Helianthemum }(>25 \%) \text { and Bidens-type }(\sim 3 \%) \text { values. } \\
\text { Poaceae and Artemisia values } \searrow \text {, Pediastrum with } \nearrow \text { values and slowly } \searrow \text { thereafter, LOI } \\
550 \text { and } 950 \text { values slowly } \lambda \text {. }\end{array}$ \\
\hline NAH-3 & $15.240-15.180$ & Dryas 1 & $\begin{array}{l}\text { Dryas } 1 / \\
\text { Older Dryas } \\
\text { sensu Iversen }\end{array}$ & $\begin{array}{l}\text { Pinus and Betula pubescens-type and B. nana-type values fluctuate strongly, maximum in } \\
\text { Poaceae (> 35\%) and Rumex acetosa-type values (> 2\%). Hippophaë values } \downarrow \text {. Second } \\
\text { Maximum in Helianthemum values ( 20\%) and Pediastrum with minimum values. Many } \\
\text { heliophilous steppe elements present. Slow } \searrow \text { in LOI } 550 \text { values and } \downarrow \text { in LOI } 950 \text { values. }\end{array}$ \\
\hline NAH-4a & $15.180-15.110$ & Allerød 1 & $\begin{array}{l}\text { Early Allerød / } \\
\text { Bølling sensu } \\
\text { Usinger }\end{array}$ & $\begin{array}{l}\text { Strong } \uparrow \text { and maximum of Betula pubescens-type values (> 58\%), B. nana-type values } \lambda \text {. } \\
\text { Poaceae, Helianthemum and Artemisia values } \searrow \text {. Hippophaë values slowly } \lambda \text {. LOI } 550 \\
\text { values } \lambda \text { and } 950 \text { values } \rightarrow \text {. }\end{array}$ \\
\hline NAH-4b & $15.110-15.050$ & $\begin{array}{l}\text { Allerød } 2 \text { / } \\
\text { Dryas } 2\end{array}$ & Dryas 2 & $\begin{array}{l}\text { Betula pubescens-type values } \searrow \text {, maximum Salix values }(>4 \%) \text { and Juniperus ( }>2 \%) \text { values. } \\
\text { Poaceae, Rumex acetos-type, Galium-type and Brassicaceae values } \lambda \text {, maximum } \\
\text { Cyperaceae values ( }>26 \% \text { ) and Thelictrum values ( }>4 \%) \text {. Botryococcus, Pediastrum, and }\end{array}$ \\
\hline
\end{tabular}




\begin{tabular}{|c|c|c|c|c|}
\hline & & & & $\begin{array}{l}\text { Spirogyra (T_131) values } \lambda, \text { maximum Filinia longiset-type (T_603) values }(>2 \%) \text {. } \\
\text { Desmidiaceae (T_332) and Dinoflaggelate (T_704) values } \searrow \text {. LOI } 550 \text { and } 950 \text { values } \lambda \text {. }\end{array}$ \\
\hline NAH-4c1 & $15.050-14.760$ & Allerød 3a & Allerød & $\begin{array}{l}\text { Betula pubescens-type values slowly } \lambda \text { to Lateglacial maximum (> 77\%). Salix and B. nana- } \\
\text { type values } \rightarrow \text {, Pinus values slowly } \lambda \text { towards upper boundary. Poaceae, Helianthemum } \\
\text { and many heliophilous taxa values } \searrow \text {. Cyperaceae and Botryococcus values } \searrow \text {. LOI } 550 \\
\text { values } \lambda \text { whereas } 950 \text { values } \searrow \text {. }\end{array}$ \\
\hline NAH-4c2 & $14.760-14.710$ & $\begin{array}{l}\text { Allerød 3b / } \\
\text { Gerzensee-Osc. }\end{array}$ & $\begin{array}{l}\text { Gerzensee- } \\
\text { Oscillation }\end{array}$ & $\begin{array}{l}\text { Pinus values } \lambda \text { and slowly } \searrow \text { towards upper boundary. Betula pubescens-type values } \downarrow \\
\text { and slowly } \lambda \text { towards upper boundary. B. nana-type, Artemisia, Thalictrum, Filipendula } \\
\text { and Cyperaceae values } \lambda \text {. Pediastrum values } \searrow \text { and LOI } 950 \text { values } \downarrow \text {. }\end{array}$ \\
\hline NAH-4c3 & $14.710-14.570$ & Allerød 3c & Late Allerød & $\begin{array}{l}\text { Pinus and Betula pubescens-type values strongly fluctuating, } B \text {. nana-type values } \lambda \\
\text { towards upper boundary. Juniperus and Filipendula values } \lambda \text {. LOI } 550 \text { values } \searrow \text { and } 950 \\
\text { values } \lambda \text {. }\end{array}$ \\
\hline NAH-4c4 & $14.570-14.370$ & Allerød 3d & Late Allerød & $\begin{array}{l}\text { Pinus values } \lambda \text { to maximum (>40\%) and } \searrow \text { towards upper boundary. Betula pubescens- } \\
\text { type } \searrow \text { towards upper boundary with corresponding steep decrease to Pinus maximum } \\
\text { values. Salix, Poaceae, Artemisia and Chenopodiaceae values } \lambda \text {. Cyperaceae values with } \\
\text { second maximum ( }>21 \%) \text {. Menyanthes trifoliata and Equisetum values } \lambda, \text { Empetrum and } \\
\text { Botryococcus } \lambda \text { towards upper boundary. Spirogyra (T_131) and cluster of globose fungal } \\
\text { cells (T_200) present. LOI } 950 \text { values } \lambda \text { to maximum }(>21 \%) \text { and } \downarrow \text { towards upper } \\
\text { boundary. }\end{array}$ \\
\hline NAH-5a & $14.370-14.240$ & Dryas 3 a & $\begin{array}{l}\text { Early Younger } \\
\text { Dryas }\end{array}$ & $\begin{array}{l}\text { Betula pubescens-type values } \searrow, B \text {. nana-type, Poaceae and Artemisia values } \lambda \text { while } \\
\text { numerous heliophilous taxa are continuously present (Helianthemum, Rumex acetosa- } \\
\text { type, Ranunculus acris-type, Bidens-type, Caryophyllaceae and Asteraceae). Filipendula } \\
\text { and Cyperaceae values } \searrow \text { while Empetrum values } \lambda \text {. Botryococcus with maximum values } \\
\text { (>18\%) and slowly } \searrow \text { thereafter. Botryococcus maximum values correspond to minimum } \\
\text { values of Pediastrum. After that, Pediastrum values } \uparrow \text {. Continuous presence of Glomus } \\
\text { (T_207), Filinia longiseta-type (T-603) and Dinoflaggelates (T_704). Desmidiaceae (T_332) } \\
\text { with maximum values (>2\%). LOI } 550 \text { values } \searrow \text { while } 950 \text { values } \downarrow \text { below } 2 \% \text { and } \rightarrow \text {. }\end{array}$ \\
\hline NAH-5b & $14.240-14.140$ & Dryas $3 \mathrm{~b}$ & $\begin{array}{l}\text { Late Younger } \\
\text { Dryas }\end{array}$ & $\begin{array}{l}\text { Pinus values } \lambda, \text { Betula nana-type and Artemisia values slowly } \searrow \text {. Maximum in Empetrum } \\
\text { values }(>16 \%) \text { and Pediastrum values (> 79\%). Juniperus continuously present. LOI } 500 \\
\text { values } \lambda \text { while } 950 \text { values } \rightarrow \text {. }\end{array}$ \\
\hline NAH-6a & $14.140-14.030$ & Preboreal a & Early Preboreal & $\begin{array}{l}\text { Betula pubescens-type values } \uparrow \text { to early Holocene maximum (73\%). Filipendula } \nearrow \text { to } \\
\text { maximum values ( }>4 \% \text { ). Pinus, B. nana-type, Poaceae and Artemisia values } \searrow \text {. Many } \\
\text { heliophilous taxa (Helianthemum, Rumex acetosa-type, Ranunculus acris-type, Bidens- }\end{array}$ \\
\hline
\end{tabular}




\begin{tabular}{|c|c|c|c|c|}
\hline & & & & $\begin{array}{l}\text { type, Caryophyllaceae and Asteraceae) } \downarrow \text {. Cyperaceae, Empetrum and Pediastrum values } \\
\text { У. Typha latifolia, Equisetum and Myriophyllum spic./vert. values } \lambda \text {. LOI } 550 \text { values } \lambda \text { and } \\
950 \text { values } \uparrow \text {. }\end{array}$ \\
\hline NAH-6b & $14.030-13.955$ & $\begin{array}{l}\text { Preboreal b / } \\
\text { PBO }\end{array}$ & $\begin{array}{l}\text { Preboreal- } \\
\text { Oscillarion }\end{array}$ & $\begin{array}{l}\text { Pinus, Salix, Populus and Poaceae values } \lambda \text { while Betula pubescens-type, Artemisia and } \\
\text { Filipendula values } \searrow \text {. Equisetum with maximum values }(>2 \%) \text { while Typha latifolia and } \\
\text { Myriophyllum spic./vert. values } \downarrow \text {. Filinia longiseta-type (T_603) continuously present. LOI } \\
550 \text { values } \lambda \text { and } 950 \text { values } \rightarrow \text {. }\end{array}$ \\
\hline NAH-6c & 13.955-13.695 & Preboreal c & Late Preboreal & $\begin{array}{l}\text { Betula pubescens-type again with Holocene maximum values (>73\%) and slowly } \searrow \text { while } \\
\text { Pinus values } \lambda \text { towards upper boundary. B. nana-type with Holocene maximum values (> } \\
29 \% \text { ) towards upper boundary. Populus with maximum values ( } 1 \%) \text {. Cyperaceae and } \\
\text { Pediastrum values } \searrow \text { while Monolete fern spore values } \lambda \text { and Nymphaea reaches } \\
\text { maximum values }(>1 \%) \text {. LOI } 550 \text { with maximum }(>27 \%) \text { while LOI } 950 \text { values strongly } \\
\text { fluctuate including further minimum values. }\end{array}$ \\
\hline NAH-7a & $13.695-13.485$ & Boreal a & Early Boreal & $\begin{array}{l}\text { Corylus continuously present and values } \lambda \text { towards upper boundary. Pinus with Holocene } \\
\text { maximum values ( }>60 \% \text { ) and } \searrow \text { towards upper boundary. Betula pubescens-type values } \\
\text { strongly fluctuating. B. nana-type values } \searrow \text {. Ulmus continuously present. LOI } 550 \text { values } \\
\text { with minor and } 950 \text { with major fluctuations. }\end{array}$ \\
\hline NAH-7b & $13.485-12.740$ & Boreal b & Mid Boreal & $\begin{array}{l}\text { Corylus values } \uparrow, \text { while Pinus values } \rightarrow \text { and Betula pubescens-type values } \searrow \text {. B. nana-type } \\
\text { values } \downarrow \text {. Ulmus and Quercus continuously present and values } \lambda \text {. Thermophilous taxa and } \\
\text { Filinia longiseta-type (T_603) continuously present. LOI } 550 \text { and } 950 \text { values } \rightarrow \text { with only } \\
\text { minor fluctuations. }\end{array}$ \\
\hline
\end{tabular}

Arrows indicate curve characteristics in comparison to previous assemblage zone. 


\begin{tabular}{|c|c|c|c|c|c|c|c|c|c|c|c|}
\hline $\begin{array}{l}\frac{5}{1} \\
\frac{0}{d} \\
0\end{array}$ & 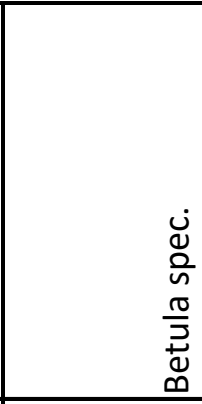 & 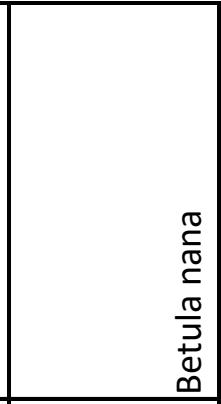 & 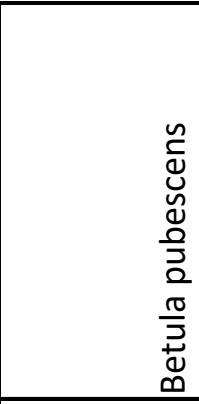 & 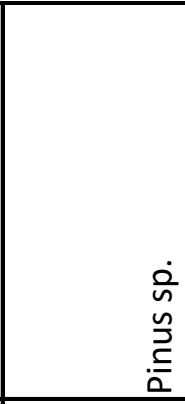 & $\begin{array}{l}\frac{n}{3} \\
\frac{0}{0} \\
2\end{array}$ & $\begin{array}{l}\frac{n}{L} \\
\frac{\pi}{0} \\
\frac{0}{\alpha} \\
. \frac{x}{\pi} \\
\tilde{n}\end{array}$ & $\begin{array}{l}\dot{0} \\
\hat{n} \\
\times \\
\dot{0} \\
\dot{U}\end{array}$ & 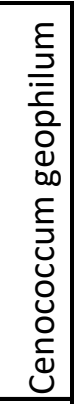 & 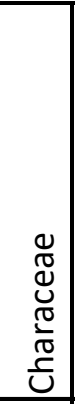 & $\begin{array}{l}\ulcorner \\
0 \\
0 \\
0 \\
0 \\
0 \\
\frac{1}{0} \\
0 \\
0 \\
0\end{array}$ & $\frac{1}{2}$ \\
\hline & & & & & & & & & & & \\
\hline 13165 & & & fruit scale & & & & & & & & $7 b$ \\
\hline 13245 & & & & periderm & & & & & & & $7 b$ \\
\hline 13625 & & & & periderm & & & & & & & $7 a$ \\
\hline 13805 & fruit scale & & & & & & & & & & $6 c$ \\
\hline 13965 & & & nutlet & & & & & & & & $6 b$ \\
\hline 14125 & & & & & & & 1 & & & & $6 a$ \\
\hline 14145 & fruit scale & & & & & & & 20 & 1 & & $5 b$ \\
\hline 14195 & & $\begin{array}{l}\text { fruit scale } \\
\text { and nutlet }\end{array}$ & & & & & & & & & $5 b$ \\
\hline 14215 & & & & & & & & 14 & & & $5 b$ \\
\hline 14220 & & & & & $\begin{array}{l}\text { wood } \\
\text { fragment }\end{array}$ & & & & & & $5 b$ \\
\hline 14235 & & & & & & & 1 & & & & $5 b$ \\
\hline 14275 & fruit scale & & & & & & & 7 & 1 & & $5 a$ \\
\hline 14305 & & & & & & & & 2 & & & $5 a$ \\
\hline 14315 & & & & & & & & 4 & & & $5 a$ \\
\hline 14335 & $\begin{array}{l}1 \text { nutlet/ } 3 \\
\text { fruit scales }\end{array}$ & & & & & & & & & & $5 a$ \\
\hline 14345 & & & & & & & & 2 & & & $5 a$ \\
\hline 14375 & & & & & & leaf & & & & & $4 c 4$ \\
\hline 14545 & & fruit scale & & & & & & & & & $4 c 4$ \\
\hline 14695 & & & & & & & & 2 & & & $4 c 3$ \\
\hline 14865 & fruit scale & & & & & & & & & & $4 c 1$ \\
\hline 14905 & fruit scale & & & & & & & & & & $4 \mathrm{c} 1$ \\
\hline 14945 & 2 fruit & & & & & & & & & & $4 c 1$ \\
\hline 14975 & & $\begin{array}{l}\text { fruit scale } \\
\text { and nutlet }\end{array}$ & & & & & & & & & $4 c 1$ \\
\hline 14995 & & & nutlet & & & & & & & & $4 c 1$ \\
\hline 15005 & fruit scale & & & & & & & & & & $4 \mathrm{c} 1$ \\
\hline 15025 & & fruit scale & & & & & & & & & $4 \mathrm{c} 1$ \\
\hline 15045 & & & & & & & & 3 & & & $4 \mathrm{c} 1$ \\
\hline 15145 & & & nutlet & & & & & & & & $4 a$ \\
\hline 15185 & & & & & & & & & & 1 & 3 \\
\hline 15495 & & & & & & leaf & & & & & $2 a 1$ \\
\hline
\end{tabular}

